Florida International University

FIU Digital Commons

FIU Electronic Theses and Dissertations

University Graduate School

7-11-2012

\title{
Sediment Yield Modeling and Identification of Erosion Hotspots in Tropical Watersheds: The Case of Upper Ruvu Catchment in Tanzania
}

Juliana J. Msaghaa

Florida International University, jmsag001@fiu.edu

DOI: $10.25148 /$ etd.FI12080633

Follow this and additional works at: https://digitalcommons.fiu.edu/etd

\section{Recommended Citation}

Msaghaa, Juliana J., "Sediment Yield Modeling and Identification of Erosion Hotspots in Tropical Watersheds: The Case of Upper Ruvu Catchment in Tanzania" (2012). FIU Electronic Theses and Dissertations. 707.

https://digitalcommons.fiu.edu/etd/707 


\section{FLORIDA INTERNATIONAL UNIVERSITY}

Miami, Florida

\section{SEDIMENT YIELD MODELING AND IDENTIFICATION OF EROSION HOTSPOTS IN TROPICAL WATERSHEDS: THE CASE OF THE UPPER RUVU CATCHMENT \\ IN TANZANIA}

A thesis submitted in partial fulfillment of

the requirements for the degree of

MASTER OF SCIENCE

in

ENVIRONMENTAL STUDIES

by

Juliana J. Msaghaa 


\title{
To: Dean Kenneth G. Furton College of Arts and Sciences
}

This thesis, written by Juliana J. Msaghaa, and entitled: Sediment Yield Modeling and Identification of Erosion Hotspots in Tropical Watersheds; The Case of the Upper Ruvu Catchment, Tanzania, having been approved in respect to style and intellectual content, is referred to you for judgment.

We have read this thesis and recommend that it be approved.

\author{
Mahadev Bhat \\ Krishnaswamy Jayachandran, Co-Major Professor
}

Date of Defense: July 11, 2012

Assefa M. Melesse, Co-Major Professor

The thesis of Juliana J. Msaghaa is approved.

Dean Kenneth G. Furton

College of Arts and Sciences

Dean Lakshmi N. Reddi

University Graduate school

Florida International University, 2012 


\section{DEDICATION}

To my parents, especially my mother Elizabeth Singibara and family for their encouragement and support in the hard time of this study.

"May the soul of my lovely father Mr. James N. Msaghaa attain everlasting life and rest in Harmony. Amen" 


\section{ACKNOWLEDGMENTS}

I would like to express my sincere acknowledgement to members of my committee; Dr. Assefa M. Melesse, Dr. Mahadev Bhat and Dr. Krishnaswamy Jayachadran for their guidance, encouragement, advice and support. Their suggestions and comments before and after undertaking this research considered valuable towards my professional career. I am grateful to my advisor Dr. Melesse for accepting me to be under his supervision through creating base of this research by providing moral support and encouragement until compilation of this study. I would like to take this opportunity to thank the United States Agency for International Development (USAID)/Tanzania for awarding me the scholarship under the Leadership Training Program-LTP given to study in the USA, particularly at Florida International University (FIU).

I would like to thank Dr. Leonard Scinto (Florida International University), Dr

Pro. Pius Z. Yanda, Director/Chairman, Institute of Resource Assessment, University of Dar es salaam -Tanzania, for their feedback, direction, and assistance when I needed it. Also, I would like to extend my special thanks to Pro. Balthazar Msanya and Dr. Consolatha Mhaiki from Sokoine University of Agriculture-Tanzania for their groundwork, cooperation and assistance during my field work research.

A special word of gratitude is to the Tanzania Integrated Water, Sanitation and Hygiene (iWASH) Program, Wami-Ruvu basin/Tanzania and Morogoro District Council/Tanzania for their support of using their office equipment and technical assistance during site selection as well as data collection during the entire study period. 
My sincere thanks also goes to my colleagues: Mengistu Defersha, Shimelis Setegn, Diana Johnson, George Atisa, Hari Kandel, Shimelis Dessu and Evan Cook who directly or indirectly contributed for the success of my thesis work. I thank Simelis Dessu for the advice he made which helped me to be stronger and read a variety of different materials. Fukhrudin Khalif deserves special thanks for going through my work and my methodology and for the discussion we had while I was a student. The valuable ideas he provided me during the conception period of the research and for his unending technical support during this work. The overwhelming cooperation and assistance received from all the staff members and students of Florida International University, Department of Earth and Environment who directly or indirectly lent their time during the study period cannot be forgotten.

Finally, special recognition goes out to my family, for their support, encouragement and patience during my study. Special thanks to my husband, Mr. Kilongo M.I who inspired me by providing constant challenges and encouragement during the entire process. To my lovely sons Said C.N. Kilongo and Isaac C.N. Kilongo, beautiful daughter Sabrina C.K. Kilongo, who missed out on a lot of Mom's time while I sought intellectual enlightenment. I thank you for your patience and love you more than you will ever know.

Above all loving kindness and faithfulness of the Almighty God in supplying health, endurance, and protection throughout the study is gratefully appreciated. 


\begin{abstract}
OF THE THESIS
SEDIMENT YIELD MODELING AND IDENTIFICATION OF EROSION HOTSPOTS

IN TROPICAL WATERSHEDS: THE CASE OF UPPER RUVU CATCHMENT IN
\end{abstract}

TANZANIA

by

Juliana J Msaghaa

Florida International University, 2012

Miami, Florida

Professor Krishnaswamy Jayachandran, Co-Major Professor

Professor Assefa M. Melesse, Co-Major Professor

The main objective of this study was to test the sediment prediction capability of the Water Erosion Prediction Project (WEPP) model on tropical watersheds and also identify erosion hotspot areas. The maximum total discharge at the watershed outlet was $3,462 \mathrm{~m}^{3} / \mathrm{s}$. Runoff also varied with soil type in all four watersheds. The highest average annual runoff depths occurred on areas with high percentage of ferralic cambisols and humic acrisols soils. The lowest runoff depth was in areas with high percentage of rhodic ferralsols and eutric leptosols soils in Kibungo chini. The soil loss and sediment yield had the same relationship as the runoff changes. The highest and lowest total average annual soil loss rate was estimated in Mfizigo juu and Kibungo chini respectively. The cultivated land contributed to over $81 \%$ of soil loss and $86 \%$ of sediment yield in all four scenarios. The overall spatial results maps indicated WEPP model can help managers to implement necessary precaution measures to prevent sediment yield and soil erosion. 


\section{TABLE OF CONTENTS}

CHAPTER

PAGE

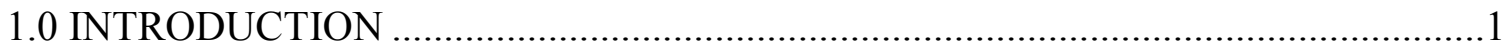

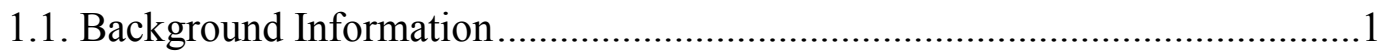

1.2. Statement of the Problem.......................................................................... 3

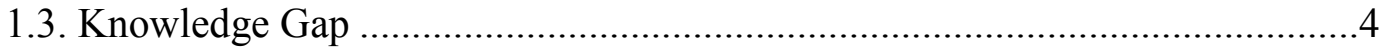

1.4. Justification of the Study ...........................................................................

1.5. Research Objectives and Questions ......................................................

1.5.1. Research Questions .............................................................. 7

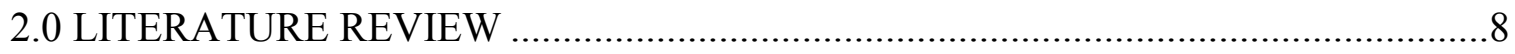

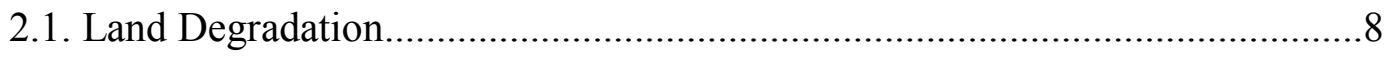

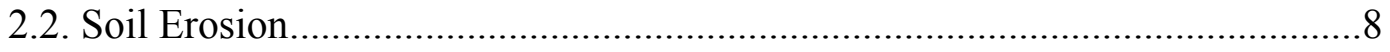

2.3. Factors Influencing Water Soil Erosion.................................................. 10

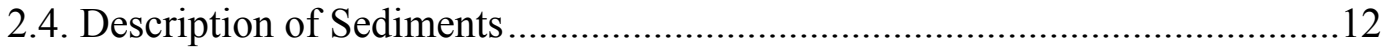

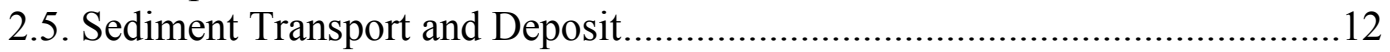

2.6. Sediment Load and Sediment Yield ......................................................... 13

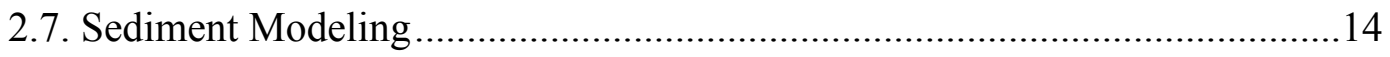

2.8. Universal Soil Loss Equation (USLE/RUSLE) ......................................... 17

2.9. Water Erosion Prediction Project (WEPP) .............................................. 17

2.9.1. Surface Hydrology ................................................................. 19

2.9.2. Hillislope Erosion .................................................................22

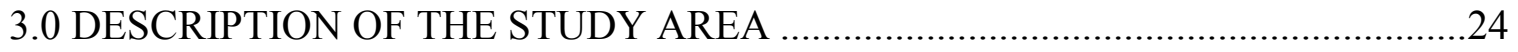

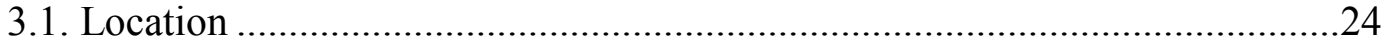

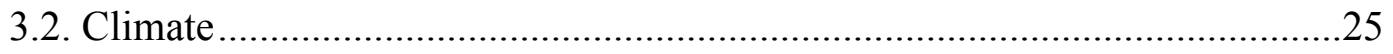

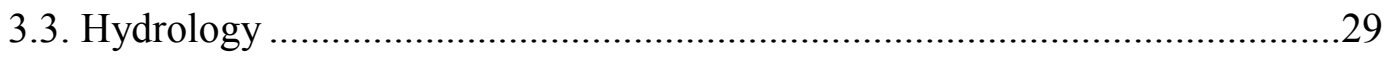

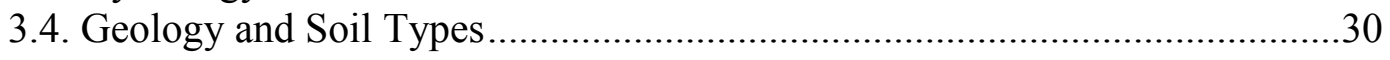

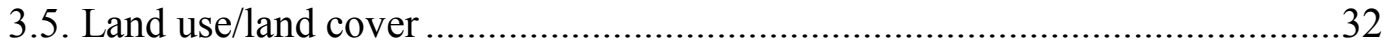

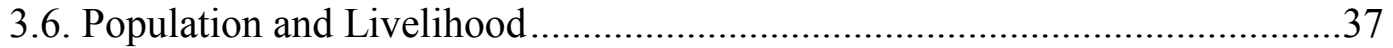

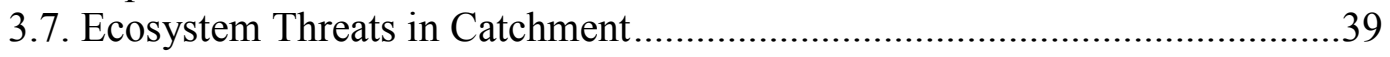

3.8. Water Quality Management .......................................................... 40

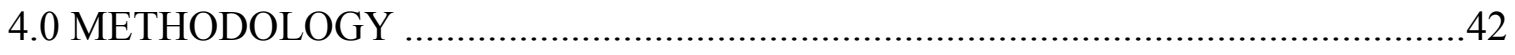

4.1. GIS and WEPP Modeling procedures..................................................4 42

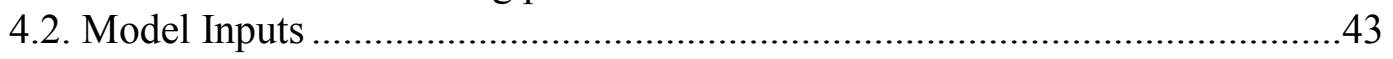

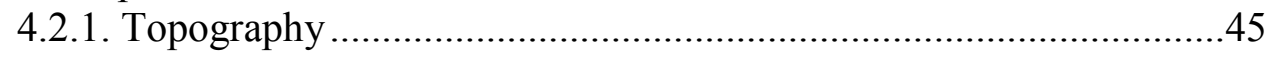

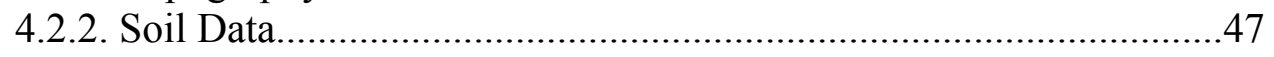

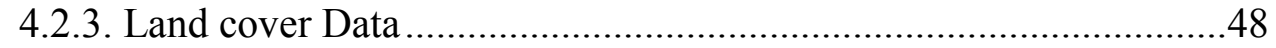

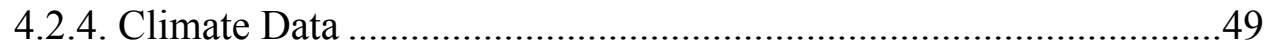

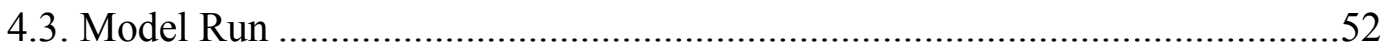

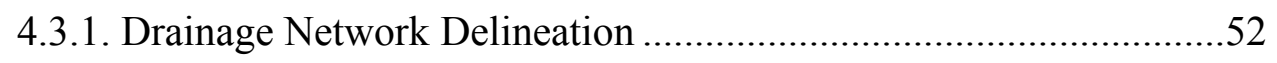

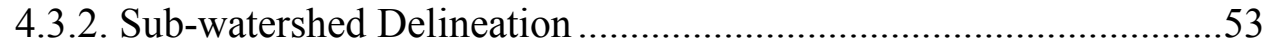




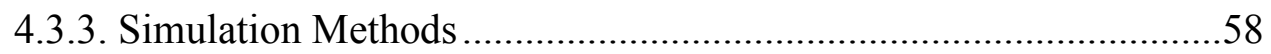

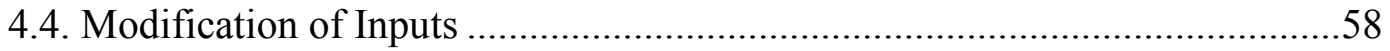

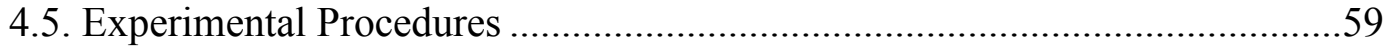

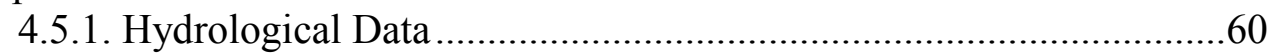

4.5.2. Suspended Sediment Load ........................................................62

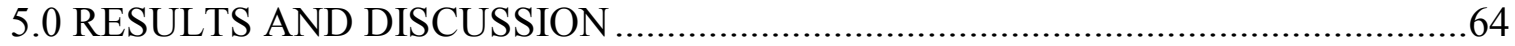

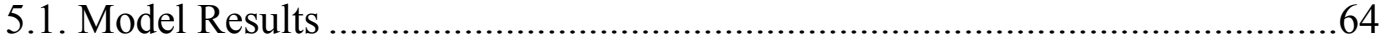

5.1.1. Average Annual Runoff .............................................................64

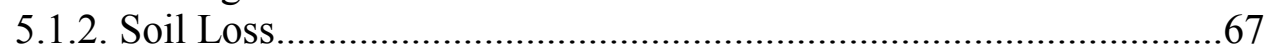

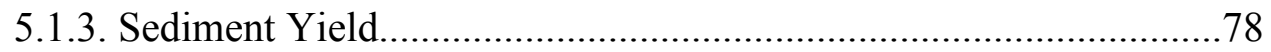

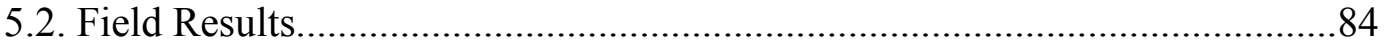

5.2.1. Total Suspended Solids and Average Annual Runoff ....................84

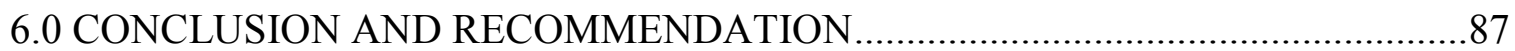

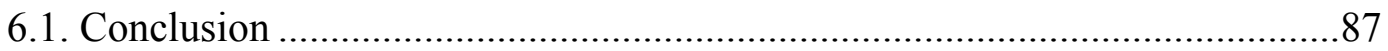

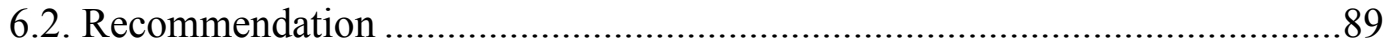

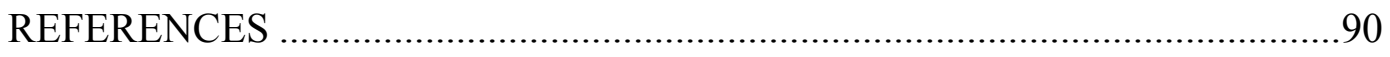

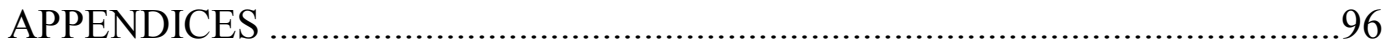




\section{LIST OF TABLES}

TABLE

PAGE

Table 2.1. Types of Sediment models and their inputs requirements ............................16

Table 3.1. Lists of Weather stations selected with available data ................................26

Table 3.2. Major Soil Types, Particle size distribution and their area coverage in upper

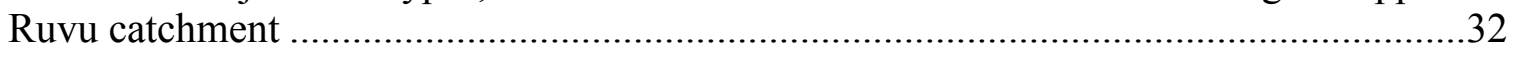

Table 3.3. Periodic Land use/land cover changes percentage in upper Ruvu catchment ..34

Table 4.1. Soil text files for soil types and properties for WEPP model .........................48

Table 4.2. Land use/land cover and Management text files for WEPP model .................49

Table 4.3. Average monthly rainfall (inches) for PRISM modification model ................50

Table 4.4. Modification of model input parameters for different

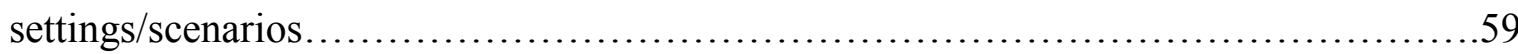

Table 5.1. Summary of variation in soil loss and sediment yield with landuse/land cover

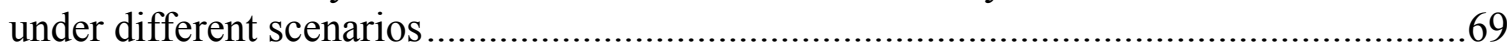

Table 5.2. Sediment particle information leaving channel at Kibungo watershed ............74

Table 5.3. Distribution of primary particles and organic matter in Kibungo watershed

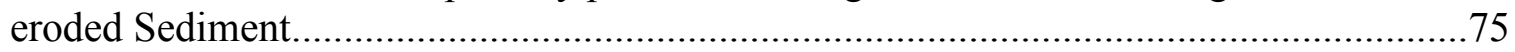




\section{LIST OF FIGURES}

FIGURE

PAGE

Figure 2.1. Factors affecting soil erosion by water .............................................. 11

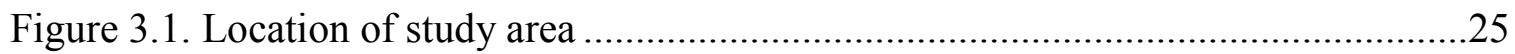

Figure 3.2. Rainfall variation in the upper Ruvu catchment as recorded in eight weather

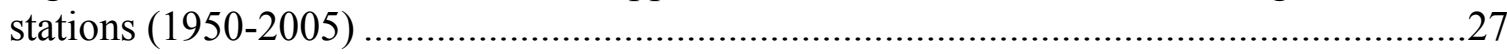

Figure 3.3. Rainfall variation with elevation: Upstream and Downstream of the upper

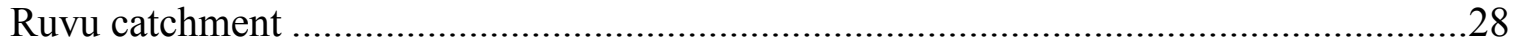

Figure 3.4. 55 -year average annual rainfall variation within selected weather stations ..28

Figure 3.5. Ruvu River at Kibungo bridge during dry season (a) Upstream (b)

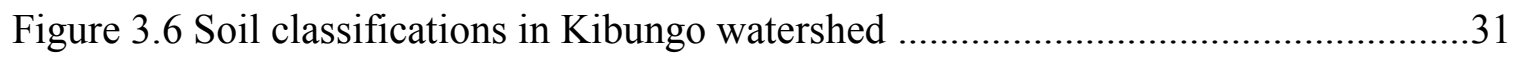

Figure 3.7. Land use changes classification in the upper Ruvu catchment .....................33

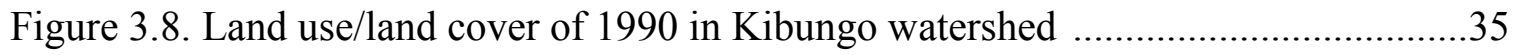

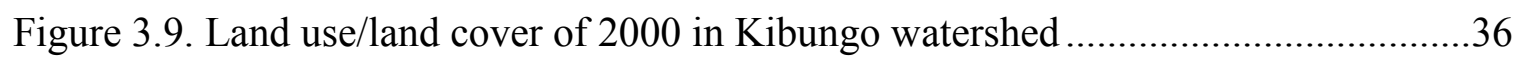

Figure 3.10. Population variation in upland wards within Kibungo watershed.................37

Figure 3.11. Villages' settlement increase towards high elevation ...............................38

Figure 4.1. Flow chart of WEPP model simulation ................................................44

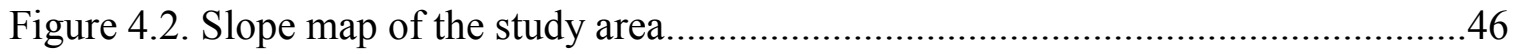

Figure 4.3. Print screens shows the text bridges for the soils data ..............................47

Figure 4.4. Print screens shows the text bridges for the land use/land cover data............49

Figure 4.5. WEPP model climate data modification window at Rock climate Interface ..51

Figure 4.6. Mfizigo sub-watershed delineated by WEPP model ...................................54

Figure 4.7. Mvuha sub-watershed delineated by WEPP model.......................................55 
Figure 4.8. Msumbizi sub-watershed delineated by WEPP model.

Figure 4.9. Kibungo sub-watershed delineated by WEPP model ..................................57

Figure 4.10. Soil coverage variation for Upland land slope and lowland slope ...............59

Figure 4.11. D-48 and D-74 sediment sampler used during field research ....................61

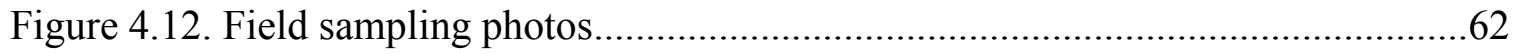

Figure 5.1. Average annual runoff variations within the sub-watersheds as estimated by model

Figure 5.2. Average discharge volume variations within the sub-watersheds as estimated by model.

Figure 5.3. Land use/ land cover in Kibungo watershed as delineated by WEPP model..69

Figure 5.4. Variations of soil loss, sediment yield and runoff with land use/land cover under scenario 1 in steep slope area as estimated by the model

Figure 5.5. Variations of soil loss, sediment yield and runoff with land use/land cover under scenario 2 in steep slope area as estimated by the model

Figure 5.6. Variations of soil loss, sediment yield and runoff with land use/land cover under scenario 3 in low land slope area estimated by the model.

Figure 5.7. Variations of soil loss, sediment yield and runoff with land use/land cover under scenario 4 in low land slope area as estimated by the model

Figure 5.8. Variations of soil loss and sediment yield with landuse/land cover in Kibungo watershed

Figure 5.9. Variations of soil loss, yield and runoff with soil type in steep slope area as estimated by the model

Figure 5.10. Variations of soil loss, sediment yield and runoff with soil type in low land

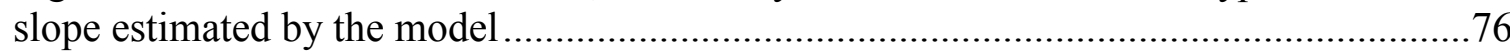

Figure 5.11. Variations of runoff with soil type as estimated by the model.....................77

Figure 5.12. Variations of Soil loss with soil type as estimated by the model .................77

Figure 5.13. Variations of Sediment yield with soil type as estimated by the model........78 
Figure 5.14. Map of average annual sediment yield for Mfizigo sub-watershed

Figure 5.15. Map of average annual sediment yield for Mvuha sub-watershed ...............81

Figure 5.16. Map of average annual sediment yield for Msumbizi sub-watershed ...........82

Figure 5.17. Map of average annual sediment yield for Kibungo Chini sub-watershed ...83

Figure 5.18. Selected spatial sediment sampling locations at upper Ruvu catchment ......84

Figure 5.19. Sediments load and flows in the upper Ruvu catchment ...........................85

Figure 5.20. Sediments load and flows relationship in the upper Ruvu catchment .........85 


\section{LIST OF ABBREVIATIONS AND ACRONYMS}

AGNPS

AGWA

ANSWERS

BPCDG

CLIGEN

CREAMS

CSA

DEM

DFT

EIA

EPWS

FAO

GIS

GPS

HWSD

IRA

IWRM

JICA

LESAM

MSCL
Agricultural Non-Point Source Pollution Model

Automated Geospatial Watershed Assessment Tool

Areal Nonpoint Source Watershed Environment Response

Simulation

Breakpoint Climate Data Generator

World Climate Generator

Chemicals, Runoff and Erosion from Agriculture Management System

Critical Source Area

Digital Elevation Model

District Facilitation Team

Environmental Impact Assessment

Equitable Payment for Water Resources

Food and Agriculture Organization

Geographical Information System

Geographical Position System

Harmonized World Soil Database

Institute of Natural Resources

Integrated Water Resources Management

Japan International Cooperation Agency

Landscape-based Environmental System Analysis \& Modeling

Minimum Source Channel Length 


$\begin{array}{ll}\text { NAWAPO } & \text { National Water Policy } \\ \text { NTU } & \text { Nephelometric Turbidity Units } \\ \text { NWSDS } & \text { National Water Sector Development Strategy } \\ \text { PRISM } & \text { Parameter-elevation Regressions on Independent Slopes Model } \\ \text { RUSLE } & \text { Revised Universal Soil Equation } \\ \text { SORTER } & \text { Soil Terrain Database of East Africa } \\ \text { SWAT } & \text { Soil and Water Assessment Tool } \\ \text { SWRRB } & \text { Simulation for Water Resources in Rural Basins } \\ \text { TANAPA } & \text { Tanzania National Parks Authority } \\ \text { TMA } & \text { Tanzania Metrological Agency } \\ \text { TOPAZ } & \text { Topographic Parameterization Tool } \\ \text { TSS } & \text { Total Suspended Solids } \\ \text { URT } & \text { United Republic of Tanzania } \\ \text { USDA } & \text { United States Department of Agriculture } \\ \text { USLE } & \text { Universal Soil Loss Equation } \\ \text { WEPP } & \text { Water Erosion Prediction Project } \\ \text { WRBWO } & \text { Wami Ruvu Basin Water Office } \\ \text { WUA } & \text { Water Users Associations }\end{array}$




\subsection{INTRODUCTION}

\subsection{Background Information}

Globally, erosion and sediment transport has increased in recent years as a result of land degradation and high amounts of rainfall and intensities. Rainfall and intensities are the most important controlling factors on water erosion and transport of sediment as they affect many geomorphologic processes, including slope stability and channel change (Kundzewicz et al., 2007). On the other hand, settlements on steep slopes, particularly in informal settlements in developing countries can increase vulnerability to water erosion and landslides (Kundzewicz et al., 2007). In Africa, widespread poverty, increased human development activities, and rapid increases in human population size have contributed to land degradation (Sharma et al., 1996). African catchments are affected by soil erosion and sediments that have resulted from loss of vegetation cover. For instance, in East Africa there are more than 100 inhabitants per square kilometer in all areas with an elevation over $2500 \mathrm{~m}$ a.s.1 (Nyssen et al., 2009).

Most African rivers are in tropical mountains characterized by highly productive soils, making them ideal for agricultural activities. Because of the agricultural systems set on abundant altitudinal slopes, these areas receive more attention from local, national and international global policy makers for soil erosion control and watershed management purposes (Nyssen et al., 2009; J. de Vente et al., 2008). In recent years, increased sediment loads have shown why control measures such as soil and water conservation measures are important (Sharma et al., 1996). Alarming cases of increasing sediment loads have been found in the major reservoirs behind Kamburu Dam and Masinga Dam 
in Kenya (Sharma et al., 1996). In other lakes, such as Malawi, Chad, and Victoria, the increased sediment associated with soil erosion and sediment deposition has been linked to a reduction in fish populations (Sharma et al., 1996). However, in the East Africa highlands, soil loss rate is reported to exceed the tolerable recommended limit (10 to 12 tonnes/ha/year) by 50 tonnes/ha/year (Kimaro et al., 2008).

Soil erosion and soil conservation have been major issues in Tanzania as it has been the case of many other tropical countries (Temple, 1972; Kaihura et al, 1999). However, it has been difficult to obtain reliable data on the type, extent and current rates of soil erosion and sedimentation. This is caused by rapid land use changes, unique soils and severe rainfall in tropical areas. The limitation of such information has delayed the current and future interventions for soil and water conservation in critical areas throughout Tanzania. Policy makers have identified soil erosion as a critical problem since the 1920s (Temple, 1972). However, with limited information and resources, education to raise awareness on soil conservation seems like a logical first step (Rapp et al., 1973). In addition, policy makers have been asking for quantification of erosion rates at local, regional and global levels in order to develop environmental and land use management plans which will consider both on-site and off-site impacts of erosion. (J. de Vente et al., 2008). However, because of limited funds, the Tanzanian government decided to concentrate only on land use management rather than implementing extensive projects for soil erosion prevention and conservation (Rapp et al., 1973).

The Wami-Ruvu basin is one of the nine basins in Tanzania that are affected by increased in sediment loads in the country. In order to acquire sustainable water resources in Tanzania, at the basin level, it is recommended by the Tanzanian Government to 
implement the concept of Integrated Water Resources Management (IWRM). This practice ensures that water resources in a basin are sustainably managed for socioeconomic and environmental needs (WRBWO, 2008). Major rivers in eastern Tanzania originate in the forested mountains of the Wami Ruvu basin, and hence most of Morogoro, Pwani and Dar es Salaam depend on the basin for their water supply (Kilahama, 2004). Currently, water quality management in the Wami-Ruvu basin faces challenges related to land use and human activities. Agricultural activities practiced in the basin not only are for food production but also for cash crops (Ngana et al., 2010a; 2010b). Deforestation is another major problem facing the Uluguru, Ukagulu, Nguru and Mgeta forests in the Ruvu sub-basins because of demand for timber, collection of fire wood, and land clearing for agricultural purposes and timber production. However, the forests and woodland cover in the Uluguru Mountains has decreased by $12.7 \%$ and 59.0\% in 1995 and 2000 years, respectively (Yanda and Munishi, 2007).

\subsection{Statement of the Problem}

According to the Tanzania national census report, the population of the basin has been increasing rapidly with an increase of 50\% from 1988 to 2002 . The Morogoro District Council has a population of approximately 304,019 persons with an average population density of 25 people $/ \mathrm{km}^{2}$. The Upper Ruvu catchment on Mt. Uluguru, which includes $60 \%$ of the total population, accommodates $250-300$ people $/ \mathrm{km}^{2}$ (URT, 2011; Mwango, 2000). In the Wami Ruvu basin, the Ruvu River catchment has been affected by agricultural activities near the Uluguru Mountains as a result of population increase. 
Wetlands available in lower Ruvu plains have been affected by increase of sediments (Ngoye and Machiwa, 2004). In addition, observed increase of turbidity from 130 NTU in 1992 to 185 NTU in 2002 in the Ruvu River sub-basin was a result of the increase in agricultural activities (Yanda and Munishi, 2007).

\subsection{Knowledge Gap}

Different studies have been conducted to explain the processes of erosion, identify the major factors influencing the processes, and also develop models suitable to quantify the processes. Most of these models have been "on-site impact oriented" by identifying loss of soil from a field (J. de Vente et al., 2008). The breakdown of soil structure and the decline of organic matter and nutrients, leading to a decline in soil fertility results in reduced food security and vegetation cover. Furthermore, "the off-site effects" of erosion include sedimentation problems in river channels, increased flood risk, and reduced lifetime of reservoirs (J. de Vente et al., 2008).

Within the study area, there have been three different soil erosion studies before implementation of construction of the proposed Kidunda Dam as part of environmental and social impacts assessment. To ensure sustainability of the dam, in 1994 a master plan developed by the Japan International Cooperation Agency (JICA) estimated that sediment

load would range from 300 to $600 \mathrm{tons} / \mathrm{km}^{2} / \mathrm{yr}$, as assessed through the analysis of sediment transport at two stations. In addition to that study, an environmental impact assessment study in 2008 by NORCONSULT evaluated the total solid load at Kidunda to be over 65,000 tons/yr, on the basis of the suspended solid measures taken at two 
stations. However, after the technical team report review, the project was not implemented, and it was suggested that the study be repeated. In 2010, Studio Pietrangel Consulting engineers using the Revised Universal Soil Loss Equation (RUSLE) method estimated soil erosion load at Kidunda Dam to be 448 tons $/ \mathrm{km}^{2} / \mathrm{yr}$. The study did not take into account that eroded elements deposited in the basin but not reached the reservoir. By considering Kidunda Dam sediment studies, which revealed different results of sediment load, there is a need for a detailed field (physical) model to assess and analyze the extent of eroded soil within the catchment that could reach and deposit in the reservoir.

Most available studies and modeling have limitation in the applicability and adaptability to tropical larger watersheds (Ndomba, 2007, 2011). The challenge of slopes and topography is reported to affect sediment loading estimates as compared to total watershed sediment yield at the outlet. Although several soil erosion modeling studies have been adapted from small scale to large tropical watersheds, field measurements, which provide information for validating models, gave unreliable estimates of soil erosion rate and sediment yield (Ndomba, 2010). Application and adaptation of Water Erosion Prediction Project (WEPP) model and methods to the Wami - Ruvu basin to quantify sediment yield and upland and watershed runoff will be an important contribution to the on-going effort to improve the water quality of the river.

\subsection{Justification of the study}

The Ruvu sub-basin in Tanzania is a major source of water in all the coastal regions particularly (Morogoro and Pwani) including the capital city, Dar-es-Salaam. The watershed of this sub-basin has been affected by population increase and land use 
conversion (e.g., agriculture and logging activities; see Bhatia and Buckley, 1998). Consequently, the area has been increasingly susceptible to serious erosion from land cover losses. The catchment slopes steeply and the upper most slopes are covered with rainforest and the lower slopes are under cultivation. One of the most important actions that protect surface waters from sediment loading is the establishment of water quality standards. The basic elements of these standards generally provided for the protection of water resources by designating uses, introducing anti-degradation criteria and other regulatory policies. However, the goals of this approach might not always be attainable, if natural phenomena are not given appropriate consideration.

So far, few attempts have been made to measure the extent of soil erosion and sedimentation in Upper Ruvu Catchment. Equitable Payment for Watershed Services (EPWS) supported by Coca-Cola and CARE is one of the ongoing interventions to address the challenges in the Ruvu River sub-basin as related to water quality. The main objective of EPWS program is to modify unsustainable land use to conserve and improve "watersheds" for reliable supply/flow, water quality, and improvements to quality of life in rural upstream communities. The sustainability of water resource in the basin by different management practices needs to be studied and monitored with reliable baseline information. The present study intends to identify sediment sources under different land uses and sub-watersheds from various soil management practices. Similarly, my study will determine periodic differences in sediment yields to variables related to topography/slope, soil and land use. The expected results intend to be a guiding model to decision makers on soil erosion and water conservation. 


\subsection{Research Objectives and Questions}

My study aims to contribute to the development of a sediment assessment that will provide insights to the nature of the water quality problems related to sediment loading in streams in the Ruvu catchment. My study will estimate the quantity of sediment yield delivered from the upland areas and identify areas that will benefit most from soil conservation practices. It will also assess the impact of the major land use change with time as well as the impact of surface drainage as it relates to sediment yield. In order to achieve these goals, the proposed specific research objectives are to

1. Test the application of WEPP model for hydrologic and erosion modeling in tropical climate watersheds.

2. Identify potential sediment sources areas as related to different land use/cover, topography and soil characteristics.

3. Examine the spatial variations of sediments yields among the sub-watersheds as related to land use changes.

\subsubsection{Research Questions}

My study addresses the following research questions:

i. Where are the erosion hazard and sediment potential areas located in the upper Ruvu catchment?

ii. What factors affect soil erosion and sediments yield spatial distributions?

iii. How does sediment yield and runoff vary as a function of land cover, topography/slope and soil properties in upper Ruvu catchment? 


\subsection{LITREATURE REVIEW}

\subsection{Land degradation}

Land degradation leads to the reduction or loss of biological or economic productivity of land caused by deterioration of physical, chemical and biological or economic properties of soil. According to United Nations Convention to Combat Desertification of 1996, long-term loss of natural vegetation, soil erosion and other land use processes, including human activities and habitation patterns, can cause land degradation. According to Hillel (1991), large-scale degradation of land resources has been reported from many parts of the world in different figures depending on variation of causing factors. The economic impact of land degradation is extremely severe in densely populated areas of South Asia and sub-Saharan Africa that account for $70 \%$ of the total degraded land of the world (Dregne and Chou, 1994). It has been observed that about $75 \%$ of soils in montane areas are the most susceptible because of sheet, rill and gully erosions (Hasan and Alam, 2006). In addition, human alterations of natural ecosystems have caused erosion rates to increase for many areas of the world, resulting in significant land and environmental degradation. For example, in U.S alone there is an average of 1.3 billion tons of soil per year lost from agricultural lands (USDA, 2000).

\subsection{Soil Erosion}

Soil erosion is the physical movement of soil particles from one location to another, mainly because of forces of water or wind. There are three main stages of soil 
erosion including detachment, transport and deposition. The severity of erosion depends upon the quantity of soil detached and the capacity of the wind or water force to transport it (Morgan, 1995). By considering raindrops as falling on the soil surface, both detachment and transport require energy (rainfall velocity, rain drop size, rain drop shape and rainfall intensity). Particles detached and splashed upward can be dropped away ready to be transported by water flow from one location to another location in the watershed/basin. Particles transported by water require a critical velocity to effectively carry sediment; when water velocity slows down, deposition occurs.

There are three main types of water erosion that include interrill, rill and gully erosions. Interrill erosion is caused by detachment and transport of sediment due to shallow overland flow (Elliot et al., 1995). Interrrill erosion is the removal of a thin layer of soil from the surface and is caused by 'overland' flow moving uniformly across the surface. As the interrill erosion continues, water begins to concentrate in small channels. Rill erosion is the detachment and transport of sediment by concentrated channel flow. The concentration of running water causes rill erosion to be more erosive than interrill erosion. Gully erosion occurs when larger quantities of runoff concentrate and create large channels in the landscape (Elliot et al., 1995).

Over decades, soil erosion can have detrimental effects on productivity and soil quality. The majority of soil nutrients and soil organic matter are stored in the topsoil, the soil layer that is most affected by erosion. While temporary solutions, such as increased fertilizer, have offset some of the effects of erosion on productivity, they are not complete substitutes for topsoil (Williams and Tanaka, 1996) and represent the greatest input cost for compensating yield losses caused by erosion (Pimentel et al., 1995). Erosion also 
impacts the environment beyond the farm. Runoff can carry fine sediments, nutrient, and other pollutants to water sources, possibly degrading water quality. Siltation or sedimentation is a leading cause of stream and river impairment in Africa/tropical watersheds as it can cause disturbances in aquatic ecosystems. These include the degradation of fish spawning grounds, the potential reduction of recreational activities, increased cost of domestic water purification and decreased life span of dams and reservoirs. Thus, to maintain long-term productivity and preserve soil and environmental quality, it is important to learn and implement practices that prevent and minimize erosion, rather than manage the effects of erosion after it has occurred (Pimentel et al., 1995).

\subsection{Factors Influencing Water Soil erosion}

Land use changes and related human activities can influence soil erosion rates (Figure 2-1). For example, the changes from natural vegetation can increase sediment transport by streams and rivers within the watershed. Moreover, clearance of natural vegetation can cause an increase in sediment yield (Walling, 1999). Agricultural activities have been increasing in the Wami-Ruvu basin not only for food production but

also for cash crops. Cash crops include large scale (sugarcane, sisal and cotton) and food crops (maize, rice, potatoes and beans). Also, the area is a major producer of fruits (oranges, bananas, water melon, and passions, pine apples) (Ngana et al., 2010).

Land steepness and slope length are critical factors in determining soil erosion. Flat fields with 1-2 percent slopes may not be very prone to erosion, but fields with 
slopes of 10-15 percent slopes will likely be very prone to erosion. However, when slope of the land studied together with length of the field, it is expected that long fields with a constant slope of 2 percent may erode severely. Erosion water builds momentum as it moves down the slope and the higher water velocity will mean the more energy it has for transporting soil. Rivers at upper Ruvu catchment starting at high elevation in Uluguru Mountain and the steep slopes influence erosion and sediment loading at watersheds outlet.

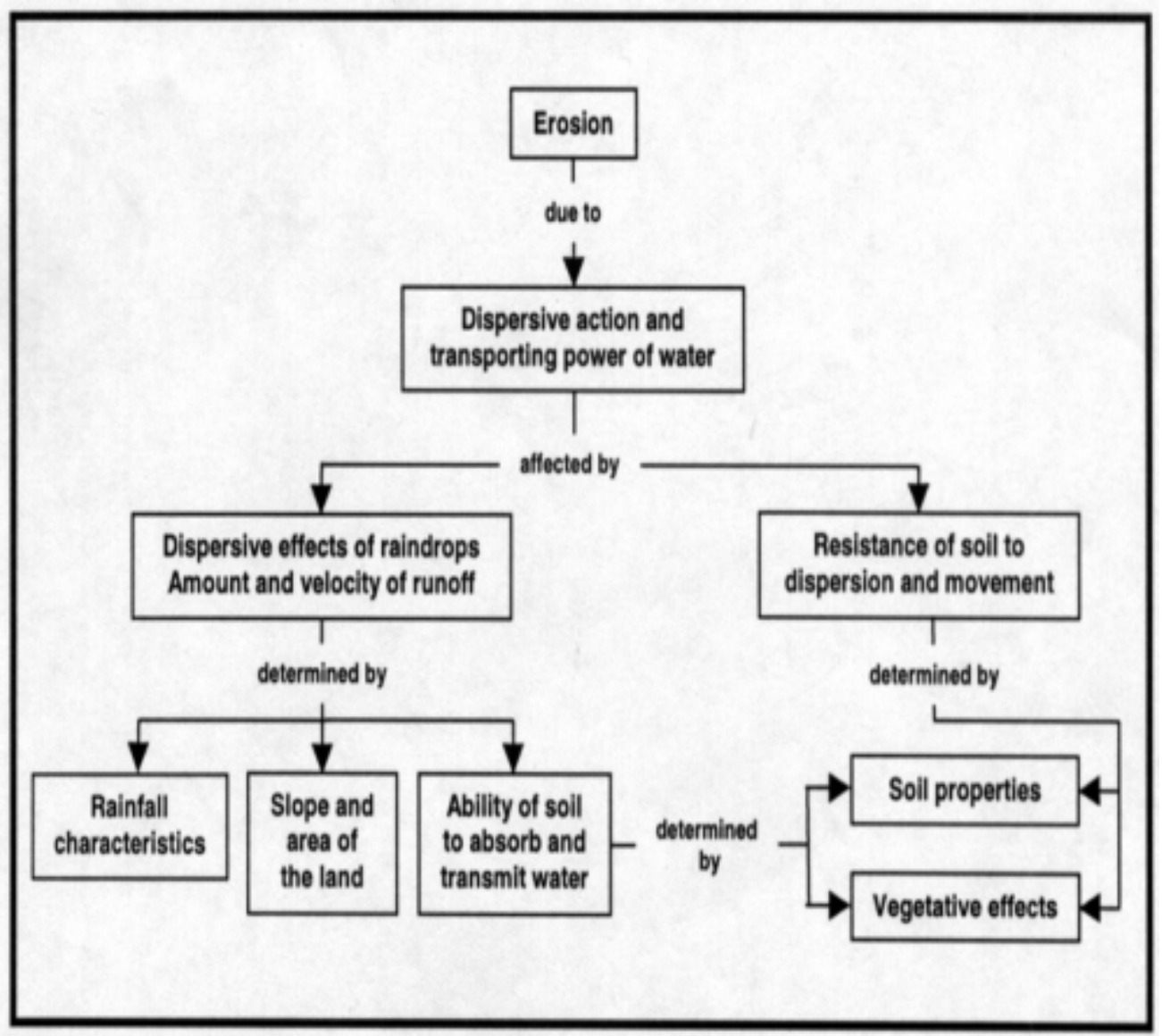

Figure 2.1. Factors affecting soil erosion by water (Source: Branson et al., 1981) 


\subsection{Description of Sediments}

The origin of sediment is from the weathering of rocks. After weathering, the sediment particle is being carried by stream to be deposited in the downstream drainage areas. The amount of sediment load carried depends on the size of material, discharge, slope and channel, and catchment characteristics. In water erosion, the agent of erosion is mainly water but in arid areas, wind erosion is a predominant factor which is not part of this study. The sediment particle is being further defined by their properties (Pepper et al., 1999).

\subsection{Sediment Transport and Deposit}

Properties of sediment deposits are defined in terms of the deposit's porosity, specific weight, and consolidation rate. Although there are different factors contributing to sediment source, but also their deposits depend on the watershed characteristics including land use, catchment morphology and drainage network density (Walling, 1994). There are four main agents of sediment transport. These are water, gravity, wind, and ice. These agents can cause different types of flow depending on the velocity of their movement over sediments (Garde and Raju, 2000). In water and other fluids, there are two main types of flow including laminar and turbulent. According to hydrologic process, turbulence entrains particles and keeps some of them in suspension. In natural rivers, sediments can be categorized into two types;-suspended load and bed load (Adeogun et al., 2011). Bed load is that transported close to bed where particles moving by rolling, sliding or jumping. In addition, due to complicated mode of transport, it has 
been observed fluctuating measurement results in both vertical and longitudinal measurements. Suspended load is one that swept along the local flow of velocity, supported by turbulence (Adeogun et al., 2011). All these are important in hydrologic practices of river restoration, ecosystem protection, navigation, watershed studies and reservoir conservation. Sediment deposit affects river basin hydrological characteristics by changing channel morphology and physical surroundings (Prosser et al, 2001; Young et al, 2001).

\subsection{Sediment Load and Sediment Yield}

Sediment yield is generally defined as a catchment total sediment outflow and that can be determined at a specific point of reference for a given length of time. The sediment delivered to and transported by a stream is its sediment load. This can be classified into three types, depending on sediment size and the competence of the river. Scientists have been working through different strategies for updating global sediment yields in rivers and establishing primary controls using river load data since 1960s. Sediment yield is generally expressed in two ways: either as a volume or as a weight (i.e., as acre-feet (one-foot depth of material over one acre) or as tons). However, In order to adjust for the very different sizes of drainage basins, the yield frequently is expressed as a volume or weight per unit area of drainage basin (e.g., as acre-feet per square mile or as tons per square mile or per square kilometer). Further, sediment yield is usually measured during a period of years, and the results are thus expressed as an annual average. The reviewing of information is an ongoing process because of limited information on the suspended sediment loads of World Rivers. Many regions of the world remain 
unrepresented or poorly represented by using data from larger rivers with exclusion of other rivers from Africa, Asia and South America (Walling, 1994). In addition, different methods of sampling, assessment and calculating sediment load has resulted in significantly different estimates of sediment yield. There are three types of sediment constitute the total sediment load of the stream and the sediment yield of the drainage basin. These are coarsest sediment (boulders, cobbles and sand), finer particles (silts and clays) and dissolved load, which is composed chemical compounds in solution form taken by the flowing water. However, much information on total sediment flux has been available within the basins' outlet to the ocean with little known about the variation of specific sediment yield within catchments. Although total sediment load/flux represents small percent of the total land area eroded and converted to sediments but still is a good source of information for management of soil erosion and sedimentation within the basin (Walling, 1994).

\subsection{Sediment Modeling}

There are different methods that can be applied directly at the field scale to measure soil erosion and sediment yield including the use of erosion pins, runoff plots, shrub-mounds and pedestals. These methods can determine soil erosion or sedimentation at the specific point in landscape such as quantity in reservoirs and sediment concentration in rivers. Because of lack of information on the spatial distribution of sediment sources in watersheds with complex landscapes, researchers generally prefer using a combination of in-situ (direct, local, on the ground) data and modeling to measure 
soil loss. This has been accommodated by a comprehensive description of some of the most popular models of watershed hydrology and soil erosion in the world that can be found in various studies and literatures.

Soil loss modeling can be broken down into three categories; Empirical models (USLE and RUSLE), Conceptual models (AGNPS, SWAT and AGWA) and Physical models (CREAMS, WEPP and ANSWERS). All these models vary in their applicability scale and simulation outputs as shown in the table below. 
Table 2.1. Types of Sediment models and their input requirements

\begin{tabular}{|c|c|c|c|c|c|c|}
\hline Type & Model & $\begin{array}{l}\text { Spatial } \\
\text { scale }\end{array}$ & $\begin{array}{l}\text { Temporal } \\
\text { scale }\end{array}$ & $\begin{array}{l}\text { Data } \\
\text { Demand }\end{array}$ & Output & Source \\
\hline \multirow[t]{2}{*}{ Empirical } & $\begin{array}{l}\text { USLE (Universal } \\
\text { Soil Loss } \\
\text { Equation) }\end{array}$ & Hillslope & Annual & Low & Erosion & $\begin{array}{l}\text { (Flanagan et } \\
\text { al., 2001), }\end{array}$ \\
\hline & $\begin{array}{l}\text { RUSLE (Revised } \\
\text { Universal Soil } \\
\text { Loss Equation) }\end{array}$ & Hillslope & Annual & Low & Erosion & $\begin{array}{l}\text { (Renard et al, } \\
\text { 1997) }\end{array}$ \\
\hline \multirow[t]{3}{*}{ Conceptual } & $\begin{array}{l}\text { AGNPS } \\
\text { (Agricultural } \\
\text { Non-Point } \\
\text { Source Pollution } \\
\text { Model) }\end{array}$ & $\begin{array}{l}\text { Small } \\
\text { catchments }\end{array}$ & $\begin{array}{l}\text { Event/ } \\
\text { continuous }\end{array}$ & High & $\begin{array}{l}\text { Runoff, } \\
\text { peak rate, } \\
\text { erosion, } \\
\text { sediment } \\
\text { yield }\end{array}$ & $\begin{array}{l}\text { (Young et al., } \\
1989 \text { ) }\end{array}$ \\
\hline & $\begin{array}{l}\text { SWAT (Soil and } \\
\text { Water } \\
\text { Assessment } \\
\text { Tool) }\end{array}$ & $\begin{array}{l}\text { catchment/ } \\
\text { basin }\end{array}$ & Continuous & High & $\begin{array}{l}\text { Runoff, } \\
\text { peak rate, } \\
\text { erosion, } \\
\text { sediment } \\
\text { yield }\end{array}$ & $\begin{array}{l}\text { Arnold et al., } \\
1990 \text { \&1998) }\end{array}$ \\
\hline & $\begin{array}{l}\text { AGWA } \\
\text { (Automated } \\
\text { Geospatial } \\
\text { Watershed } \\
\text { Assessment } \\
\text { Tool) }\end{array}$ & $\begin{array}{l}\text { catchment } \\
\text { /basin }\end{array}$ & Continuous & High & $\begin{array}{l}\text { Runoff, } \\
\text { peak rate, } \\
\text { erosion, } \\
\text { sediment } \\
\text { yield }\end{array}$ & $\begin{array}{l}\text { (Miller et al, } \\
1996,2002 \text { ) }\end{array}$ \\
\hline \multirow[t]{3}{*}{ Physical } & $\begin{array}{l}\text { ANSWERS } \\
\text { (Areal Nonpoint } \\
\text { Source } \\
\text { Watershed } \\
\text { Environment } \\
\text { Response } \\
\text { Simulation) }\end{array}$ & $\begin{array}{l}\text { Small } \\
\text { catchments }\end{array}$ & $\begin{array}{l}\text { Event/ } \\
\text { continuous }\end{array}$ & High & $\begin{array}{l}\text { Runoff, } \\
\text { peak rate, } \\
\text { erosion, } \\
\text { sediment } \\
\text { yield }\end{array}$ & $\begin{array}{l}\text { (Beasley et al, } \\
\text { 1980), (De } \\
\text { Roo et al, } \\
1989)\end{array}$ \\
\hline & $\begin{array}{l}\text { CREAMS } \\
\text { (Chemicals, } \\
\text { Runoff and } \\
\text { Erosion from } \\
\text { Agricultural } \\
\text { Management } \\
\text { Systems) }\end{array}$ & Plot/field & Continuous & High & $\begin{array}{l}\text { Erosion, } \\
\text { deposition }\end{array}$ & $\begin{array}{l}\text { (Knisel, 1980), } \\
\text { (Nyhan and } \\
\text { Lane,1982), } \\
\text { (Lane, 1984) }\end{array}$ \\
\hline & $\begin{array}{l}\text { WEPP (Water } \\
\text { Erosion } \\
\text { Prediction } \\
\text { Project) }\end{array}$ & $\begin{array}{l}\text { Hillslope/ } \\
\text { catchment }\end{array}$ & Continuous & High & $\begin{array}{l}\text { Runoff, } \\
\text { sediment } \\
\text { yield, soil } \\
\text { loss }\end{array}$ & $\begin{array}{l}\text { (Nearing et al, } \\
\text { 1989), } \\
\text { (Wischmeier, } \\
\text { 1978), (Foster } \\
\text { and Lane, } \\
\text { 1987) (Elliot et } \\
\text { al, 1995), } \\
\text { (Flanagan et } \\
\text { al., 2007) }\end{array}$ \\
\hline
\end{tabular}




\subsection{Universal Soil Loss Equation (USLE/RUSLE)}

Universal Soil Loss Equation (USLE) is the first equation for predicting soil losses from water erosion developed in the mid-western United States. The comprehensive soil loss prediction equation was developed by scientists at USDANatural Resources Conservation Services to predict the long-term average soil losses from specific field areas in specific cropping and management systems. The model has been the most widely accepted and utilized soil loss equation. The model takes into account the major factors that influence soil erosion. These include rainfall patterns, soil types, slope steepness and management and conservation practices (Renard et al, 1997).

\subsection{Water Erosion Prediction Project (WEPP)}

The Water Erosion Prediction Project is aimed at developing process-based prediction technology to replace the USLE. The WEPP model operates on a continuous daily basis by using mainly physically based equations. It describes hydrologic and sediment generation and transport processes at the hillslope and in-stream scales (Baigorria et al., 2007). Research must give more consideration to how erodibility changes with time in field situations, and particularly on processes that describe overland flow and spatial and temporal scale variation (Elliot et al., 1991). The basic WEPP hillslope model components are weather generation (climate), surface hydrology, hydraulics of overland flow, hillslope erosion, water balance, plant growth, residue management and decomposition, soil disturbance by tillage, and irrigation (Foster and Lane, 1987). With applicability limitations and availability of data to this study, main 
input components are weather generation, surface hydrology, hydraulics of overland flow, hillslope erosion, residue management and decomposition and soil disturbances. A unique aspect of the WEPP technology is the separation of the erosion processes into rill detachment (as a function of excess flow shear stress) and interrill detachment. Additionally, the model simulates sediment transport and deposition, and off-site sediment particle size distribution. These items allow better assessment of soil erosion at a site, and subsequent sediment transport to channels and impoundments in watersheds (Foster and Lane, 1987).

WEPP has been tested and applied in different geographic locations across the world. In Peru (Baigorria, 2007), the model validated using three different sized runoff plots, at four locations under natural rainfall events. According to Baigorria (2007), all climatic characteristics, soil physical parameters, topographical and management characteristics were determined in the field and laboratory. The measured runoff and erosion from agricultural fields were low compared to predicted levels. Poor relationship between runoff and sediment yield as well as rainfall and runoff was observed, and this poor relationship was observed because of the dynamic change in soil properties during rainfall event due to sealing.

In Africa, with little modifications, WEPP has increased interest for researchers in particular watersheds located in high elevation areas. WEPP has been tested in Anjani watershed, Ethiopian highlands (Setegn, 2009). The emphasis was on the new standalone program to create climate input file for WEPP using standard weather datasets called Breakpoint Climate Data Generator (BPCDG). However, the final results over predicted runoff and under estimated soil loss. In additional to that, validation of the model was 
done in Kenya at Amala and Nyangore upstream watersheds of Mara River basin (Defersha, 2010). Simulation over estimated runoff compared to observed results while the sediment yield and erosion were slightly similar in different land use areas as expected (Defersha, 2010). In North Africa, the analysis of model performance through sediment yield and runoff predication conducted on Mediterranean cultivated Kamach catchment, Tunisia (Raclot and Albergel, 2006).

\subsubsection{Surface hydrology}

Hydrology within the watershed reflects on the effects of water balance, channel hydrology and soil effects. WEPP mathematical calculations of channel hydrology and water balance is the result of infiltration, evapotranspiration, soil water percolation, canopy rainfall interception and surface depressional storage. The model uses the GreenAmpt Mein-Larson approach to simulate the temporal changes in infiltration rate during the rainstorm (Ascough et al., 1997). Runoff which is rainfall excess occurs when rainfall rate exceeds infiltration rate. This is assumed to start after the depression storage is filled. The differential form of mathematical equation for soil matrix of infinite depth is:

$$
i=k_{e}+\left(1+\frac{\left(\emptyset-\theta_{0}\right) \varphi_{c}}{I}\right)
$$

Where $\mathrm{i} \quad$ Actual infiltration rate $\left(\mathrm{m} \mathrm{s}^{-1}\right)$

$\mathrm{K}_{\mathrm{e}} \quad$ Effective hydraulic conductivity of the wetted zone $\left(\mathrm{m} \mathrm{s}^{-1}\right)$

$\theta_{0} \quad$ Initial saturation $\left(\mathrm{m}^{3} \mathrm{~m}^{-3}\right)$

$\emptyset \quad$ Effective porosity $\left(\mathrm{m}^{3} \mathrm{~m}^{-3}\right)$ 
$\varphi_{c} \quad$ Effective capillary tension or wetting front suction potential (m)

I Cumulative infiltration (m)

Water balance is based on a component of the Simulator for Water Resources in Rural Basins (SWRRB) model with some modifications for improving estimation of percolation and soil evaporation parameters (Ascough et al., 1997). The distribution of water through soil layers is based on evapotranspiration percolation models and storage routing techniques. If the potential surface storage depression is completely satisfied, the positive difference between the net rainfall intensity at the ground surface and the infiltration rate becomes the input to the overland flow calculation (Defersha, 2010). The basic equations which describe the movement of water are based on the laws of mass and momentum conservation:

$$
\frac{\partial A}{\partial t}+\frac{\partial Q}{\partial x}=r(t)-i(t)=q(x, t)
$$

And

$$
Q=\alpha P R^{m-1}
$$

With

$$
\alpha=C \sqrt{s}
$$

Where
A Cross-sectional area $\left(\mathrm{m}^{2}\right)$
t Time (s)
Q Discharge $\left(\mathrm{m}^{3} / \mathrm{s}\right)$
$\mathrm{x} \quad$ Down slope distance (m) 


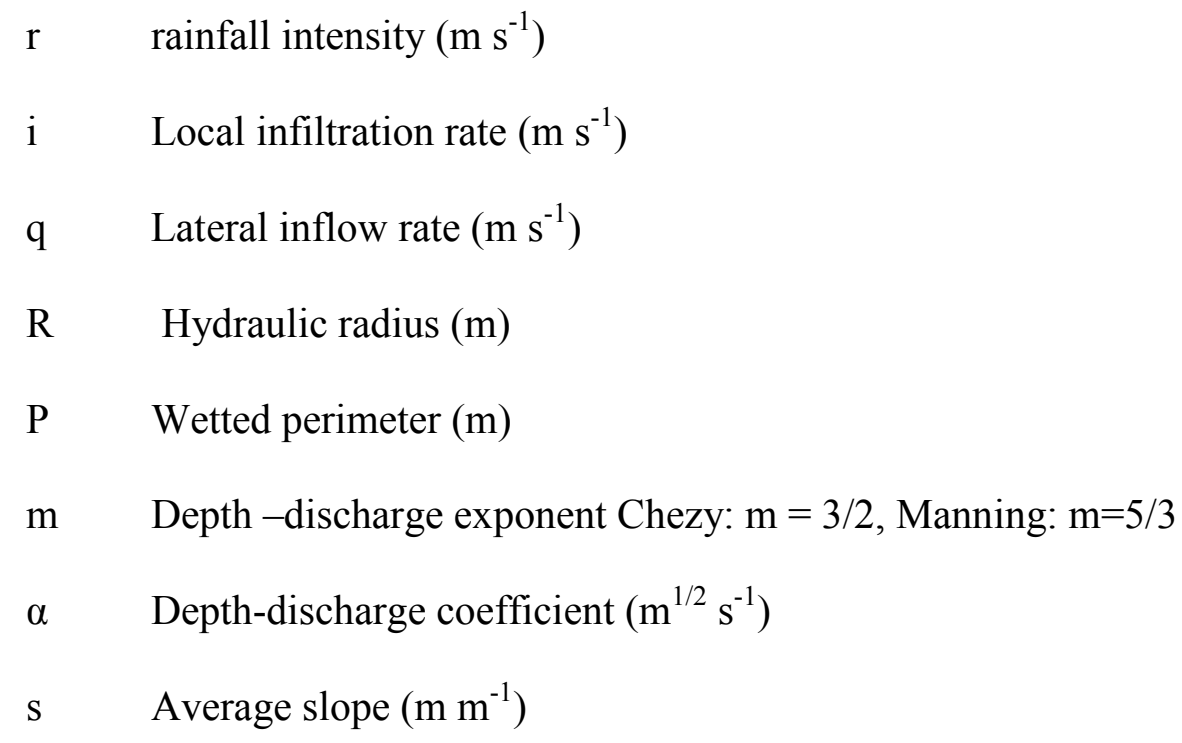

In WEPP, the overland flow is conceptualized as plane runoff which means that A is substituted by the average flow depth $\mathrm{h}$ (expressed in $\mathrm{m}$ ). Equations (2.5) and (2.6) are solved analytically by the methods of characteristics which require the rewriting of these equations as differential equations on characteristics curve on the $\mathrm{x}$-t plane (Flanagan and Nearing, 1995):

$$
\frac{d h}{d t}=v(t)
$$

And

$$
\frac{d x}{d t}=\alpha m h(t)^{m-1}
$$

$\begin{array}{lll}\text { Where } & \mathrm{h} & \text { Flow depth }(\mathrm{m}) \\ \mathrm{v} & \text { Runoff or rainfall excess }\left(\mathrm{m} \mathrm{s}^{-1}\right)\end{array}$


These equations are solved together with the infiltration calculations by using a RunggeKutta iteration scheme with as spatial resolution of one hundredth of the total hill slope length and a time step of one minute.

\subsubsection{Hillslope Erosion}

The WEPP model divides erosion into two types: rill and interrill erosion. The movement of the sediment along the hillslope is described on the basis of the steady-state sediment continuity equation which is applied flow conditions (Elliot et al., 1995; Flanagan et al., 2007; Nearing et al., 1989):

$$
\frac{d G}{d x}=D_{i}+D_{r}
$$

Where
G Sediment load $\left(\mathrm{kg} \mathrm{sec}^{-1} \mathrm{~m}^{-1}\right)$
$\mathrm{x} \quad$ Distance down slope $(\mathrm{m})$
$D_{\mathrm{r}} \quad$ Rill erosion rate $\left(\mathrm{kg} \mathrm{sec}^{-1} \mathrm{~m}^{-1}\right)$
$\mathrm{D}_{\mathrm{i}} \quad$ Interrill erosion rate $\left(\mathrm{kg} \mathrm{sec}^{-1} \mathrm{~m}^{-1}\right)$ 
The interrill erosion is estimated from the equation

$$
D_{i}=K_{i} I^{2} S_{f} f(C)
$$

Where

$\mathrm{D}_{\mathrm{i}} \quad$ Detachment rate $\left(\mathrm{kg} \mathrm{sec} \mathrm{m}^{-1}\right)$

$\mathrm{K}_{\mathrm{i}} \quad$ Interrill soil erodibility parameter $\left(\mathrm{kg} \mathrm{sec}^{-1} \mathrm{~m}^{-4}\right)$

I Effective rainfall intensity $\left(\mathrm{m} \mathrm{sec}^{-1}\right)$

$\mathrm{S}_{\mathrm{f}} \quad$ Slope factor $\left(\mathrm{m} \mathrm{sec}^{-1}\right)$

f(c) Function of canopy and residue

The erosion rate in rill erosion is a function of hydraulic shear and amount of sediment already in the flow (Elliot et al., 1995; Nearing et al., 1989). Rill is estimated in WEPP model by:

$$
D_{r}=K_{r}\left(t-t_{c}\right)\left(1-\frac{G}{T_{c}}\right)
$$

Where

$\mathrm{D}_{\mathrm{r}} \quad$ Rill erosion rate $\left(\mathrm{kg} \mathrm{sec}^{-1} \mathrm{~m}^{-2}\right)$

$\mathrm{K}_{\mathrm{r}} \quad$ Rill soil erodibility parameter $\left(\mathrm{sec}^{-1}\right)$

$\mathrm{t} \quad$ Hydraulic shear of water flowing in the rill $(\mathrm{Pa})$

$t_{c} \quad$ Critical shear below which no erosion occurs $(\mathrm{Pa})$

G Sediment transport rate $\left(\left(\mathrm{kg} \mathrm{sec}^{-1} \mathrm{~m}^{-1}\right)\right.$

$\mathrm{T}_{\mathrm{c}} \quad$ Rill sediment transport capacity $\left(\mathrm{kg} \mathrm{sec} \mathrm{m}^{-1}\right)$ 


\subsection{DESCRIPTION OF THE STUDY AREA}

\subsection{Location}

Wami- Ruvu Basin covers approximately $66,820 \mathrm{~km}^{2}$ with three sub- catchments which are the Wami catchment $43,946 \mathrm{~km}^{2}$, Ruvu catchment $18,078 \mathrm{~km}^{2}$, and Coastal Rivers $4,796 \mathrm{~km}^{2}$. Ruvu River sub-basin is located between latitudes $6^{\circ} 05^{\prime} \mathrm{S}$ and $7^{\circ} 45^{\prime} \mathrm{S}$ and longitudes $37^{\circ} 15^{\prime} \mathrm{E}$ and $39^{\circ} 00^{\prime} \mathrm{E}$ (Figure 3.1). The main rivers in this basin are Mvuha, Mfizigo, Ruvu and Mgeta whose headwaters are in the Uluguru and Mgeta mountains 2634 meters above sea (WRBO, 2010 Progress report). For detailed study, the sub-basin was delineated further to get four sub-watersheds which are Mgeta, Kibungo, Ngerengere and Ruvu. To fulfill the objectives, this study focused on Kibungo subwatershed. The selections for this watershed in the study considered rivers which are not regulated (naturally or artificially), those regulated and the importance of geographical region. 


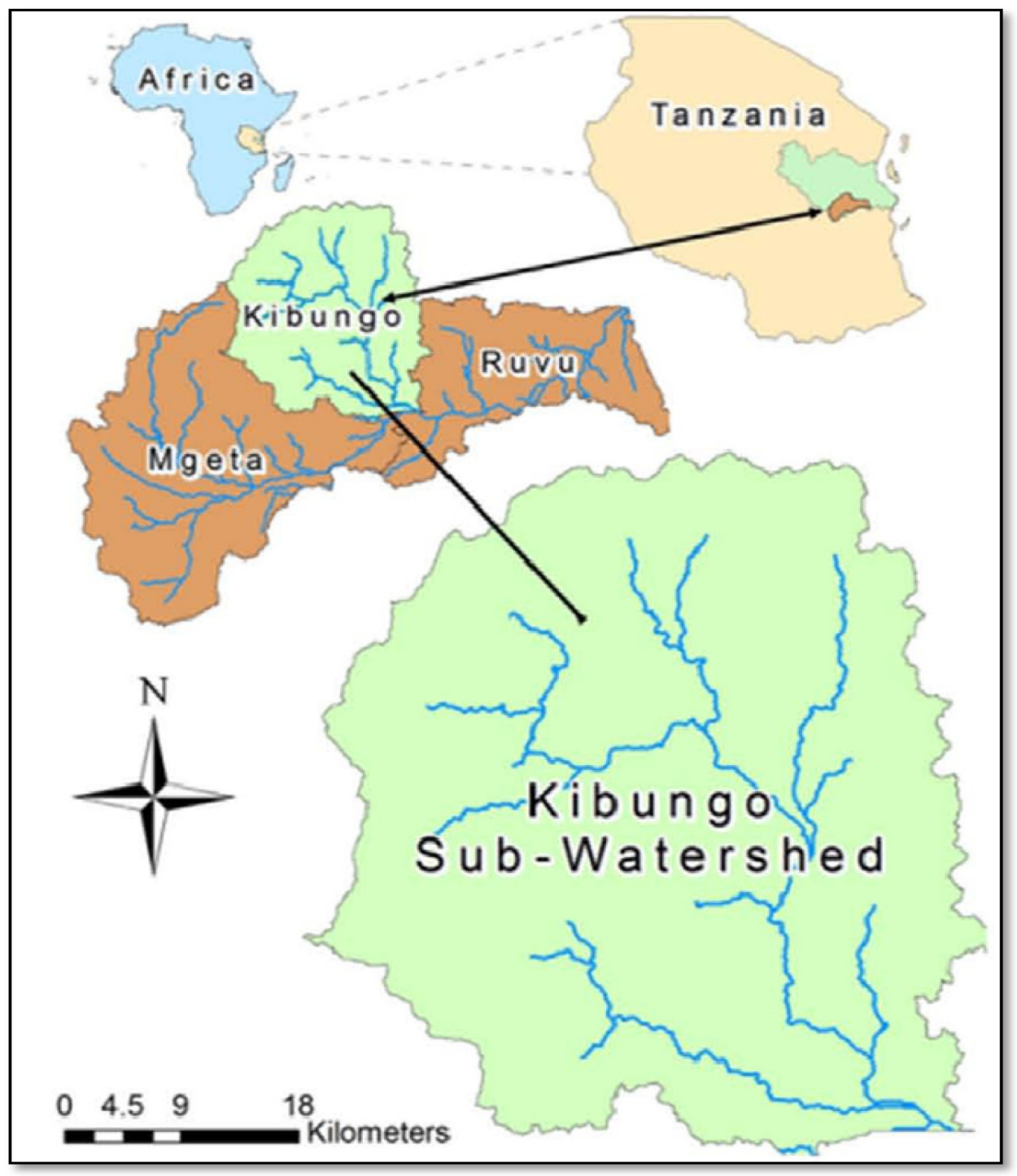

Figure 3.1. Location of the study area

\subsection{Climate}

Two main climate regimes can be identified during the year in this area: the heavy long rainy season or Masika (December to May), and the dry season or Kiangazi (June to November). There is a spatial variability of rainfall within the Wami-Ruvu River basin. In the upper Ruvu River catchment, there is temporal and spatial variability in 
rainfall with upstream areas receiving more rain than downstream locations as shown in Table 3.1 and Figure 3.2. For this study, a total of ten (10) available meteorological/weather stations were selected; Matombo Primary School, Hobwe, Morning side, Mikula, Kisaki, Ng'ese Utari, Duthumi Singisa, Mtamba and Ruvu at Kibungo. Based on information from these gauges, the mean annual rainfall varies from 900 to $1300 \mathrm{~mm}$ and daily temperature ranges between $22^{\circ} \mathrm{C}$ and $33^{\circ} \mathrm{C}$.

Table 3.1. Lists of weather stations selected with available data

\begin{tabular}{|c|c|c|c|c|c|c|c|}
\hline \multirow[t]{2}{*}{ Code } & \multicolumn{2}{|c|}{ Coordinate } & \multirow{2}{*}{$\begin{array}{l}\text { Elevation } \\
\text { (m a.s.l) }\end{array}$} & \multirow{2}{*}{$\begin{array}{l}\text { Name of } \\
\text { Station }\end{array}$} & \multirow{2}{*}{$\begin{array}{l}\text { MWI } \\
\text { (monthly) }\end{array}$} & \multirow{2}{*}{$\begin{array}{l}\text { TMA } \\
\text { (Daily) }\end{array}$} & \multirow{2}{*}{$\begin{array}{l}\text { Morogoro } \\
\text { (Daily) }\end{array}$} \\
\hline & Lat & Lon & & & & & \\
\hline 9637046 & $6^{\circ} 54^{\prime}$ & $37^{\circ} 40^{\prime}$ & 1450 & $\begin{array}{l}\text { Morningside } \\
\text { Farm }\end{array}$ & $1951-2005$ & - & $1966-2010$ \\
\hline 9637047 & $6^{\circ} 59^{\prime}$ & $37^{\circ} 34^{\prime}$ & 740 & Hobwe & 1954-2005 & $1973-2009$ & $1971-2010$ \\
\hline 9737005 & $7^{\circ} 15^{\prime}$ & $37^{\circ} 43^{\prime}$ & 460 & $\begin{array}{l}\text { Singisa } \\
\text { Catholic } \\
\text { Mission }\end{array}$ & $1950-1995$ & $\begin{array}{l}1973-2000 \\
\& 2005- \\
2007\end{array}$ & - \\
\hline 9737006 & $7^{\circ} 05^{\prime}$ & $37^{\circ} 46^{\prime}$ & 390 & $\begin{array}{l}\text { Matombo } \\
\text { Mission }\end{array}$ & $1950-2005$ & $1973-2009$ & $1971-2010$ \\
\hline 9737026 & $7^{\circ} 01^{\prime}$ & $37^{\circ} 48^{\prime}$ & 270 & $\begin{array}{l}\text { Kibungo } \\
\text { Maji }\end{array}$ & $1955-1983$ & $1973-2009$ & $1971-2010$ \\
\hline 9737008 & $7^{\circ} 28^{\prime}$ & $37^{\circ} 36^{\prime}$ & 180 & Kisaki & $1950-1980$ & $1938-1980$ & - \\
\hline 9738009 & $7^{\circ} 01^{\prime}$ & $38^{\circ} 19^{\prime}$ & 90 & $\begin{array}{l}\mathrm{Ng}^{\prime} \text { Hess } \\
\text { Utari Bridge }\end{array}$ & $1956-2000$ & - & $2005-2008$ \\
\hline 9738016 & $7^{\circ} 15^{\prime}$ & $38^{\circ} 15^{\prime}$ & 80 & $\begin{array}{l}\text { Mikula } \\
\text { (Magogoni) }\end{array}$ & $1980-2000$ & $\begin{array}{l}1976-1998 \\
\& 2001\end{array}$ & $2005-2008$ \\
\hline 9737000 & $7^{\circ} 23^{\prime}$ & $37^{\circ} 48^{\prime}$ & 90 & Duthumi & $193-1986$ & $1949-1983$ & - \\
\hline 9737017 & $7^{\circ} 04^{\prime}$ & $37^{\circ} 46^{\prime}$ & 920 & Mtamba & 1974-1987 & $\begin{array}{l}1982- \\
1998,2006\end{array}$ & - \\
\hline
\end{tabular}

MWI = Ministry of Water Irrigation; TMA = Tanzania Meteorological Agency 
Normally, evaporation is higher than rainfall in the catchment. According to Annual Penman potential evapotranspiration is $2000 \mathrm{~mm} / \mathrm{year}$ in the basin and between 1600 and $1800 \mathrm{~mm} /$ year in the Uluguru Mountains (Gomani et al, 2010).
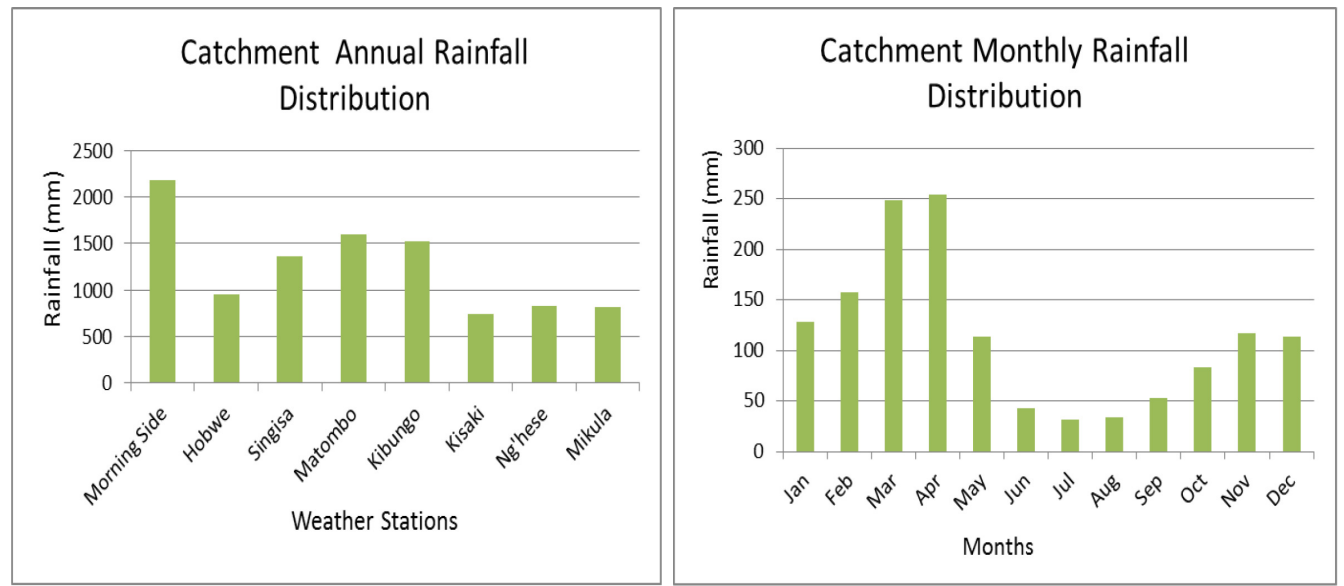

Figure 3.2. Rainfall variation in the upper Ruvu catchment as recorded in eight weather stations (1950-2005) average

The graph below indicates the mean monthly rainfall variation as recorded from Tanzania Meteorological Agency (TMA) and Morogoro weather station installed at Wami Ruvu Basin Office (WRB). Selection of weather stations considered variation in rainfall and elevations in the upstream and downstream side of the catchment (Figure $3.3)$. 


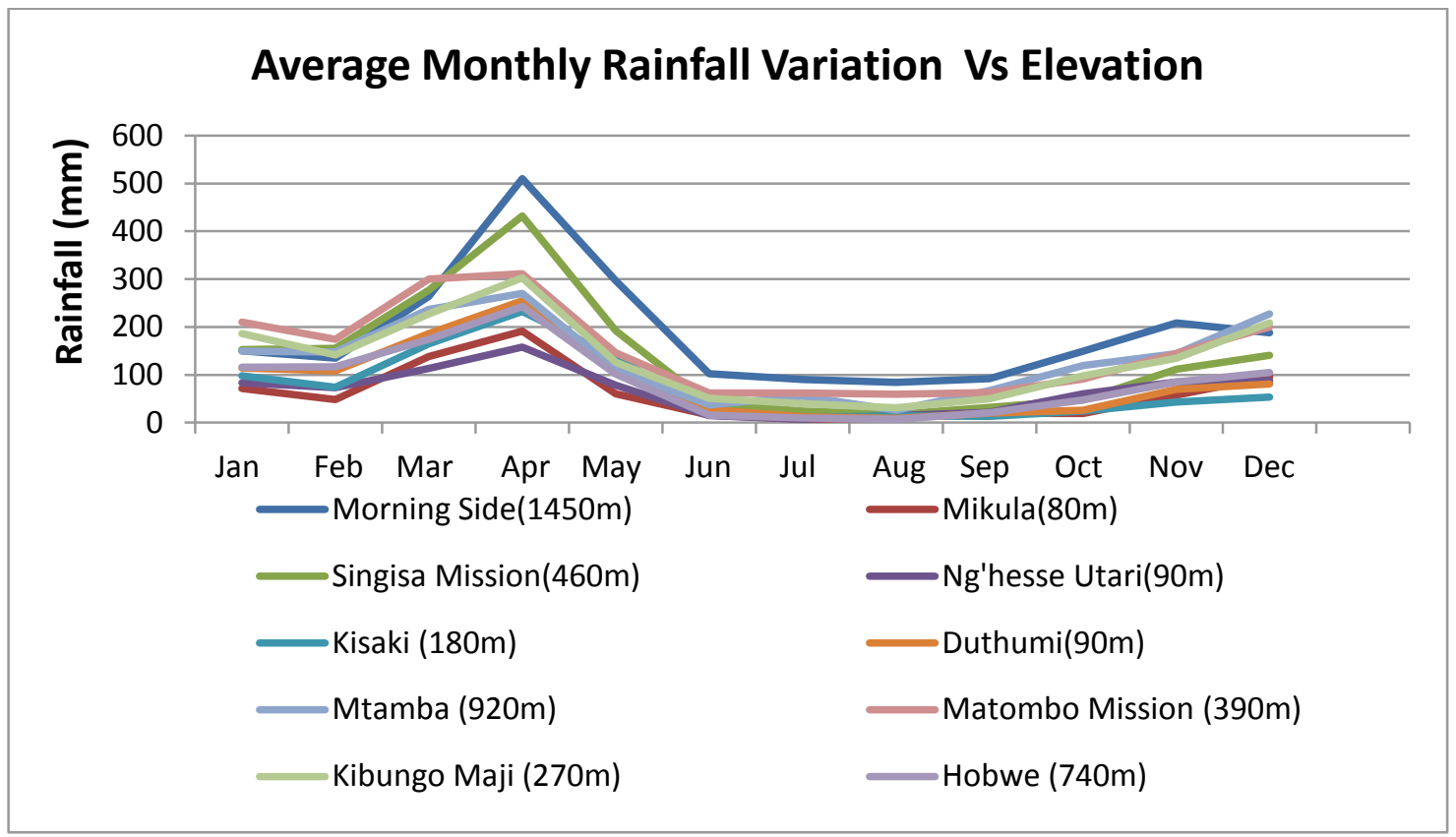

Figure 3.3. Rainfall variation with elevation: Upstream and downstream of the upper Ruvu catchment

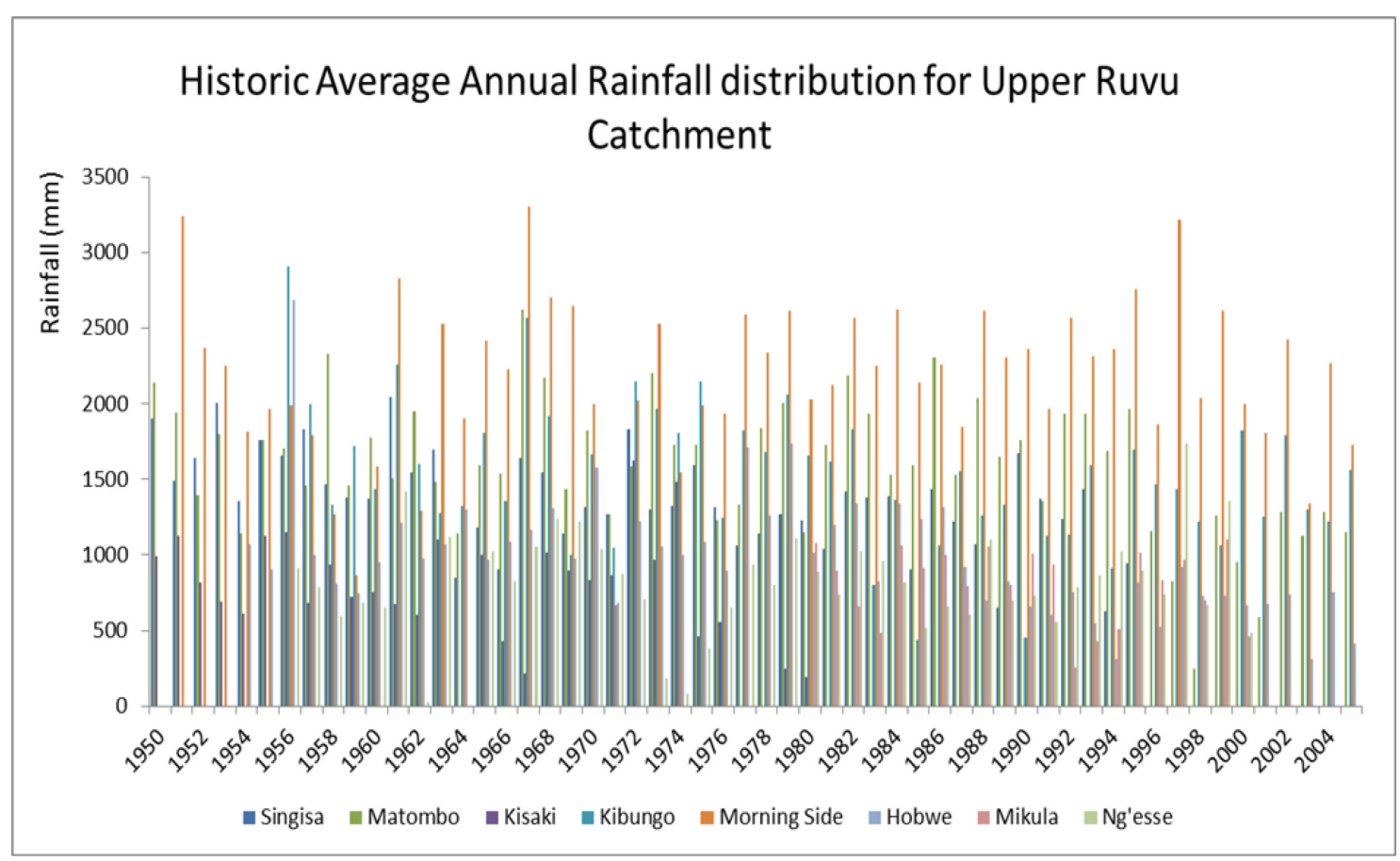

Figure 3.4. 55-years average annual rainfall variation within selected weather stations 


\subsection{Hydrology}

Ruvu is the main river fed by its tributaries; Mgeta, Mfizigo, Mvuha and other small streams. The regime of the Ruvu River reflects the trend of the wet and dry seasons (Figure 3.4). According to basin office and Ministry of Water report, the river flows at the Kidunda and Mikula stations decreases from about $60 \mathrm{~m}^{3} / \mathrm{s}$ in May to around $25 \mathrm{~m}^{3} / \mathrm{s}$ in October or September. After this month, it rises slowly reaching $70 \mathrm{~m}^{3} / \mathrm{s}$ in December. In January and February, the flows arrive at $60 \mathrm{~m}^{3} / \mathrm{s}$ and $50 \mathrm{~m}^{3} / \mathrm{s}$, respectively. The highest monthly average flow is reached in April (around $160 \mathrm{~m}^{3} / \mathrm{s}$ ). The lowest value of about $5 \mathrm{~m}^{3} / \mathrm{s}$ have been reached in October. The mean annual flow is approximately $66 \mathrm{~m}^{3} / \mathrm{s}$ (SP Studio Pietrangel Consulting Engineers, 2010).
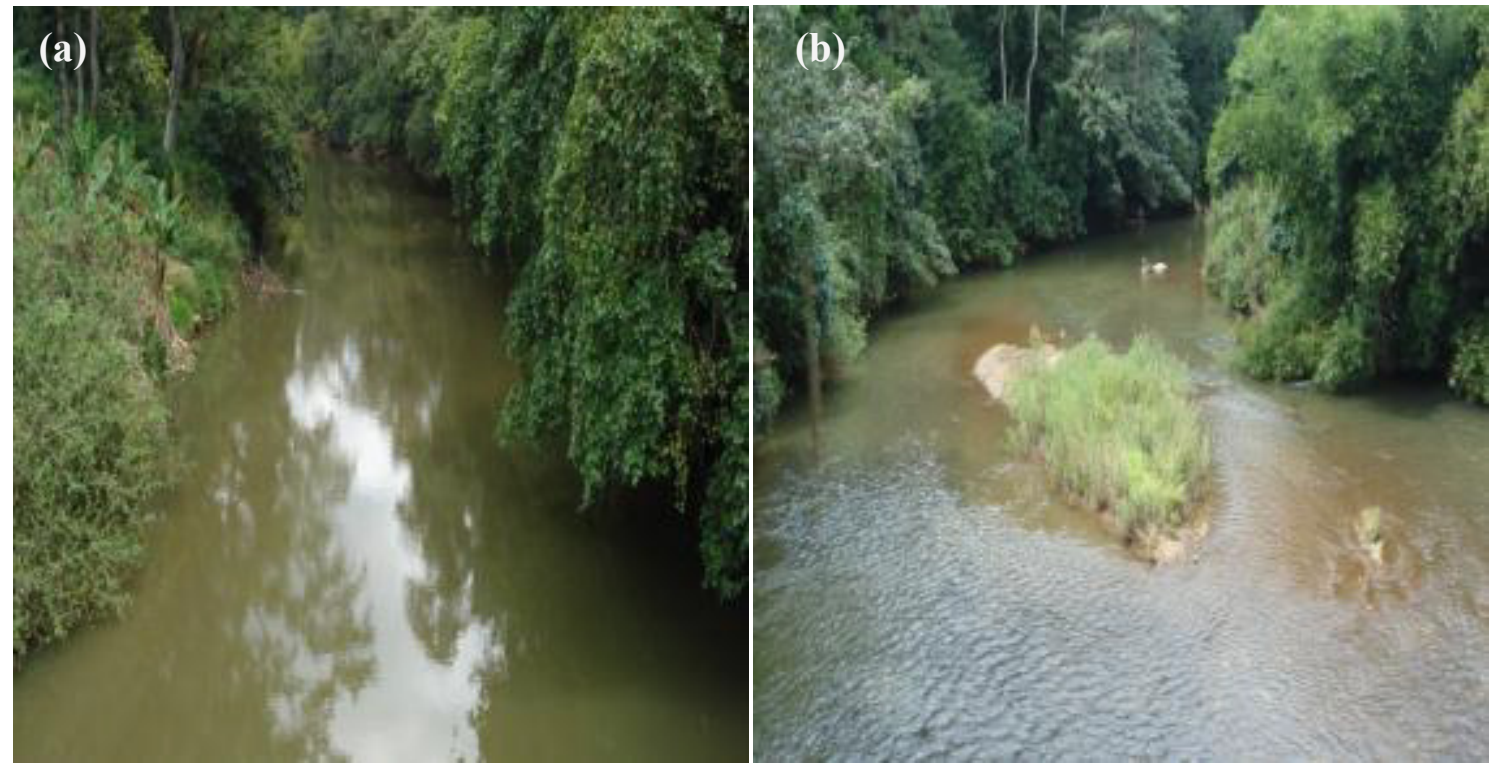

Figure 3.5. Ruvu River at Kibungo bridge during dry season (a) Upstream (b) Downstream 


\subsection{Geology and Soil types}

The geology of the catchment is influenced by Precambian Usagarian system that has suffered different plutonic histories and Neogene. The area contains Jurrassic, Karoo, Neogene and Quaternary strata in some parts of catchment (Gomani et al., 2010). There are different types of soil in the upper River basin that varies in texture from sand to clay. The different soil types in the upper River basin were classified as per the Soil Terrain Database of East Africa (SOTER) classification. The main soil orders are Fluvisols, Cambisols, Leptosols, Acrisols, Ferralsols and Vertisols. The spatial distribution of major soil types in the catchment with particle size percentage and organic matter content are shown in Figure 3.6 and Table 3.2. 


\section{Soils variation in watershed}

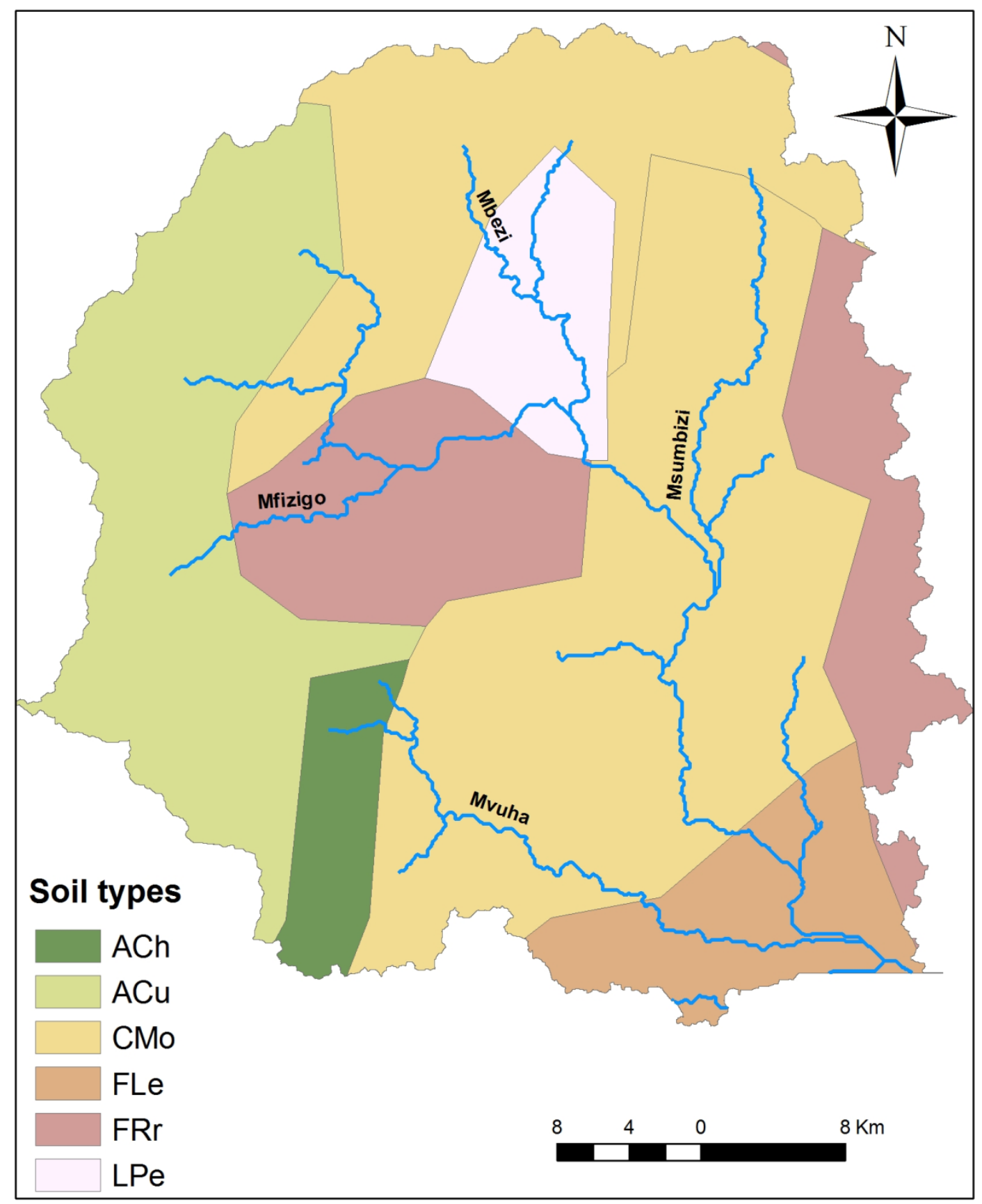

Figure 3.6. Soil classifications in the Kibungo watershed 
Table 3.2. Major soils ypes, particle size distribution and their area coverage in upper

Ruvu catchment

\begin{tabular}{|c|c|c|c|c|c|c|c|c|c|}
\hline $\begin{array}{l}\text { Soil } \\
\text { Code }\end{array}$ & Soil Type & $\begin{array}{c}\text { Gravel } \\
(\%)\end{array}$ & $\begin{array}{c}\text { Sand } \\
(\%)\end{array}$ & $\begin{array}{l}\text { Silt } \\
(\%)\end{array}$ & $\begin{array}{l}\text { Clay } \\
(\%)\end{array}$ & $\begin{array}{c}\text { Bulk } \\
\text { Density } \\
\left(\mathrm{Kg} / \mathrm{m}^{3}\right)\end{array}$ & $\begin{array}{c}\text { Organic } \\
\text { Matter } \\
(\%) \\
\end{array}$ & Texture & $\begin{array}{c}\text { Area } \\
(\%)\end{array}$ \\
\hline TZ28 & $\begin{array}{l}\text { Eutric } \\
\text { Fluvisols }\end{array}$ & 10 & 24 & 46 & 30 & 1.31 & 2.64 & $\begin{array}{l}\text { clay } \\
\text { loam }\end{array}$ & 1.7 \\
\hline TZ27 & $\begin{array}{l}\text { Ferralic } \\
\text { Cambisols }\end{array}$ & 16 & 51 & 10 & 39 & 1.33 & 1.73 & $\begin{array}{l}\text { sandy } \\
\text { clay }\end{array}$ & 8.2 \\
\hline TZ20 & $\begin{array}{l}\text { Rhodic } \\
\text { Ferralsols }\end{array}$ & 0 & 31 & 6 & 63 & 1.22 & 0.98 & $\begin{array}{c}\text { clay } \\
\text { (heavy) }\end{array}$ & 31.9 \\
\hline TZ11 & $\begin{array}{l}\text { Eutric } \\
\text { Leptosols }\end{array}$ & 0 & 46 & 26 & 28 & 1.36 & 3.13 & $\begin{array}{l}\text { clay } \\
\text { loam }\end{array}$ & 0.5 \\
\hline TZ6 & $\begin{array}{l}\text { Eutric } \\
\text { Planosols }\end{array}$ & 1 & 56 & 25 & 19 & 1.44 & 0.65 & $\begin{array}{l}\text { clay } \\
\text { loam }\end{array}$ & 1.3 \\
\hline TZ5 & $\begin{array}{l}\text { Eutric } \\
\text { Vertisols }\end{array}$ & 0 & 20 & 10 & 70 & 1.18 & 0.5 & $\begin{array}{c}\text { clay } \\
\text { (heavy) }\end{array}$ & 5.8 \\
\hline TZ14 & $\begin{array}{l}\text { Ferralic } \\
\text { Cambisols }\end{array}$ & 0 & 64 & 15 & 21 & 1.44 & 1.2 & $\begin{array}{c}\text { sand clay } \\
\text { loam }\end{array}$ & 10.8 \\
\hline TZ36 & $\begin{array}{l}\text { Humic } \\
\text { Acrisols }\end{array}$ & 10 & 43 & 15 & 42 & 1.3 & 2.53 & $\begin{array}{c}\text { clay } \\
\text { (light) }\end{array}$ & 15.8 \\
\hline TZ9 & $\begin{array}{l}\text { Eutric } \\
\text { Leptosols }\end{array}$ & 10 & 24 & 46 & 30 & 1.31 & 2.64 & lay loam & 0.4 \\
\hline TZ32 & $\begin{array}{l}\text { Haplic } \\
\text { Acrisols }\end{array}$ & 1 & 57 & 19 & 24 & 1.41 & 0.8 & $\begin{array}{c}\text { sandy } \\
\text { clay } \\
\text { loam }\end{array}$ & 7 \\
\hline TZ38 & $\begin{array}{l}\text { Eutric } \\
\text { Fluvisols }\end{array}$ & 0 & 46 & 26 & 28 & 1.36 & 3.13 & $\begin{array}{c}\text { clay } \\
\text { loam }\end{array}$ & 13.4 \\
\hline TZ13 & $\begin{array}{l}\text { Ferralic } \\
\text { Cambisols }\end{array}$ & 16 & 51 & 10 & 39 & 1.33 & 1.73 & sand clay & 3.1 \\
\hline
\end{tabular}

\subsection{Land use/cover}

The land cover in study area is characterized by various types of natural vegetation. Cultivation is the main land use activity in the catchment. A human settlement in most steep area is ranging from small towns to villages (Ngoye and Machiwa, 2004). Classification of land cover was adopted from other previous studies within the catchment. Land cover classification shapefiles from Institute of Natural 
Assessment (IRA)-University of Dar es Salaam were used in classifying land cover into six categories. The classification covered a 10-year period (1990 to 2000) at 3 intervals and natural forest, woodland, grassland, cultivated land, bushland and urban lands were present in the catchment (Figure 3.6). The bushland indicates the areas that are covered by grass and bush plant species, while woodland indicates a low-density forest forming open habitats with plenty of sunlight and limited shade.

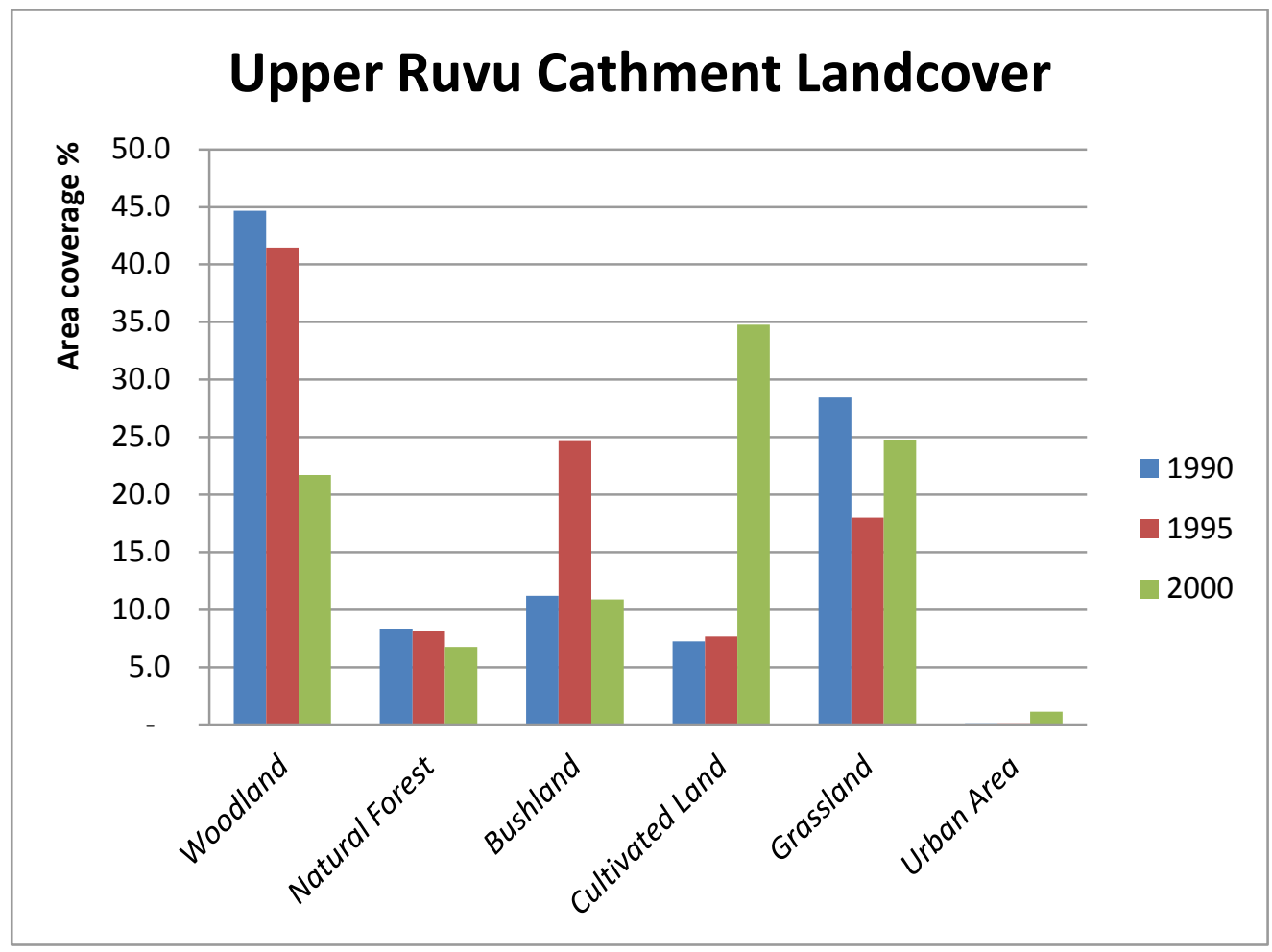

Figure 3.7. Land use changes classification in the upper Ruvu catchment

The percentage change in the area for each land cover group was calculated using a geographic information system (GIS) tool to visualize the change in land use of the study area as shown in Table 3.3, Figures 3.7and 3.8. The catchment seems to attract 
agriculture activities every year. As compared to 1990, the year 2000 showed significant change in cultivated lands. The area has soils with high in organic matter which produce main crops like crops are cereals, potato, maize and banana. Crops yield depending on climatic condition, soil fertility and agriculture management practices.

Table 3.3. Periodic Land use/land cover changes percentage in upper Ruvu catchment

\begin{tabular}{|l|l|l|l|l|l|l|}
\hline \multirow{2}{*}{$\begin{array}{l}\text { Land cover } \\
\text { Type }\end{array}$} & \multicolumn{2}{|c|}{$\mathbf{1 9 9 0}$} & \multicolumn{2}{c|}{$\mathbf{1 9 9 5}$} & \multicolumn{2}{c|}{$\mathbf{2 0 0 0}$} \\
\cline { 2 - 7 } & $\begin{array}{c}\text { Area } \\
\left(\mathbf{K m}^{\mathbf{2}}\right)\end{array}$ & $\mathbf{\%}$ & $\begin{array}{c}\text { Area } \\
\left(\mathbf{K m}^{\mathbf{2}}\right)\end{array}$ & $\mathbf{\%}$ & $\begin{array}{c}\text { Area } \\
\left(\mathbf{K m}^{\mathbf{2}}\right)\end{array}$ & $\mathbf{\%}$ \\
\hline Forest & 913 & 8.4 & 839 & 8.1 & 699 & 6.8 \\
\hline Agriculture land & 791 & 7.2 & 793 & 7.7 & 3590 & 34.8 \\
\hline Woodland & 4877 & 44.7 & 4287 & 41.5 & 2240 & 21.7 \\
\hline Grassland & 3105 & 28.4 & 1858 & 18.0 & 2557 & 24.8 \\
\hline Bushland & 1222 & 11.2 & 2548 & 24.6 & 1126 & 10.9 \\
\hline Urban Area & 11 & 0.1 & 14 & 0.1 & 116 & 1.2 \\
\hline
\end{tabular}




\section{Landuse/land cover 1990}

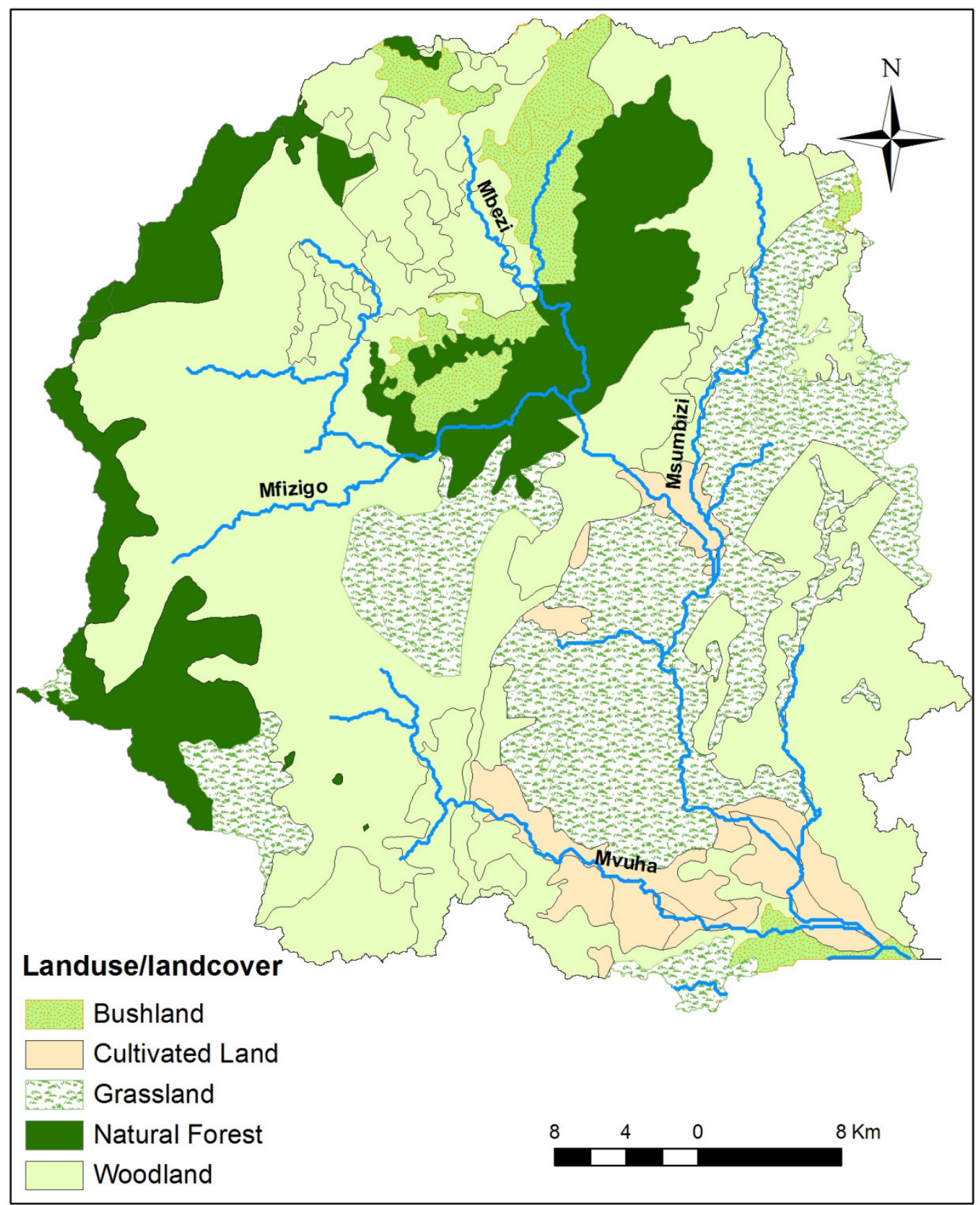

Figure 3.8. Land use/cover of 1990 in Kibungo watershed from where? 


\section{Landuse/land cover 2000}

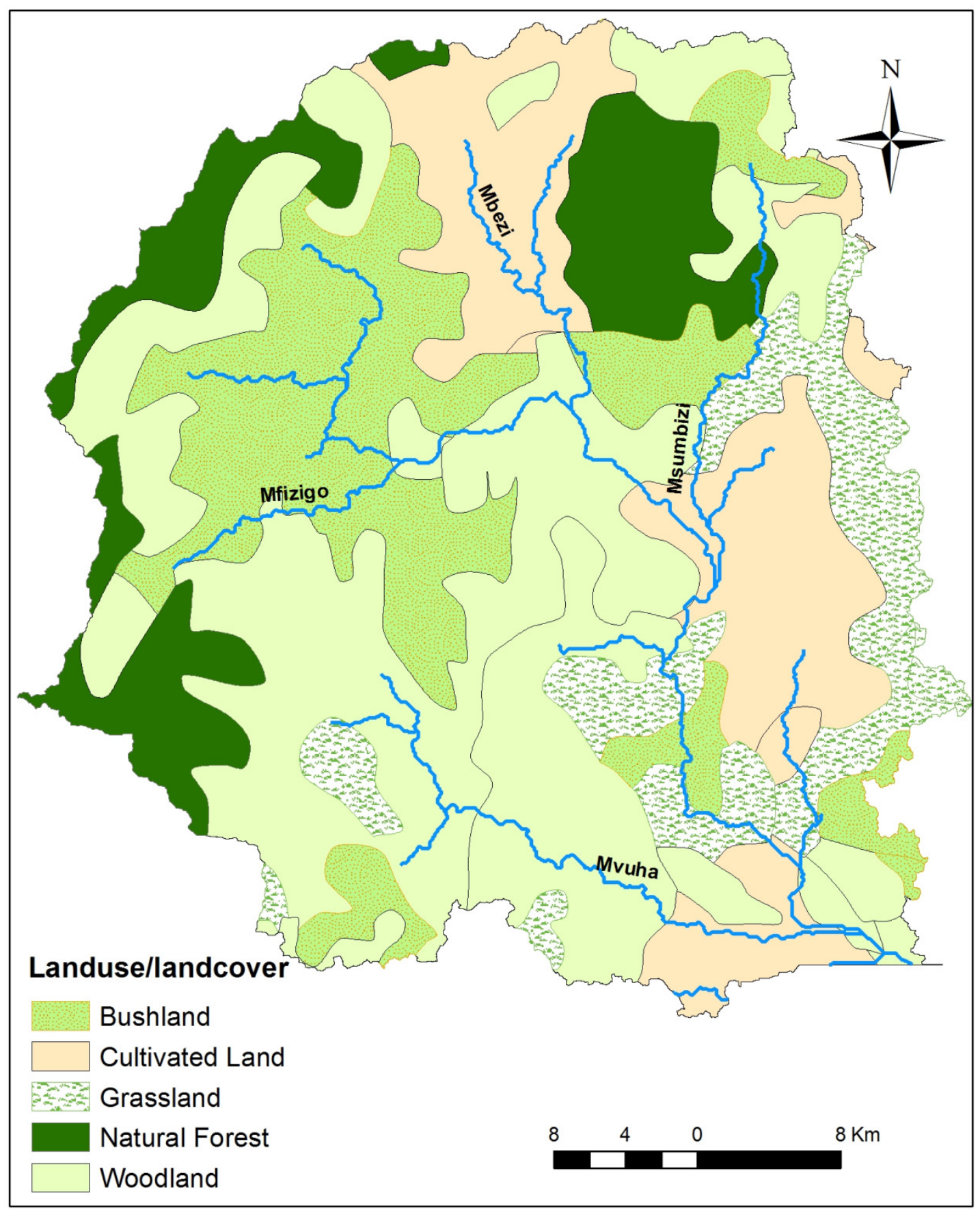

Figure 3.9. Land use/cover of 2000 in Kibungo watershed 


\subsection{Population and Livelihood}

The population in the basin has been growing fast hence increasing the danger of pollution to this water resource. According to Tanzania Population Census Office report, every 10 years, the population in the catchment is doubling with areas residing in high slopes showing the most significant increase. Water pollution problems in the basin have been increasing due to presence of upland settlements in water sources (Figure 3.10-3.11) that do not have sound management practices. Most of the area is rural and suburban with agriculture as their main activities in the catchment. The expansion of cultivation has increased soil erosion in upstream and sedimentation in rivers.

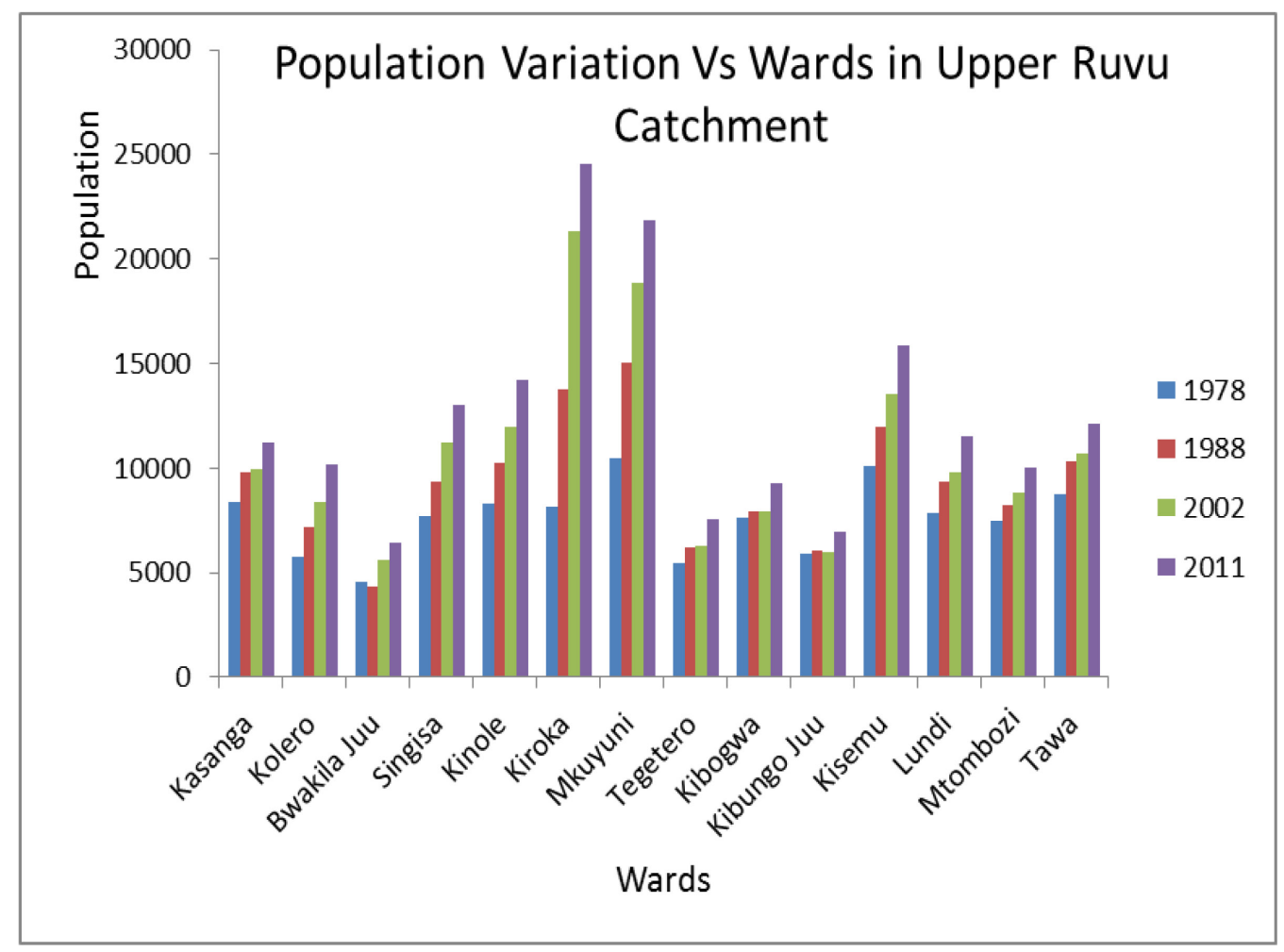

Figure 3.10. Population variation in upland wards within Kibungo watershed 


\section{Villages coverage in Kibungo}

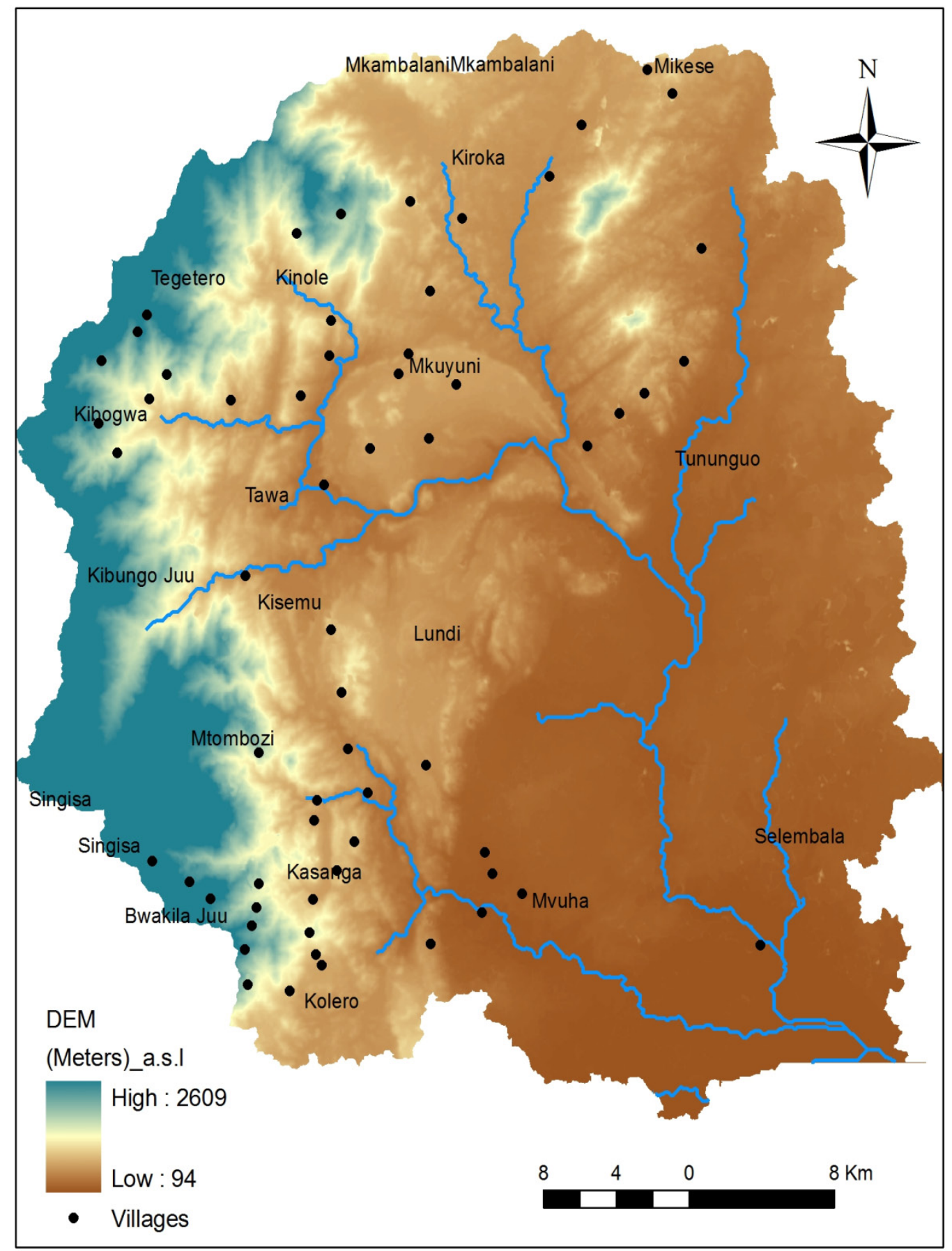

Figure 3.11. Villages' settlement increase towards high elevation in Kibungo watershed 


\subsection{Ecosystem Threats in Catchment}

The basin contains four blocks out of 13 Eastern Arc Mountains conservation blocks known in the world. These blocks have been used in several global analyses of biodiversity priority to show the most important areas of the world for the conservation of endemic birds, endemic plants and a combined set of taxonomic groups (Burgess et al, 2007). The major visible impact in the area is serious land mismanagement causing depletion of forest cover. Analysis of some previous studies shows that the forest area in the Uluguru Mountains declined from around $300 \mathrm{~km}^{2}$ in 1955 to $230 \mathrm{~km}^{2}$ in 2001, which was $<40 \%$ of the potential forest area (Burgess et al., 2002). Upper Ruvu catchment is characterized by major ecosystem needs from the upstream towards downstream. The area comprises of the Seloul Game Reserve, Uluguru Forest Reserves and Mikumi National Park which cover $897 \mathrm{~km}^{2}, 708 \mathrm{~km}^{2}$ and $908 \mathrm{~km}^{2}$, respectively. They have the internationally agreed protected area code IUCN II and are managed by the Tanzania National Parks Authority (TANAPA).

Uruguru Mountains in the catchment are globally recognized for biodiversity conservation. They are ranked $15^{\text {th }}$ highest for bird fauna and sixth for all vertebrates (Bhatia and Buckley, 1998). There are three important species of mammals on the IUCN Red list, three species of reptiles that are Uluguru endemics and 10 of 22 forest species of Eastern Arc endemics. Also, six amphibians endemics to the Uluguru and 10 out of 37 species of butterflies in Eastern Arc conservation area makes this catchment to be most important to regulatory authority. At present, new species are still being discovered regularly where-ever intensive biological studies are undertaken. For example the 
Kihansi Spray Toad was only discovered in 1996 during environmental monitoring work for the Lower Kihansi Hydropower Project in the southern Udzungwa Mountains (Poynton et al., 1998). Lovett and Wasser (1993) and Burgess et al. (1998) in their study of Eastern Arc blocks indicates that, Mt. Ulugurus alone possess 13 endemic vertebrates' species and 169 endemic invertebrate species endemic to that mountain alone. This implies the water quality of basin to be protected for aquatic ecosystem health and water resources sustainability.

The water quality records at the catchment outlets should be representative of the catchment conditions. Also the permanent Ruvu Kibungo flow gauging stations with historical stream flow measurement has been regarded as indicator of flow changes in the catchment.

\subsection{Water quality Management}

The National Water Policy (NAWAPO, 2002), in which five main levels of management was set (National, Basin, Catchment, District level and Community) and the National Water Sector Development Strategy (NWSDS, 2006) are main two management guidelines in water sector. There are also several laws (ordinances, acts, regulations, subsidiary legislations, and by-laws) that in one way or another deal with water quality and environment conservation. In 2009, the Water Resources Management Act was enacted with the objective of ensuring that the nation's water resources are protected, used, managed, developed and conserved sustainably. This new water legislation repealed the Water Utilization (Control and Regulation) Act Cap 331 and Water Works 
Act, Cap 272, respectively and therefore considerably changed the formation of the existing legal and Institutional framework. The Water Resources Department in the Ministry of Water and Basin office has the authority of managing water resources including monitoring water quality. The Water basin in collaboration with catchment Water offices, sub-catchments water users and Water Users' Associations at Village level are the main stakeholders to implement and enforce these laws.

Currently, the establishment of Water Users Associations (WUA's) at village level is going on in conjunction with establishment of District Facilitation Teams (DFT's) in each district to train and supervise the WUA's. The WUA's under Local Government institution are reporting to village governments resulting in a more streamlined approach to submitting reports the District Level and not Wami-Ruvu basin which is central government. Education and building awareness on conservation issues in relation to watershed management techniques is implemented by the both Wami-Ruvu basin and DFT's. This includes community participation and informing them of their responsibilities as stipulated by NAWAPO and Water Resource Management Act, 2009. Plans at district and local level are promising. For example, in Kondoa District, the village governments have created some by-laws stating that nobody can disturb the water resources and surrounding, this include not cutting trees and protecting cattle from entering (Ngana et al.,2010). 


\subsection{METHODOLOGY}

This chapter describes collection and analysis of various data that are used as input to the WEPP model. First, reconnaissance field survey was carried out from June 17, 2011 to June 19, 2011 with a combination of maps in order to decide which sub-basin or catchment to be studied. Field observation was used to collect preliminary data of landuse, soil erosion situation and streams or riverbanks characteristics. Twenty five agricultural extension workers and five farmers inside management project area (CARE) and outside management area were interviewed to assess their agricultural management practices. Also field update of landuse was taken by GPS to enhance classification. The following wards were visited; Kisaki-Gomero, Kiroka, Kinole, Kibogwa, Mkuyuni, Tawa, Tununguo Lundi, Mtombozi, Mtamba, Kibungo Juu, Kolero, Mngazi, Doma, Mlali, Tchenzema, Bunduki and Langali. In order to achieve the intended objectives of this study, various experimental and detail scientific methods were followed as described in the next sections of this chapter.

\subsection{GIS and WEPP Modeling procedure}

WEPP is process-based model on modern hydrological and erosion science. It calculates runoff and erosion on daily basis (Baigorria, 2007). The model compared with USLE/RUSLE and chosen to be used in study because its capability to integrate different factors that governs erosion process. Its simulations can be enhanced by using digital sources of information through the linkage with GIS. WEPP designed for hill-slope areas/watersheds. Advantages of using WEPP model are: 1) ability to estimate spatial and 
temporal distributions of net soil loss, 2) more accurate extrapolation to un-gauged sites, and 3) an enhanced ability to predict sediment yield including particle size information. The GeoWEPP model is a geo-spatial erosion prediction model developed to incorporate advanced GIS features (ArcGIS software and its Spatial Analyst Extension) to extract essential model input parameters from digital data sources.

\subsection{Model Inputs}

GeoWEPP is designed to integrate four different data for accuracy of WEPP process-based model. The main inputs include topography, soil, landuse and climate information while the basic maps required should be in ASCII formats exported by ArcGIS. The scales and resolution of the spatial inputs can vary according to the variable. In this study, requirements were in accordance to GeoWEPP for ArcGIS 9.x Full Version Manual for GeoWEPP Version 2.2008 downloaded at University of New York (SUNY) supported and funded by US Department of Agriculture-Forest Service (USDA-FS) and other federal agencies. This is the research project at Landscape-based Environmental System Analysis \& Modeling (LESAM)

(http://www.geog.buffalo.edu/ rensch/geowepp/arcgeowepp/GeoWEPP\%20for\%20Arc GIS\%209\%20Manual.pdf). The model used for this study was WEPP Model Version 2010.1 (weppwin 01 - 28-2010) interfaced with ArcGIS version 9.3.2.

The GeoWEPP package includes two tools that further expand its utility. These are the Topographic Parameterization tool (TOPAZ) and Topwepp software products developed by the USDA-ARS. The TOPAZ generates hillslope profiles by parameterizing topographic data using a given DEM. This process provides the needed 
input data for the subsequent delineation of a watershed, sub-catchments, flow direction determination and channel network generation. Topwepp uses grid based information stored in the raster layers of the land cover, soil and land use management to execute the model runs and produces the output maps. The methodology flow chart used in this study is illustrated in Figure 4.1.

\section{WEPP MODEL FLOW CHART}

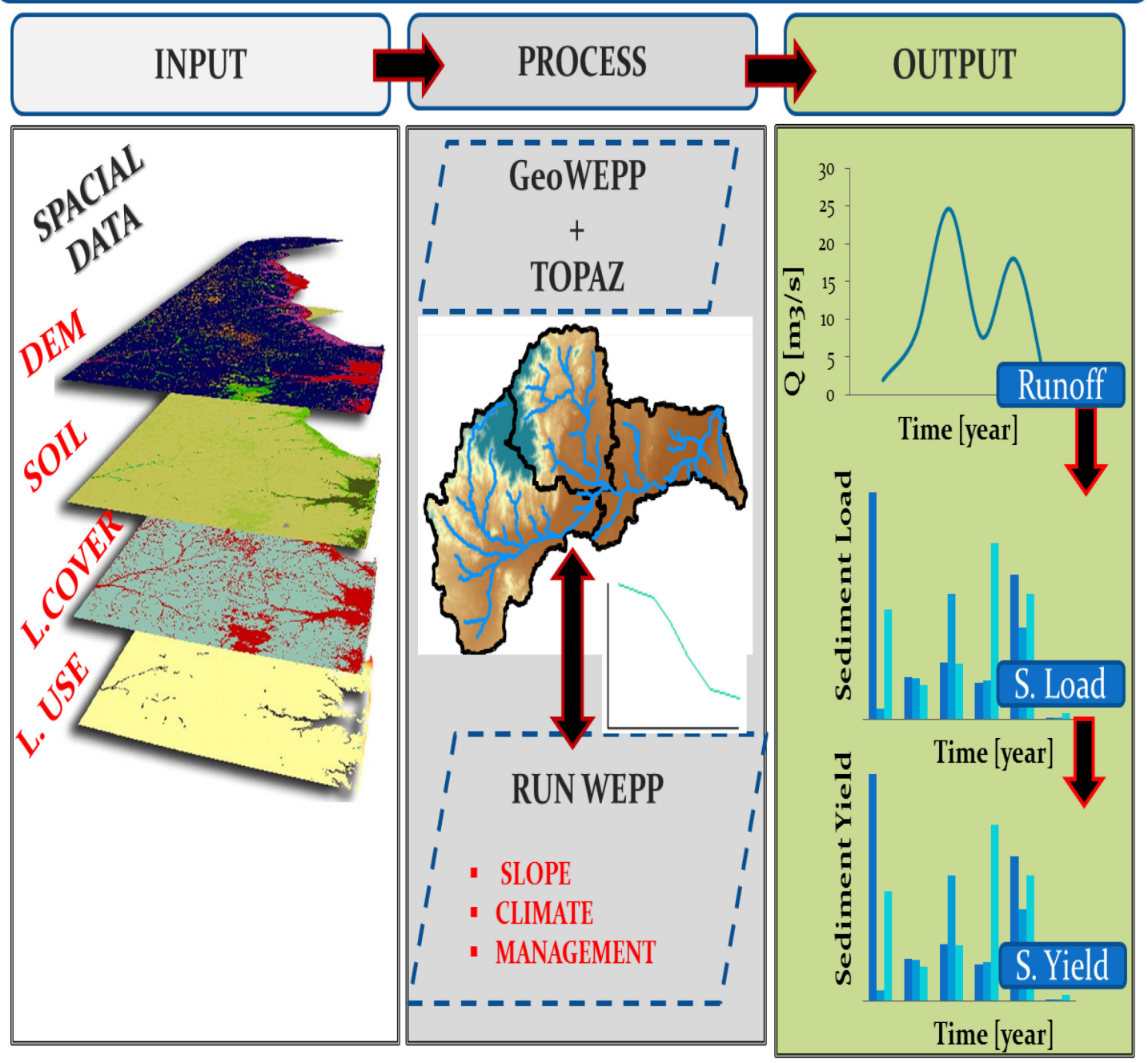

Figure 4.1. Flow chart of WEPP model Simulation 


\subsubsection{Topography}

The topography variables are altitude and slope. The Digital Elevation Model (DEM) of 30m x 30m was downloaded from ASTER Global Digital Elevation Model (ASTER GDEM) website. The ASTER GDEM was used because of its easy use of topographic information of the global terrain acquired by a satellite-borne sensor "ASTER" to cover all the land on earth. A polygon representing study area was used to extract study area DEM from original dataset using Spatial Analysts Tool. The advantage of using this high resolution of $30 \times 30$ is its applicability for GeoWEPP modeling. Figure 4.2 shows the slopes values of the study area in percent and existing rivers used to delineate sub-watersheds in GeoWEPP. The projected DEM was changed to raster format and then converted it to ASCII format using ASCII conversion tool in ArcToolbox of ArcGIS. The file saved as dem-geowepp.asc in Data Preparation folder. 


\section{Slopes variation in watershed}

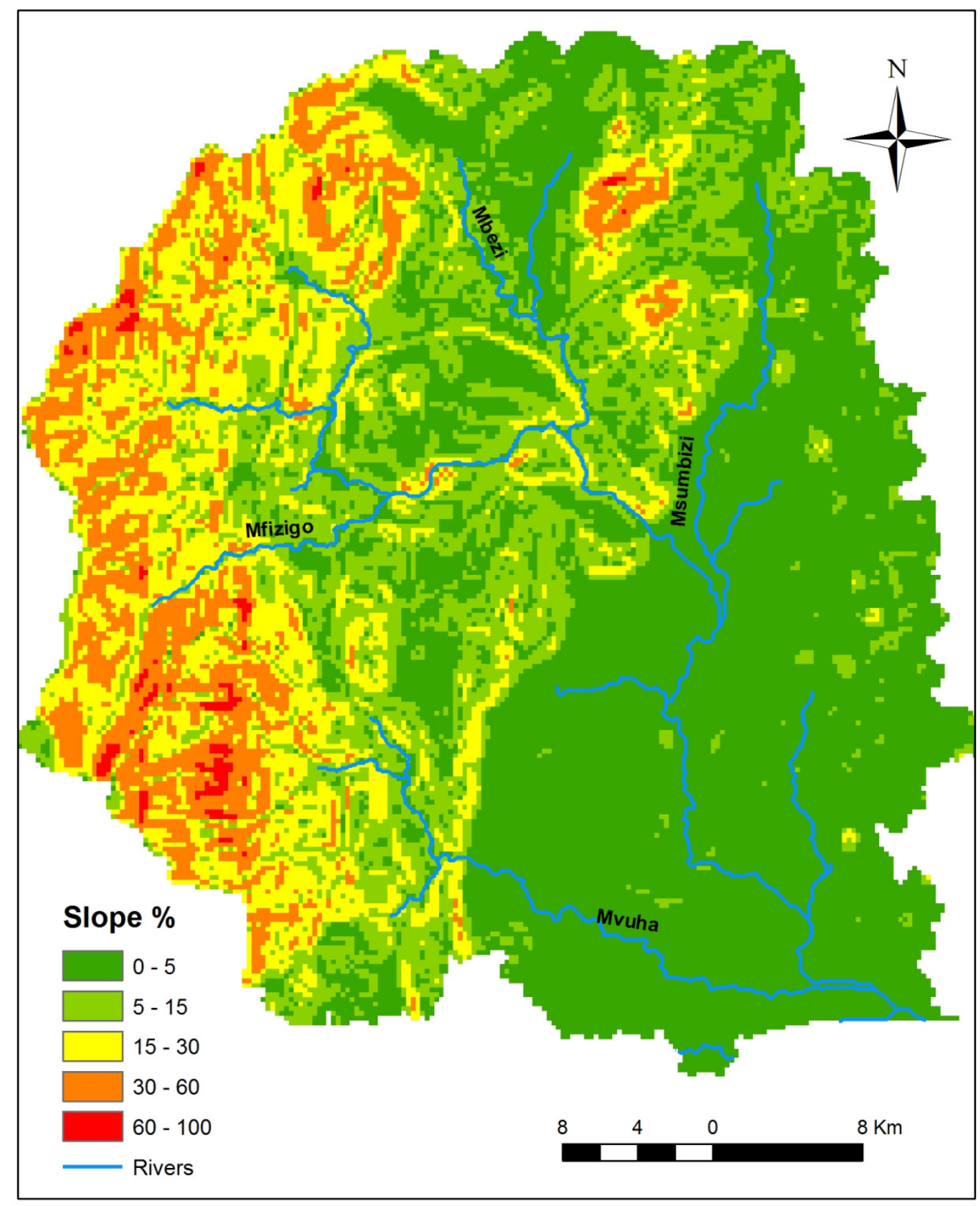

Figure 4.2. Slope map of the study area 


\subsubsection{Soil Data}

Soil map of the study area was downloaded from the Harmonized World Soil Database (HWSD) from FAO with scale of 1: 2,000,000. The data were in TIFF format converted to GRID and re-projected in similar cell size and resolution of DEM and then converted to shape file. There are three essential soil files required in the model includes ASCII format and two text files format one saved as txt file and another as $d b$ file. The interest was to leave "MU-SOURCE 90" the global code which links the shape files to soil data stored in other files. The shape file was converted to raster format then converted to ASCII format stored in the Data Preparation folder as soil_geowepp.asc. The soil data, the soilmap.txt and soilmapdb.txt were created with the map unit key and the map unit symbol corresponding to the raster value and description, respectively while the soil type was specified with the appropriate (.sol) file in the folder containing WEPPs soil database (Figure 4.3 and Table 4.1).
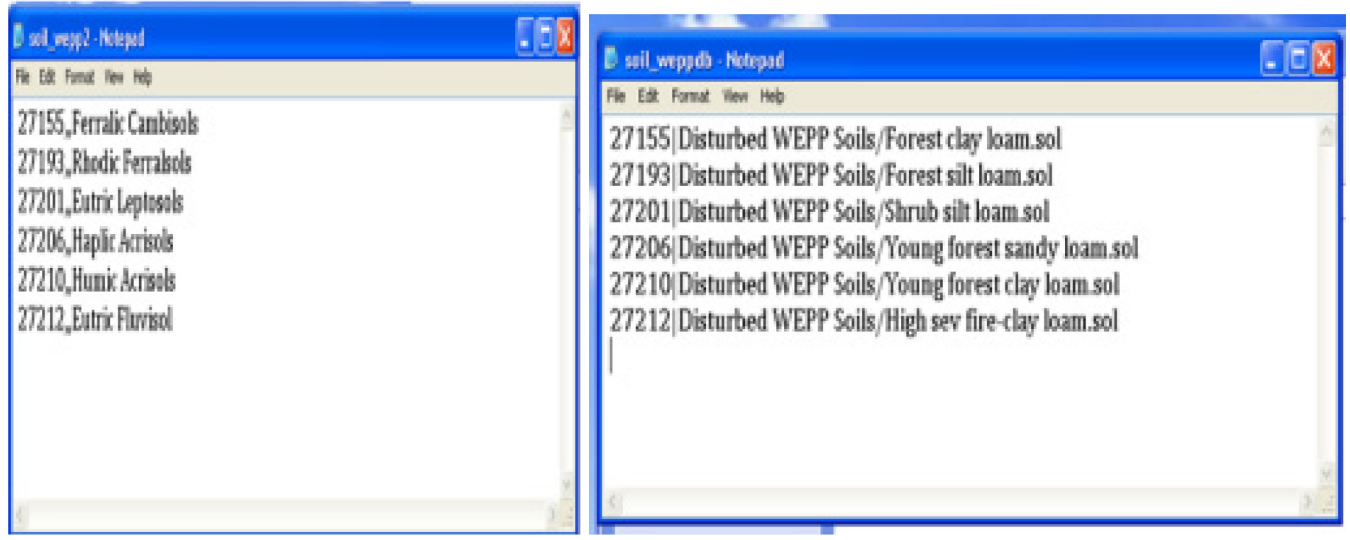

Figure 4.3. Print screens shows the text bridges for the soils data 
Table 4.1. Soil text files for soil types and properties for WEPP model

\begin{tabular}{|l|l|l|l|}
\hline \multicolumn{2}{|c|}{ Soilmap.text } & \multicolumn{2}{c|}{ Soilsdb.text } \\
\hline $\begin{array}{l}\text { Raster Value: } \\
\text { Mu_Source90 }\end{array}$ & \multicolumn{1}{|c|}{$\begin{array}{l}\text { Description } \\
\text { (Su_Smy90) }\end{array}$} & \multicolumn{2}{c|}{ Description and Soil Type } \\
\hline 27155 & $\begin{array}{l}\text { Ferralic } \\
\text { Cambisols }\end{array}$ & 27155 & $\begin{array}{l}\text { Disturbed WEPP Soils/Forest clay } \\
\text { loam.sol }\end{array}$ \\
\hline 27193 & Rhodic Ferralsols & 27193 & $\begin{array}{l}\text { Disturbed WEPP Soils/Forest silt } \\
\text { loam.sol }\end{array}$ \\
\hline 27201 & Eutric Leptosols & 27201 & $\begin{array}{l}\text { Disturbed WEPP Soils/Shrub silt } \\
\text { loam.sol }\end{array}$ \\
\hline 27206 & Haplic Acrisols & 27206 & $\begin{array}{l}\text { Disturbed WEPP Soils/Young } \\
\text { forest sandy loam.sol }\end{array}$ \\
\hline 27210 & Humic Acrisols & 27210 & $\begin{array}{l}\text { Disturbed WEPP Soils/Young } \\
\text { forest clay loam.sol }\end{array}$ \\
\hline 27212 & Eutric Fluvisols & 27212 & $\begin{array}{l}\text { Disturbed WEPP Soils/High sev } \\
\text { fire-clay loam.sol }\end{array}$ \\
\hline
\end{tabular}

\subsubsection{Landcover Data}

High percentage change of land cover from 1990 to 2000 caused by agriculture and settlement was observed. The 1990 land use/land cover used in simulation considered as pre-settlement period to give snap shot erosion effects at that period. The shape files converted to raster format making sure the projection and cell size are similar with DEM and then exporting the attribute table values to text file. The file stored as landcover_.txt in GeoWEPP Data Preparation folder. The raster also was converted to ASCII format and stored as landcover_wepp.asc in the same folder. Figure 4.4 and Table 4.2 show preparation of land use management practice done according to GeoWEPP manual. In order to link land cover with WEPP parameters, the landcover text file was saved as $d b$ file and deleting all the information remaining with value that links with other file. 


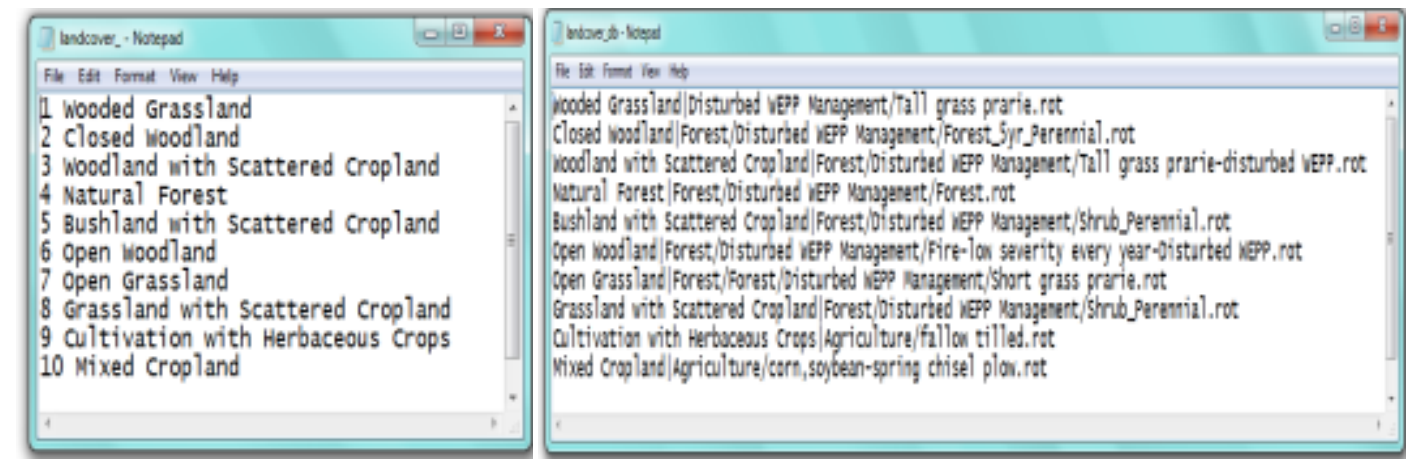

Figure 4.4. Print screen shows the text bridges for the land use/land cover data

Table 4.2. Landuse/land cover and management text files for WEPP model

\begin{tabular}{|l|l|}
\hline $\begin{array}{c}\text { Raster } \\
\text { Value }\end{array}$ & \multicolumn{1}{|c|}{ Land use/land cover |Management Description } \\
\hline 1 & Wooded Grassland|Disturbed WEPP Management/Tall grass prarie.rot \\
\hline 2 & Closed Woodland|Forest/Disturbed WEPP Management/Forest.rot \\
\hline 3 & $\begin{array}{l}\text { Woodland with Scattered Cropland/Forest/Disturbed WEPP } \\
\text { Management/Tall grass prarie-disturbed WEPP.rot }\end{array}$ \\
\hline 4 & $\begin{array}{l}\text { Natural Forest|Forest/Disturbed WEPP } \\
\text { Management/Forest_5yr_Perennial.rot. }\end{array}$ \\
\hline 5 & $\begin{array}{l}\text { Bushland with Scattered Cropland/Forest/Disturbed WEPP } \\
\text { Management/Shrub_Perennial.rot }\end{array}$ \\
\hline 6 & $\begin{array}{l}\text { Open Woodland|Forest/Disturbed WEPP Management/Fire-low } \\
\text { severity every year-Disturbed WEPP.rot }\end{array}$ \\
\hline 7 & $\begin{array}{l}\text { Open Grassland/Forest/Forest/Disturbed WEPP Management/Short } \\
\text { grass prarie.rot }\end{array}$ \\
\hline 8 & $\begin{array}{l}\text { Grassland with Scattered Cropland/Forest/Disturbed WEPP } \\
\text { Management/Shrub_Perennial.rot }\end{array}$ \\
\hline 9 & Cultivation with Herbaceous Crops|Agriculture/fallow tilled.rot \\
\hline 10 & Mixed Cropland|Agriculture/corn, soybean-spring chisel plow.rot \\
\hline
\end{tabular}

\subsubsection{Climate Data}

Monthly climate data for the study area was obtained from Tanzania Meteorological Agency (TMA) and Morogoro Weather station at Wami Ruvu Basin Office (WRB) as recorded in 10 stations. Stations selected were those within or near the 
study area and with 30 or more years (between 1950 and 2005) of monthly and some with daily data acquired for further processing. Maximum and minimum daily temperatures and precipitation depths are required as model inputs. The data were analyzed by Parameter-elevation Regressions on Independent Slopes Model (PRISM) tool which allows modification of an existing WEPP Climate parameter file - the files WEPP uses to generate the climate events for a simulation. PRISM allows this modification to the WEPP climate parameter files so that it can more closely match the climate found in area of interest (Minkowski and Reschler, 2008). The information in PRISM files are monthly temperature, precipitation and wet days. Also there is climate station name, elevation and its location (latitude and longitude). For the study area, average monthly rainfall measurements from all stations were converted to inches (Table 4.3) to allow comparable modification process.

Table 4.3. Average monthly rainfall (inches) for PRISM modification model

\begin{tabular}{|l|c|c|c|c|c|c|c|c|c|c|c|c|}
\hline $\begin{array}{l}\text { Station } \\
\text { Name }\end{array}$ & Jan & Feb & Mar & Apr & May & Jun & Jul & Aug & Sep & Oct & Nov & Dec \\
\hline Mikula & 2.8 & 1.89 & 5.44 & 7.53 & 2.36 & 0.63 & 0.28 & 0.39 & 0.79 & 0.75 & 2.29 & 3.74 \\
\hline $\begin{array}{l}\text { Ng'hesse } \\
\text { Utari }\end{array}$ & 3.27 & 2.88 & 4.45 & 6.23 & 3.07 & 0.59 & 0.28 & 0.59 & 0.87 & 2.36 & 3.35 & 3.47 \\
\hline $\begin{array}{l}\text { Singisa } \\
\text { Mission }\end{array}$ & 6.03 & 6.11 & 10.91 & 17.02 & 7.56 & 1.58 & 0.95 & 0.67 & 1.26 & 1.85 & 4.41 & 5.56 \\
\hline Kisaki & 3.86 & 2.92 & 6.5 & 9.14 & 5.36 & 0.95 & 0.43 & 0.55 & 0.51 & 0.95 & 1.69 & 2.09 \\
\hline $\begin{array}{l}\text { Duthumi } \\
\text { Estate }\end{array}$ & 4.49 & 4.26 & 7.33 & 10.05 & 4.41 & 1.06 & 0.47 & 0.35 & 0.79 & 1.02 & 2.76 & 3.19 \\
\hline Mtamba & 5.87 & 5.83 & 9.34 & 10.64 & 4.37 & 1.46 & 2.17 & 1.02 & 2.64 & 4.69 & 5.67 & 8.94 \\
\hline $\begin{array}{l}\text { Morning } \\
\text { Side }\end{array}$ & 5.91 & 5.32 & 10.4 & 20.09 & 11.7 & 4.02 & 3.55 & 3.31 & 3.62 & 5.87 & 8.2 & 7.41 \\
\hline $\begin{array}{l}\text { Matombo } \\
\text { Mission }\end{array}$ & 8.27 & 6.86 & 11.82 & 12.25 & 5.75 & 2.44 & 2.44 & 2.32 & 2.48 & 3.59 & 5.71 & 7.88 \\
\hline $\begin{array}{l}\text { Kibungo } \\
\text { Maji }\end{array}$ & 7.33 & 5.59 & 8.94 & 11.94 & 4.96 & 2.01 & 1.58 & 1.22 & 1.97 & 3.86 & 5.32 & 8.2 \\
\hline Hobwe & 4.57 & 4.61 & 6.86 & 9.57 & 3.98 & 0.63 & 0.39 & 0.28 & 0.83 & 1.85 & 3.35 & 4.14 \\
\hline
\end{tabular}


The climate modification window is broken into two sections; left and right side. The left side of the Climate Modification window contains the data found in the current selected climate station's parameter file. The right side of the window is almost exactly the same as the left side, with one major exception that allows modification of contained values (Figure 4.5). Therefore, the values displayed on the right side were changed any to be more closely and match with study area's climate data.

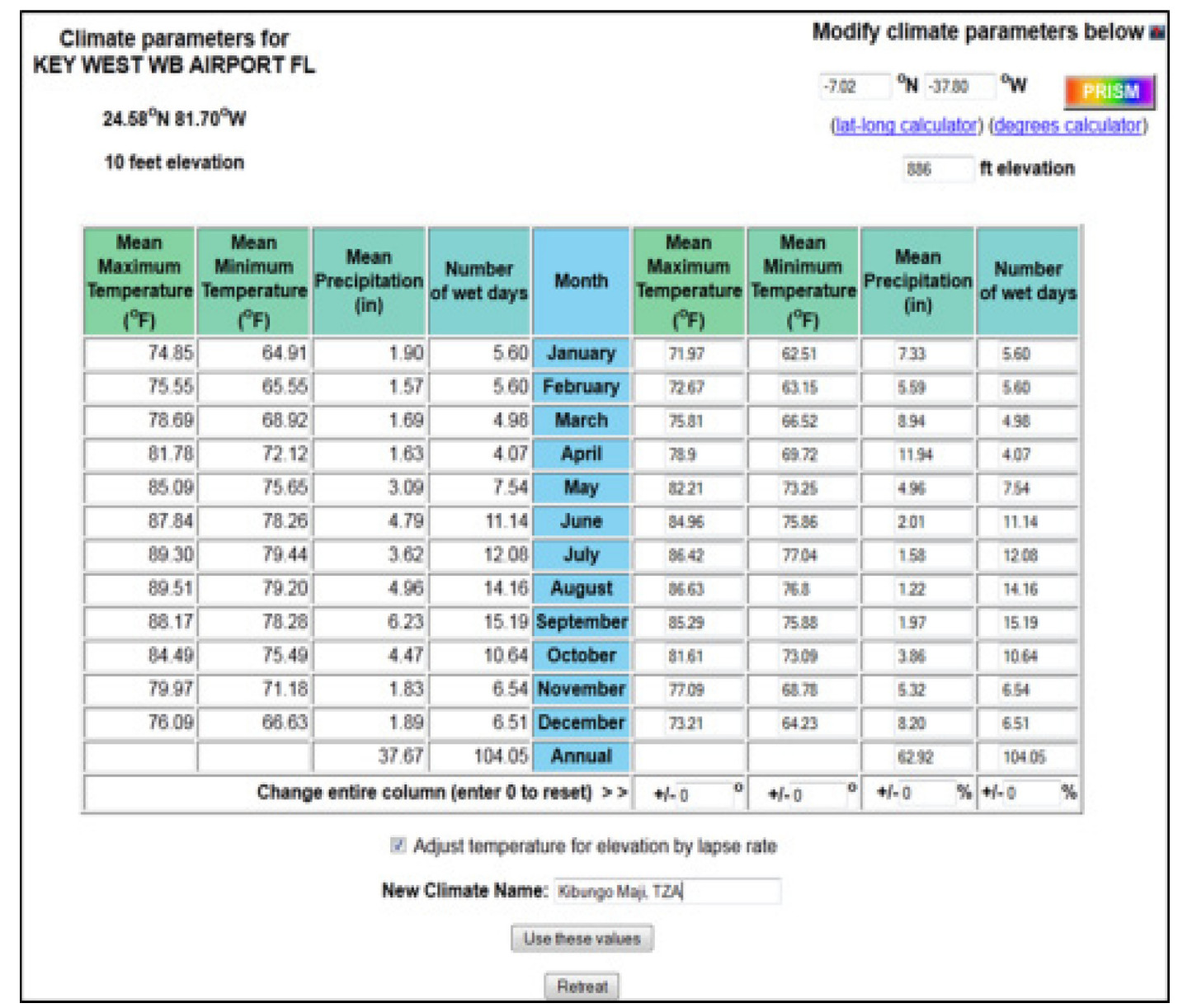

Figure 4.5. WEPP model Climate data modification window at Rock climate Interface. Source: (Scheel et al,. 2001, Minkowski and Reschler, 2008) 
All the values changed by clicking the boxes and enter exact new values or by specifying a percent increase or decrease over values at existing station. Modification on temperature was based on Lapse Rate change option by checking lapse rate box at the bottom window. This adjustment is based on the change of elevetaion from climate station information on the left and changes in the elevation in study area. All the climate input were processing by World CLImate GENerator (CLIGEN) program as recommended for WEPP simulation.

\subsection{Model Run}

There are three main steps of running model before WEPP simulation to be conducted. Model run was done through the GeoWEPP Wizard, where by the first step was loading of different layers of GIS input data (DEM, soil map, and land cover all in ASCII format). The second step was running of TOPAZ tool to delineate network channels followed by sub-watershed (hillslope) generation, and finally simulation method selection. All these model steps are discussed in the following sections.

\subsubsection{Drainage network delineation}

Channel network in GeoWEPP was generated based on DEM using two parameters; the Critical Source Area (CSA) and the Minimum Source Channel Length (MSCL). Both of these parameters depend on the DEM resolution. The CSA is the minimum source area needed to generate a channel and MSCL is the shortest distance; a first order channel needs to travel before it converges with another channel. As in other GeoWEPP run, there is Modify Channel Network Delineation tool that allows 
modification of default CSA and MSCL values. According to study area resolution of $30 \mathrm{~m} \times 30 \mathrm{~m}, 50$ hectares for the CSA and 1000 meters for the MSCL were used to get the channel network relating to study.

\subsubsection{Sub-watershed Delineation}

Sub-watershed delineation was done to select a channel cell as an outlet point. It is possible to select any channel cell to be the outlet point in the cell that have only one channel cell flowing into it. Each channel within the network will have up to three hillslopes flowing into it (left, right, and source). A maximum of 2,900 hillslopes and 1000 streams can be accommodated by a single model run (GeoWEPP Manual, Minskowski and Renschler, 2008). The resulting stream network greatly influences number of hillslopes, number of streams in watershed and the model simulation type to be used. The channel in GeoWEPP is considered as the part of the network that either starts with a head cell or a convergence cell that ends with the cell flows into a convergence cell or at the outlet point. According to model simulation limitations, four watershed outlet points were selected in major streams to partition the watershed into four sub-catchments based on size of the study area (Figures 4.6 to 4.9 ). The number of hillslopes and streams were calculated and checked before simulation to compare with model requirements. The names of sub-watershed were given to relate to the rivers/streams drained in particular sub-watershed. Mfizigo sub-watershed is drained by Mfizigo and Mbezi streams; Msumbizi is drained by Msumbizi stream while Mvuha subwatershed is mainly drained by Mvuha River. 


\section{Mfizigo Subwatershed Map}

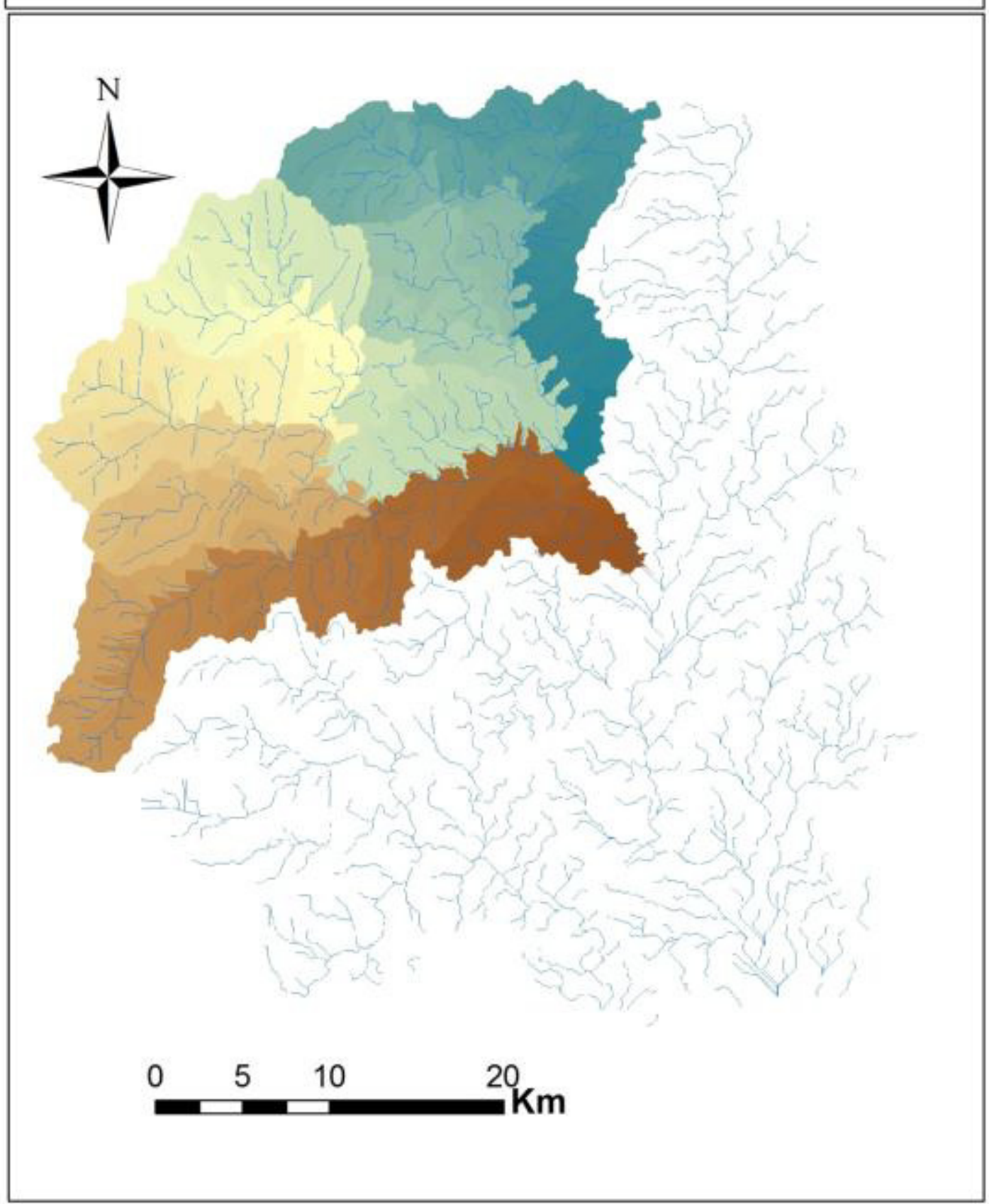

Figure 4.6. Mfizigo sub-watershed delinieated by WEPP model 


\section{Mvuha Subwatershed Map}

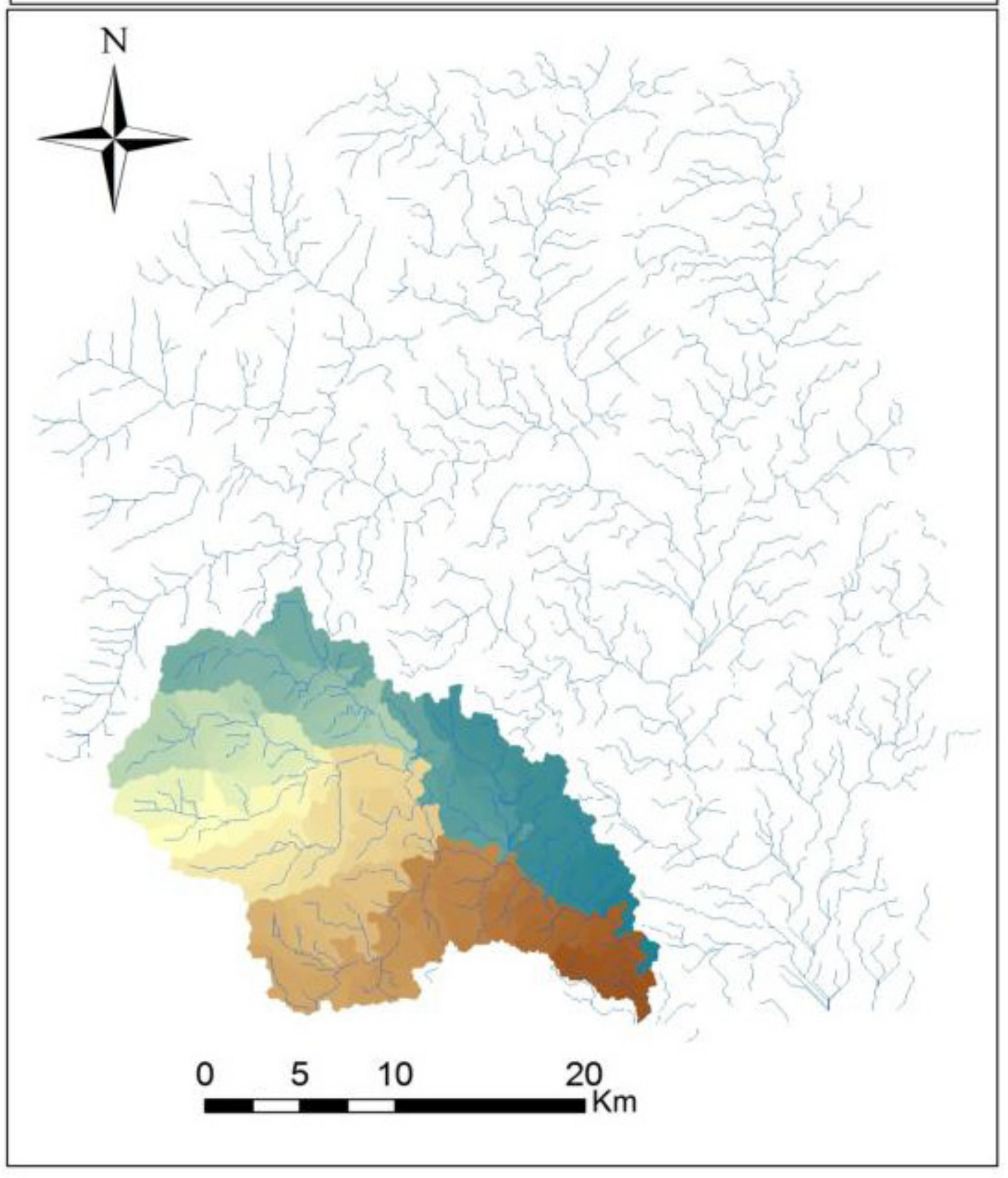

Figure 4.7. Mvuha sub-watershed delinieated by WEPP model 


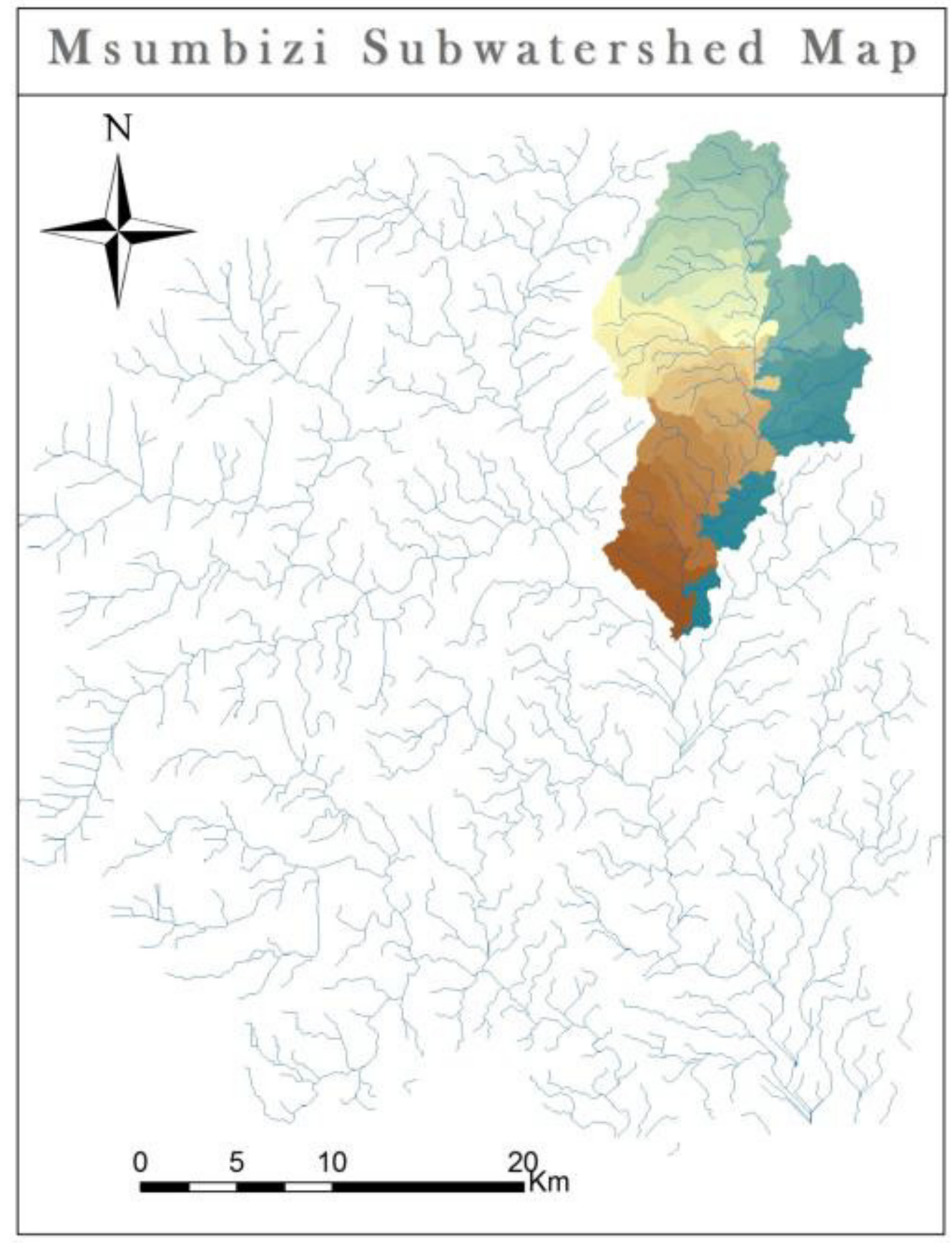

Figure 4.8. Msumbizi sub-watershed delinieated by WEPP model 
Kibungo Chini Subwatershed Map

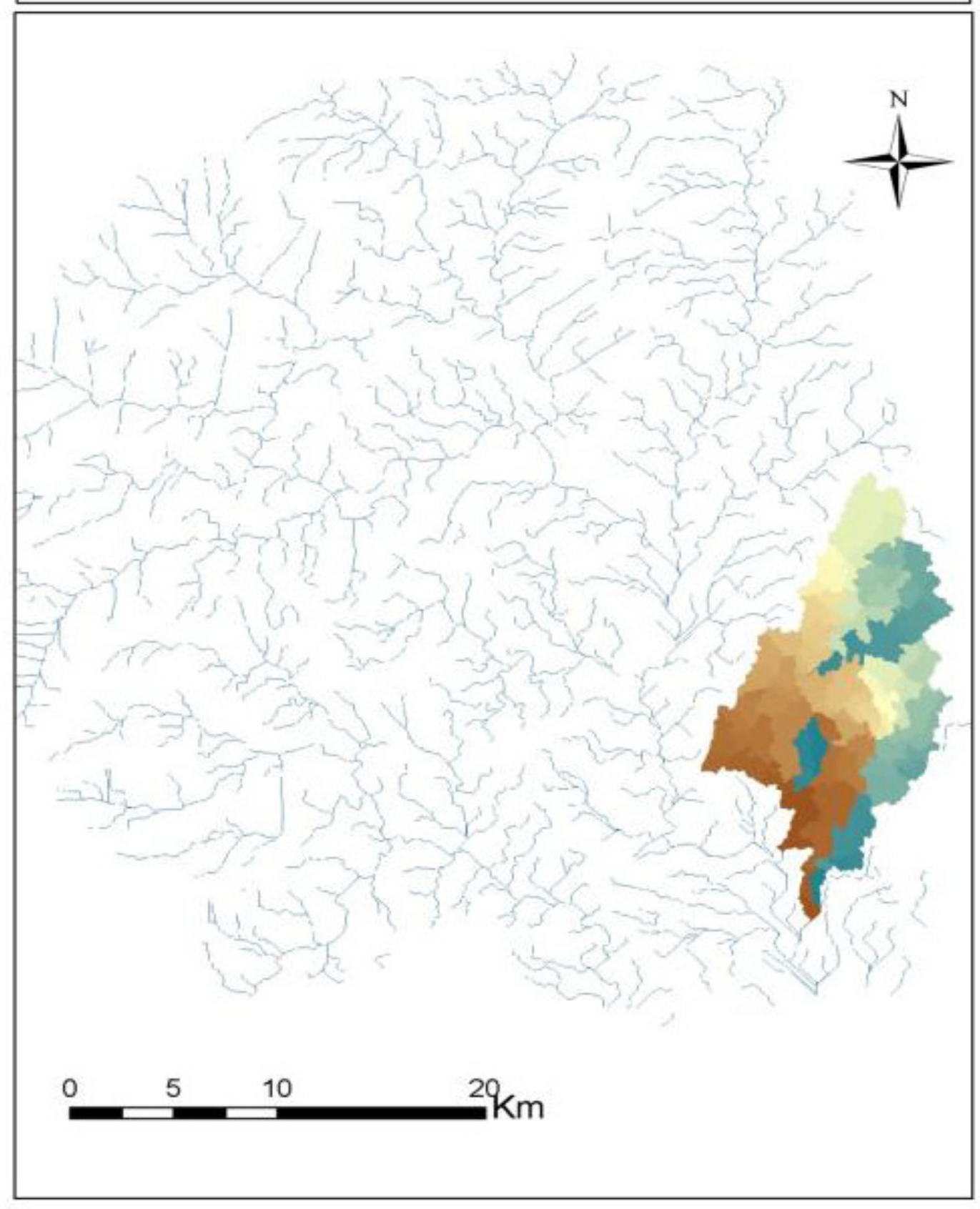

Figure 4.9. Kibungo chini sub-watershed delinieated by WEPP model 


\subsubsection{Simulation Method}

The three methods of simulations include Watershed, Flowpath or both. Watershed or Flowpath is used with simulation period varying from 2 to 30 years. The flow method concentrates on each flow within the sub-watershed keeping the diversity of soil and landuse layers. This method is also called on-site assessment because of values it reports refer to the amount of erosion or deposition in each cell of sub-watershed. In this study, watershed method was used for simulation because of size of the catchment. Within each sub-watershed, 30 years of simulation was used to report annual sediment yield leaving each hillslope and channel at the outlet point.

\subsection{Modification of Inputs}

The detail assessment was done through modification of model input parameters (Table 4.4) by establishing four physical settings with high percentage of coverage in the watershed. The impacts of specific land use/land cover, topography and soil type on runoff, soil loss and sediment yield were simulated. Four settings were considered and used in the simulation (Table 4.4). Four soil types were used because of the high coverage percentage in the area. Ferralic Cambisols and Humic Acrisols are the major soil types in the uplandland areas (Mfizigo juu) while Rhodic Ferralsols and Eutric Leptosols are found in lowland areas (Kibungochini) (Figure 4.10). Simulation of climate parameter inputs were used from two weather stations of Morning side and Mikula. 


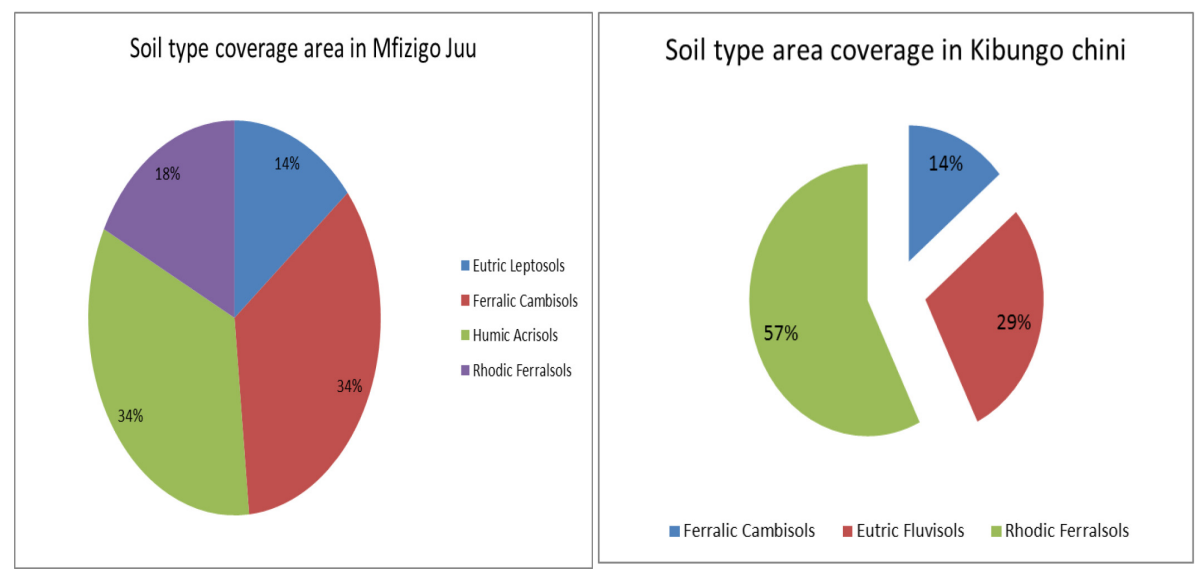

Figure 4.10. Soil coverage variation for Uplandland slope and lowland slope

Table 4.4. Modification of model input parameters for different settings/scenarios

\begin{tabular}{|l|l|l|}
\hline $\begin{array}{l}\text { Settings } \\
\text { scenarios \# }\end{array}$ & Location & Soil Type \\
\hline 1 & Upland slope & Ferralic Cambisols \\
\hline 2 & Upland slope & Humic Acrisols \\
\hline 3 & Lowland slope & Rhodic Ferralsols \\
\hline 4 & Lowland slope & Eutric Leptosols \\
\hline
\end{tabular}

\subsection{Experimental procedures}

Field measurements for water quality are important to determine whether significant changes occurred with time. The quality of data depends on sampling

\footnotetext{
${ }^{1}$ Upland slope + Ferralic Cambisols

${ }^{2}$ Upland slope + Humic Acrisols

${ }^{3}$ Lowland slope + Rhodic Ferralsols

${ }^{4}$ Lowland slope + Eutric Leptosols
} 
protocols including methods, time interval, documentation and purpose of field measurements. The accurate measurement and calculation of suspended transport depend on the time and sampling procedures used. In Wami-Ruvu Basin, there is limited continuous sediment data of its catchments. The data available are event-based and most were taken during rainy season. For the case of this study, the field measurement was done for the purpose of getting snap shot of TSS in dry season in the area where secondary streams converges in most hill slopes. After taking samples in the upper Ruvu Catchment, results helped to find small area of interest for testing the WEPP model. Although the results are weekly basis, the data will assist in proposing sediment sampling locations for monitoring.

\subsubsection{Hydrological data}

Sediment sampling locations were set up in order to obtain insight into the spatial variability of Suspended Solids Concentration (SSC) in the river systems. Continuous/throughout the year accessibility to sampling locations was considered in line with assessment of the spatial variation in sediment response. The sampling points were selected as much as possible on bridges (Figure 4-8) along the roads that cover the study area allowing easy access to collect river water samples (with suspended sediment) and to carry out streamflow velocity measurements. Seven sampling sites of Ruvu at Kibungo, Mgeta at Duthumi, Mgeta at Mgeta, Mfizigo at Lanzi, Mfizigo at Kibangile, Mvuha at Tulo and Mvuha at Ngangama were selected along the upper Ruvu River and its major tributaries. 
At each station, flow velocity measurements were done by ADC current meter (wadding method) and Q-liner instrument as shown in Figures 4 through 7. Flow velocity measurements were normally taken at $60 \%$ of the water depth $(0.6 \mathrm{D})$ at regular intervals along the cross- section in order to establish a stage discharge rating curve. For suspended sediment loading analysis, water sampling at each station of the river was demarcated into 3-5 sections in which three or five samples for analysis of suspended solids were taken by using D-48 sediment sampler and D-74 integrating suspended handline sampler into labeled container for laboratory analysis.
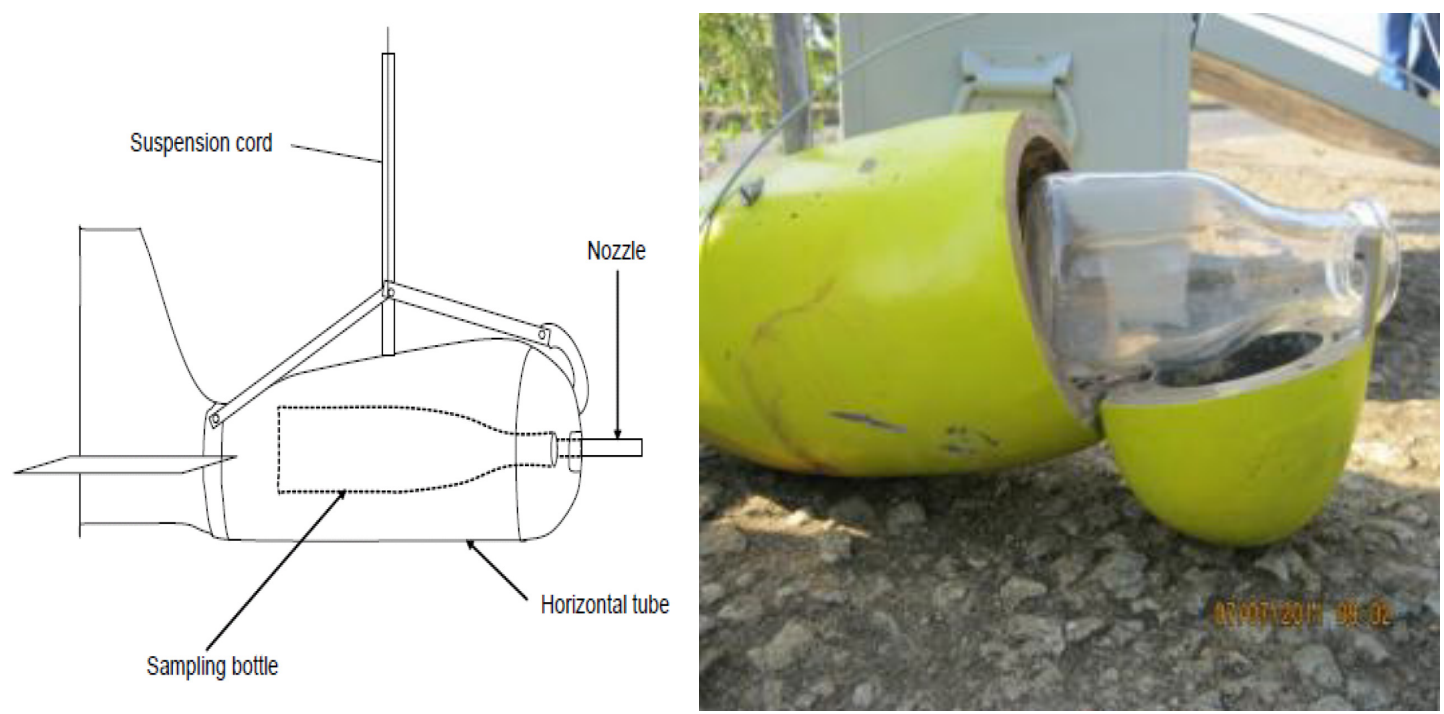

Figure 4.11. D-48 and D-74 sediment sampler used during field research 

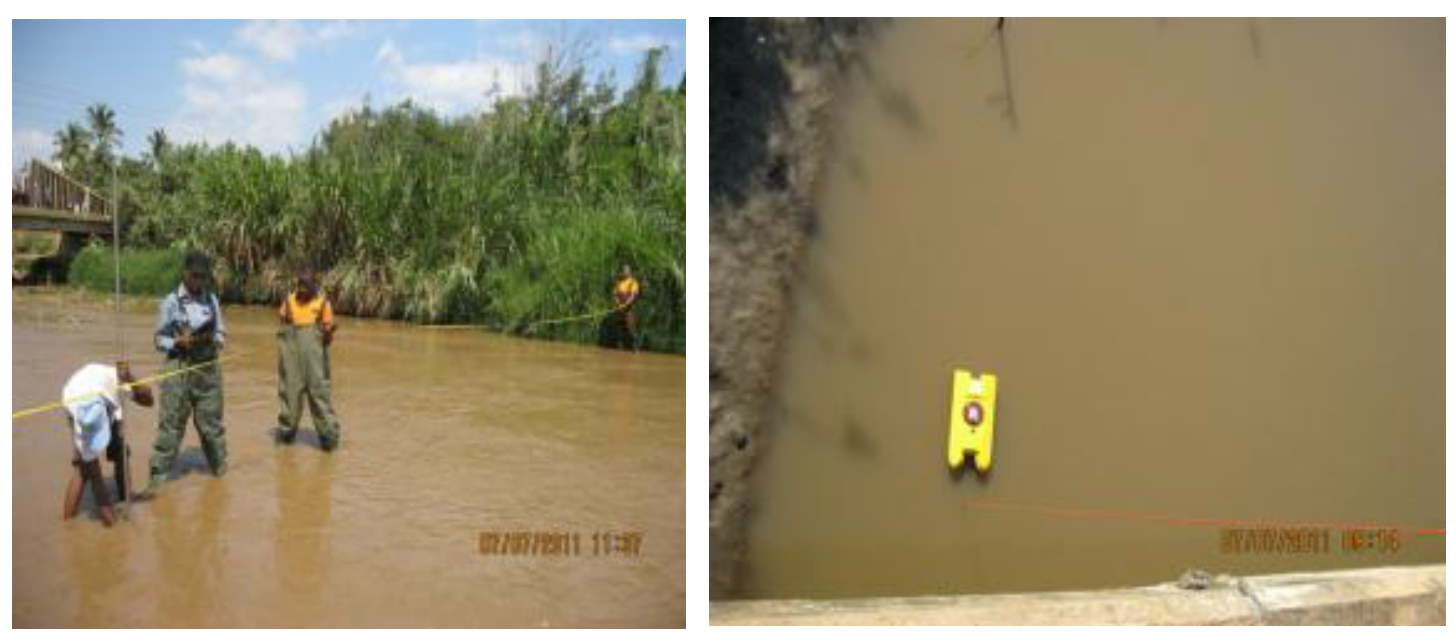

Figure 4.12. Field sampling photos and source of the diagram

\subsubsection{Suspended sediment load}

Analysis of suspended sediment load in water samples was carried at the Soil Laboratory of Sokoine University of Agriculture in Tanzania. Filtration of water samples for suspended solids was done by using vacuum pressure-pump fitted with glass fiber of $0.45 \mu \mathrm{m}$ diameter membrane filters. The membrane filters were initially dried in the oven at $70{ }^{0} \mathrm{C}$ for 24 hours and weighed (in grams) using a sensitive balance. The water samples were filtered, and then the wet filters were dried in an oven at $103{ }^{\circ} \mathrm{C}-105{ }^{0} \mathrm{C}$ for 1 hour. The weights in grams of the filters with dried residue were noted.

After the laboratory analysis, the amount of suspended solids in each sample was calculated using the formula;

$$
T=\frac{(A-B) * 1000}{C}
$$


Where; $\quad \mathrm{T} \quad$ Total suspended solids (mg/l)

A Weight of filter with dry residue in $(\mathrm{mg})$

B Dry weight of filter in (mg)

C Sample volume (ml)

Total suspended load (mg/s) was calculated by multiplying by river flow at crossing area in $\mathrm{m}^{3} / \mathrm{s}$ and then changed to $\mathrm{Kg} / \mathrm{s}$ by multiplying by 1000 . 


\subsection{RESULTS AND DISCUSSION}

This chapter summarizes the findings of the research in the form of results and it gives some discussions based on the analysis and interpretation being made. The results of this study are divided into two sub-divisions. The first part deals with the results obtained from the model. WEPP model average annual outputs for runoff, soil loss and sediment yield is presented and discussed. The second part is the result from direct field measurement. Spatial properties of the catchments erosion hotspots are identified from different soil types as affected by land use/land cover and topography and shown in figures. The model was simulated in four sub-watersheds delineated by the model; two in upland and two in the low land within the watershed. Also four scenarios were set to assess the effect of landuse/cover and soil type for high slope and low slope areas by assuming constant climate condition. GeoWEPP results of runoff, soil loss, sediment deposition from hillslopes and channels are displayed as text files and sediment yield is visualized as map showing hotspot areas by sub-watersheds that are very vulnerable to soil erosion (Renschler, 2003).

\subsection{Model Results}

\subsubsection{Average annual runoff}

\section{Effect of Topography and Land use/land cover}

Average annual runoff volume on cropland, open wood land and grassland is shown to be greatest in the most of all sub-watersheds as shown in Figures 5.3 through 5.6. In these areas, the surface has been paved or soil is no longer retaining water which 
leads to rainfall to be converted to runoff. The low runoff indicated in landuse/cover characterized by shrubs/bushland and natural forest. The model simulated high amount of runoff in Mfizigo Juu $\left(11,247 \mathrm{~m}^{3} / \mathrm{ha} / \mathrm{yr}\right)$ and Mvuha $\left(9,293 \mathrm{~m}^{3} / \mathrm{ha} / \mathrm{yr}\right)$ as it is caused by higher elevation and substantial land use/land cover contributing factors (Figure 5.1). Mfizigo Juu is characterized by $41 \%$ of woodland at Tegetero, Kibogwa and Kinole wards which makes runoff to be high as related to land use/land cover. Although there are patches of natural forest that can be found in Kibungo juu and Mkuyuni wards, but still high rainfall caused high runoff volume. Most of Mvuha sub-watershed has been converted to agriculture and grassland in larger area of Kasanga, Kolero and Mvuha wards. However, being in lower elevation makes the area to be flooding area of runoff volume from highland. Figure 5.1 shows Msumbizi and Kibungo chini sub-watersheds with low average annual runoff volume. Msumbizi area, which covers Tununguo and Kiroka wards, is more characterized by woodland (58\%) and natural forest (16\%), while Kibungo chini area is characterized by open woodland with cultivation (94\%). The average annual runoff volumes at Msumbizi and Kibungo chini are $5689 \mathrm{~m}^{3} / \mathrm{yr}$ and $4578 \mathrm{~m}^{3} / \mathrm{yr}$, respectively.

Moreover, runoff depth estimated under four scenarios shows some variations with land use/land cover both in highland steep slope and lowland slope areas. Results show cultivated land to have maximum average annual runoff depth of $1135 \mathrm{~mm}$. The minimum average runoff depth was $51 \mathrm{~mm}$ represented by bushland and natural forest areas. A summary of results of the average annual runoff depths for all scenarios as related to land use/land cover are shown in Figures 5.4 through 5.7. 


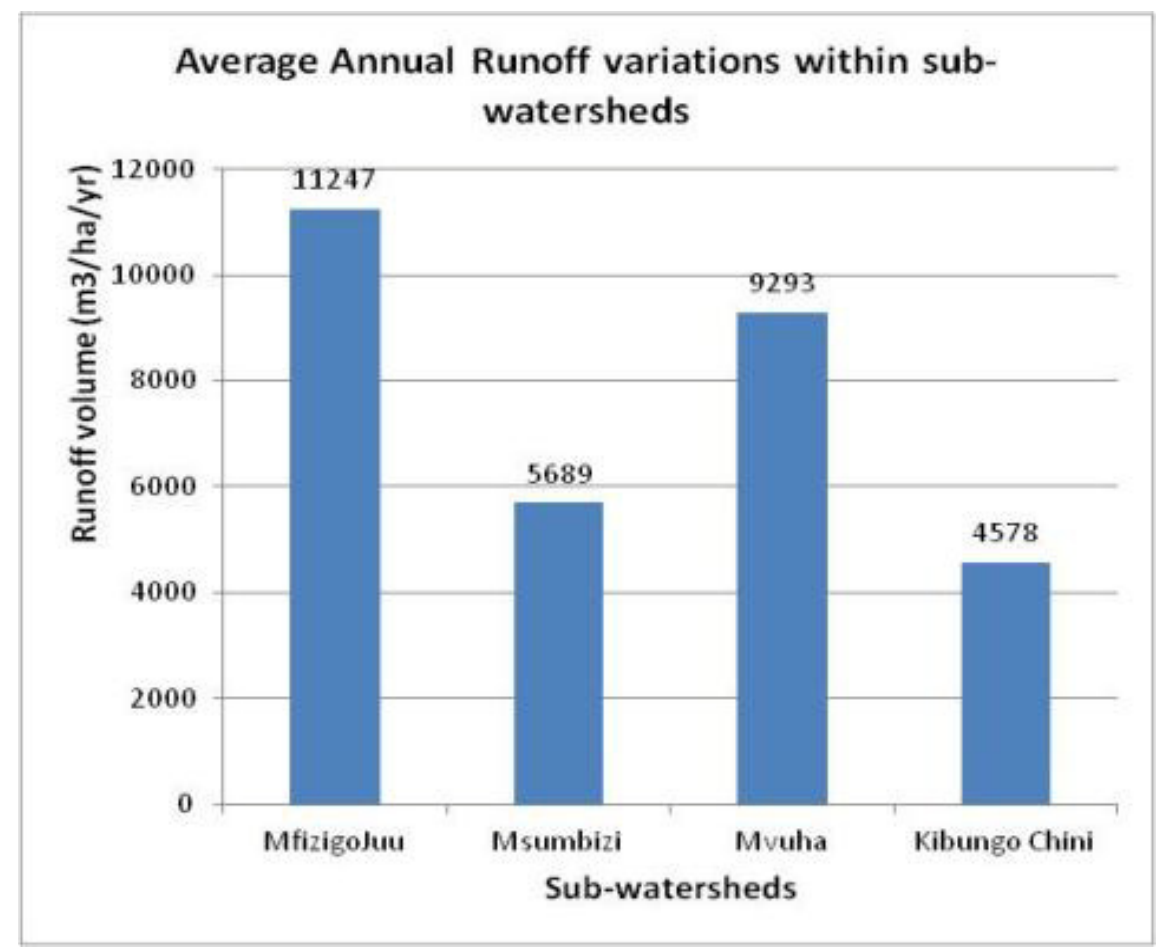

Figure 5.1. Average annual runoff variations within the sub-watersheds as estimated by the model

The average annual runoff volume as estimated by model showed good correlation with sub-watershed characteristics. It has indicated that the amount of runoff in Mfizigo and Mvuha is high caused by upland high slopes with open woodland land cover and some patches of agricultural land. Moreover, the runoff estimated at Kibungo chini showed gentle slope as shown in Table 5.1. Runoff of Msumbizi was low, although the sub-watershed is located at high slope but characterized by the natural forest landcover.

Discharge at the outlet of watershed depends on drainage area, inflow or outflow of groundwater to or from the surface area. The high discharge at Kibungo chini subwatershed in Figure 5.2 shows high discharge volume of $3462 \mathrm{~m}^{3} / \mathrm{s}$ compared to other 
sub-watersheds because it is located at the outlet point. However, predicted results could be contributed by other factors of topography, soil types, size of the drainage forming area.

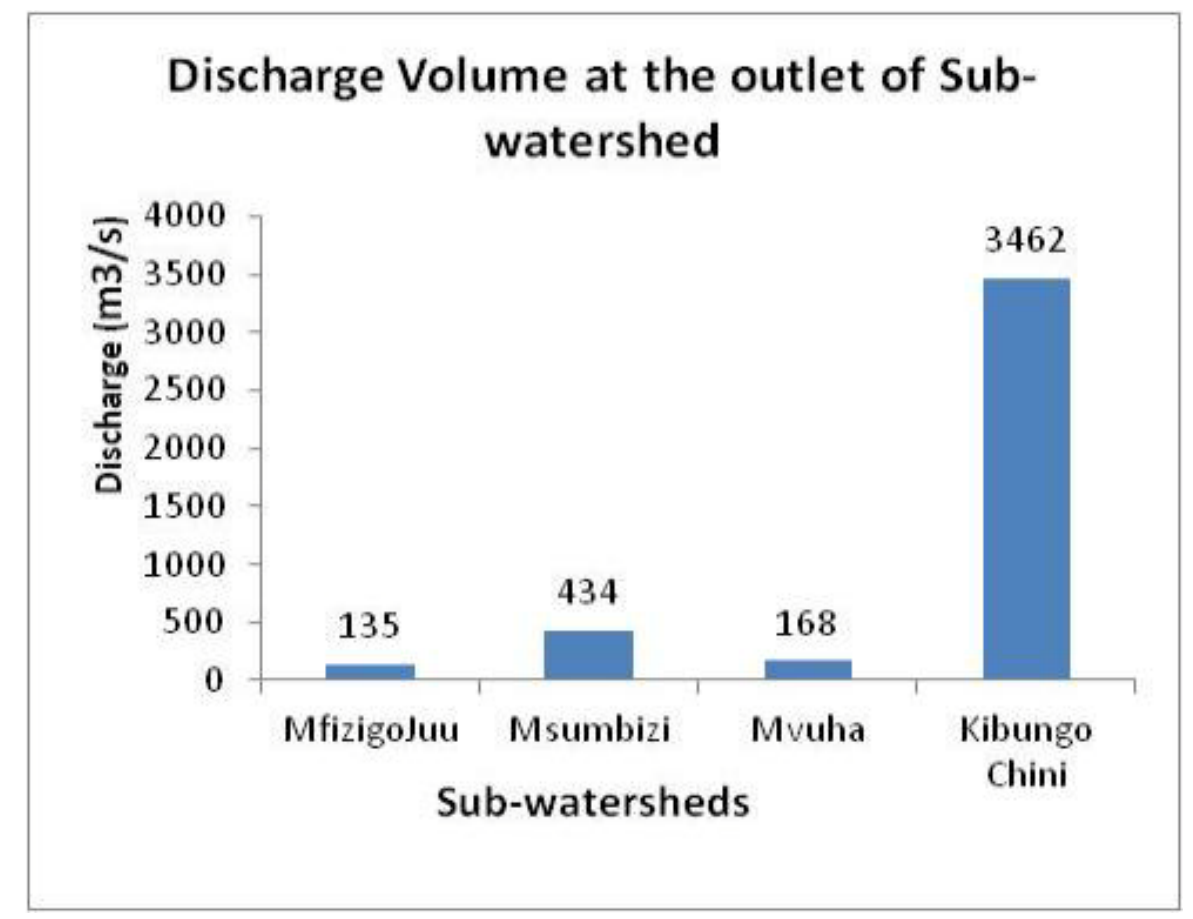

Figure 5.2. Average discharge volume variations within the sub-watersheds as estimated by model

\subsubsection{Soil Loss}

\section{Effect of Land use/land cover}

Soil loss seems to be affected by land use/land cover, runoff and topography in all subwatersheds. The areas with high slopes tend to increase soil loss in different land use/land cover. WEPP model watershed simulation predicated minimum average soil loss rate in 
grassland and natural forest areas. The minimum annual soil loss ranged from $0.33 \mathrm{~kg} / \mathrm{m}^{2}$ to $9.14 \mathrm{~kg} / \mathrm{m}^{2}$. The reason for these estimates was the coverage area in watershed for the cultivated land land use/land cover to be small compared to woodland and natural forest (Figure 5.3).

\section{Kibungo Landuse/land cover}

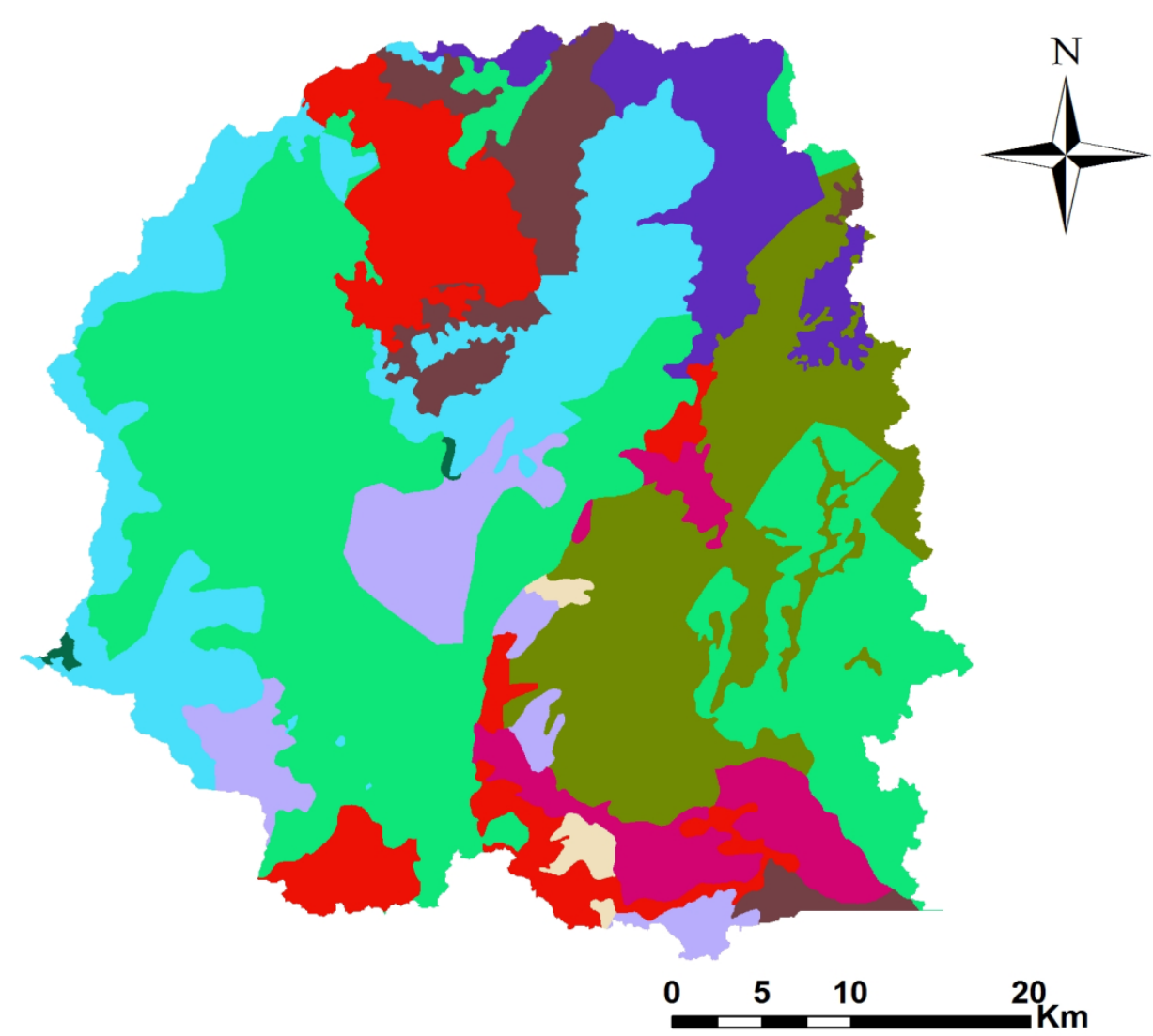

Landuse/land cover

Wooded Grassland

Open Woodland

Closed Woodland

Open Grassland

Woodland with Scattered Cropland

Natural Forest

Grassland with Scattered Cropland

Bushland with Scattered Cropland

Cultivation with Herbaceous Crops Mixed Cropland 
Figure 5.3. Land use/land cover in Kibungo watershed as delineated by WEPP model

The maximum average annual soil loss was in woodland and cultivated land as compared to natural forest/bushland with minimum average soil loss $0.5 \mathrm{~kg} / \mathrm{m}^{2}$ in steep slope and $0.1 \mathrm{~kg} / \mathrm{m}^{2}$ in lowland areas (Table 5.1). However, although soil in woodland is covered but the area is disturbed land cover with severity fire every year makes bottom land to be bare and reduce its erosivity and increase erodibility by water.

Table 5.1. Summary of variation in soil loss and sediment yield with land use/land cover under different scenarios

\begin{tabular}{|c|c|c|c|c|c|c|c|c|}
\hline \multirow[b]{2}{*}{ Landuse } & \multicolumn{2}{|l|}{ Scenario 1} & \multicolumn{2}{|c|}{ Scenario 2} & \multicolumn{2}{|c|}{ Scenario 3} & \multicolumn{2}{|c|}{ Scenario 4} \\
\hline & $\begin{array}{l}\text { Soil Loss } \\
\left(\mathrm{kg} / \mathrm{m}^{2}\right)\end{array}$ & $\begin{array}{l}\text { Yield } \\
(\mathrm{t} / \mathrm{ha})\end{array}$ & $\begin{array}{l}\text { Soil } \\
\text { Loss } \\
\left(\mathrm{kg} / \mathbf{m}^{2}\right)\end{array}$ & $\begin{array}{l}\text { Yield } \\
\text { (t/ha) }\end{array}$ & $\begin{array}{l}\text { Soil } \\
\text { Loss } \\
\left(\mathrm{kg} / \mathbf{m}^{2}\right)\end{array}$ & $\begin{array}{l}\text { Yield } \\
(\mathrm{t} / \mathrm{ha})\end{array}$ & $\begin{array}{l}\text { Soil } \\
\text { Loss } \\
\left(\mathbf{k g} / \mathbf{m}^{2}\right)\end{array}$ & $\begin{array}{l}\text { Yield } \\
\text { (t/ha) }\end{array}$ \\
\hline Bushland & 1.1 & 10.3 & 1.1 & 10.7 & 0.2 & 1.9 & 0.4 & 3.7 \\
\hline Cultivated land & 44.3 & 402.1 & 45.5 & 412.2 & 13.8 & 138.5 & 10.7 & 107.4 \\
\hline Grassland & 3.5 & 32.5 & 3.6 & 33.4 & 0.8 & 8.3 & 1.5 & 14.5 \\
\hline Natural forest & 0.5 & 5.3 & 0.6 & 5.5 & 0.1 & 1.0 & 0.2 & 2.0 \\
\hline Woodland & 4.8 & 43.5 & 4.8 & 43.3 & 1.1 & 11.4 & 1.7 & 16.9 \\
\hline
\end{tabular}

Moreover, Soil loss seems to be high in areas with high slopes (scenarios 1 and 2) and low in low slope areas (scenarios 3 and 4). The reason for this much difference is the effect of a runoff volume. Reduction of runoff depth from $1135 \mathrm{~mm}(1.135 \mathrm{~m})$ in scenarios 1 and 2 to $51 \mathrm{~mm}(0.051 \mathrm{~m})$ in scenarios 3 and 4 resulted a decrease in soil loss from $45.5 \mathrm{~kg} / \mathrm{m}^{2}$ to $10.7 \mathrm{~kg} / \mathrm{m}^{2}$ under cultivated land (Table 5.1 ).

Even though there is variations of soil loss, yield and runoff in all four scenarios, but landuse/land cover showed sensitivity in all factors considered in modeling. As 
summarized in Figure 5.8, cultivated land had high impact on erosion process which leads to high sediments deposition.

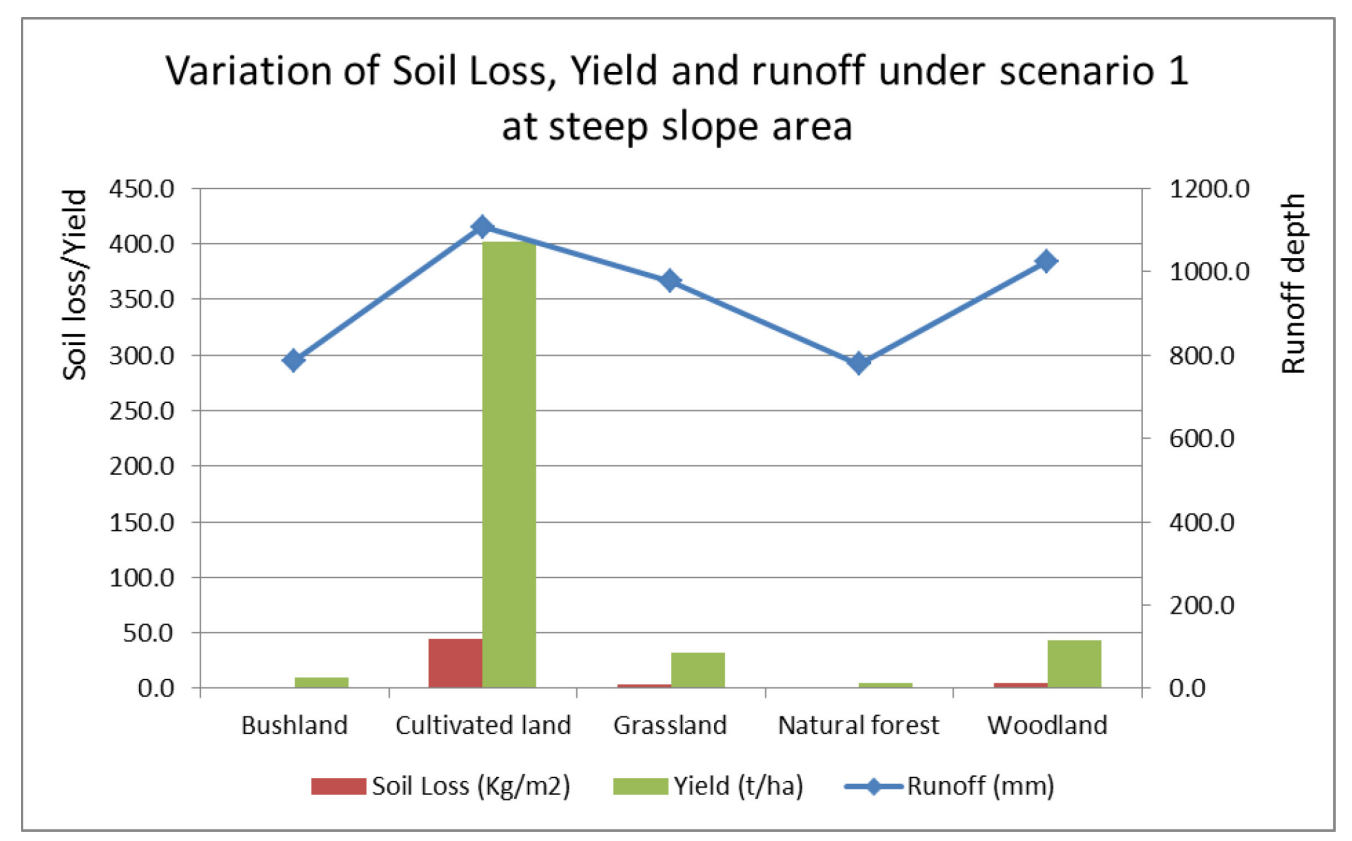

Figure 5.4. Variation of soil loss, yield and runoff with land use/land cover under scenario 1 in steep slope area as estimated by the model 


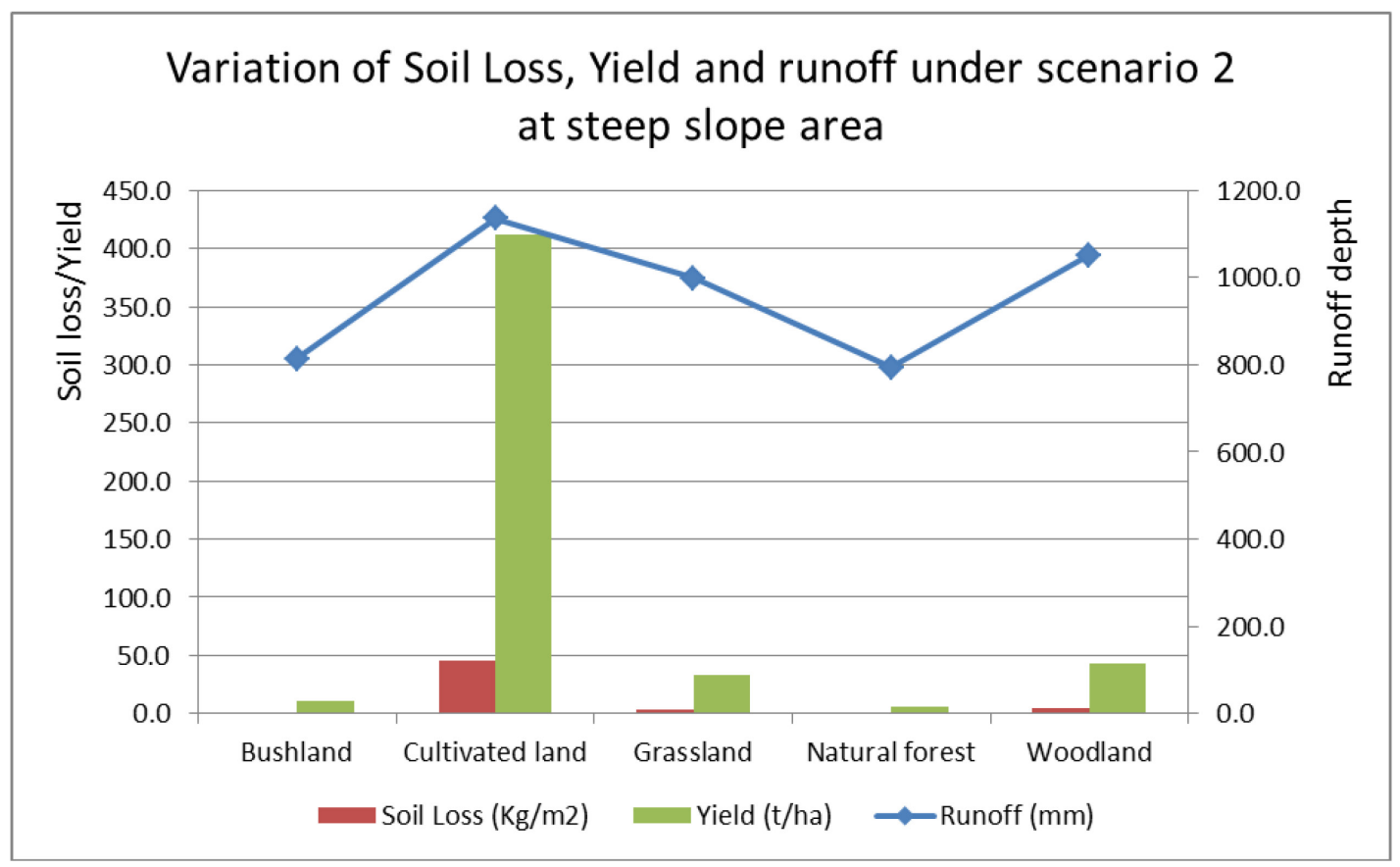

Figure 5.5. Variation of soil loss, yield and runoff with land use/land cover under scenario 2 in steep slope area as estimated by the model

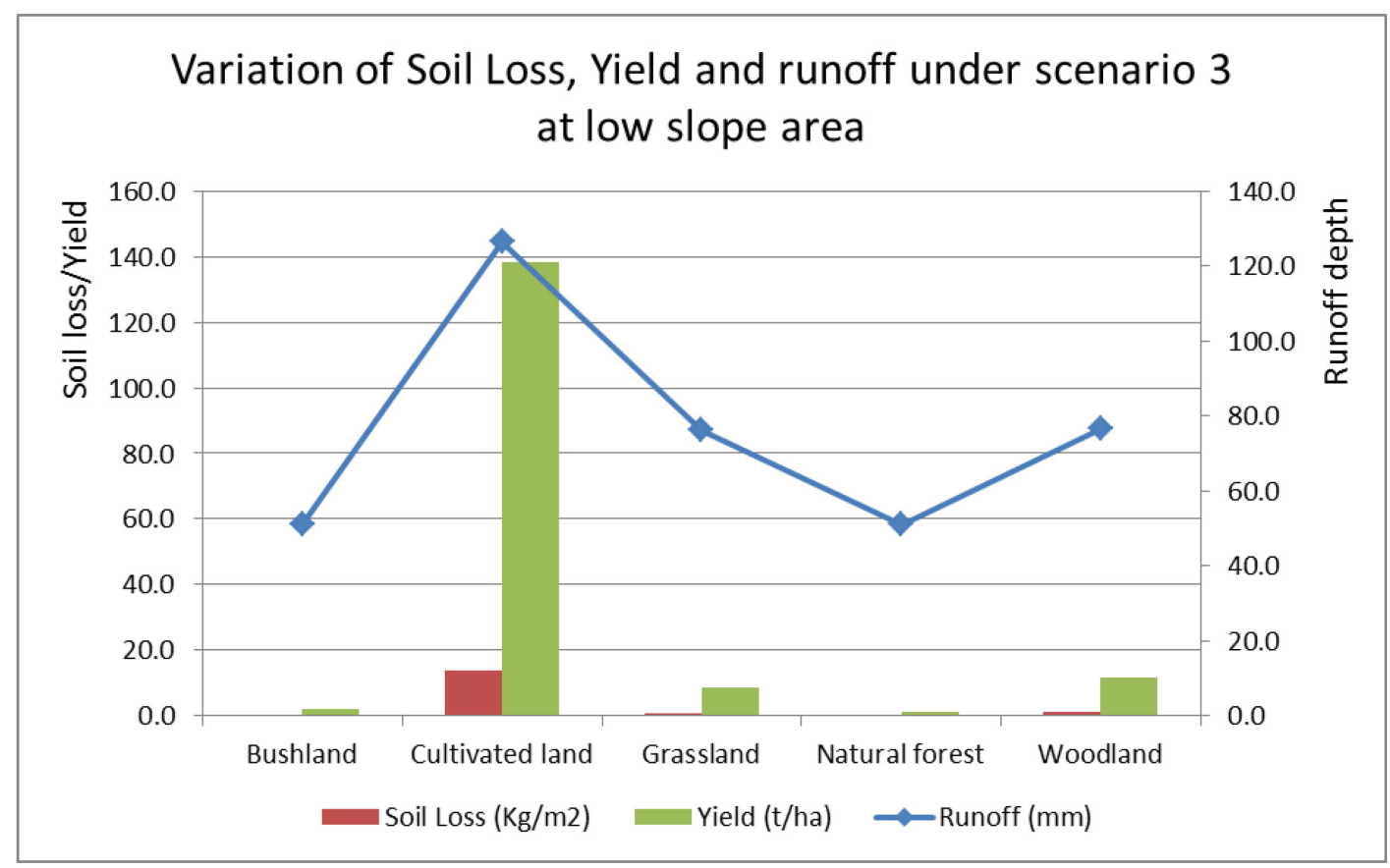

Figure 5.6. Variation of soil loss, yield and runoff with land use/land cover under scenario 3 in low slope area as estimated by the model 


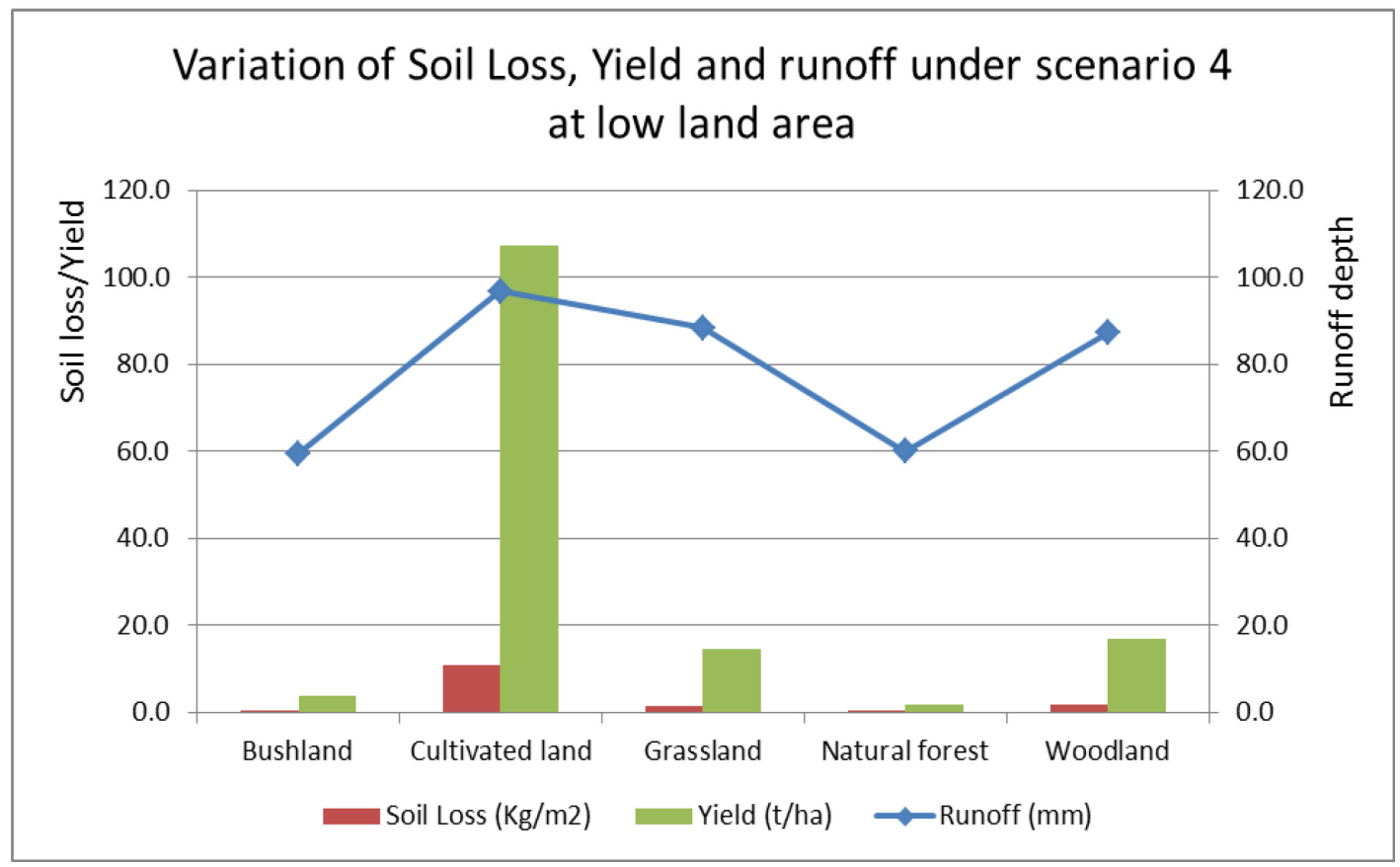

Figure 5.7. Variation of Soil Loss, Yield and Runoff with Land use/land cover under scenario 4 in low land area as estimated by model

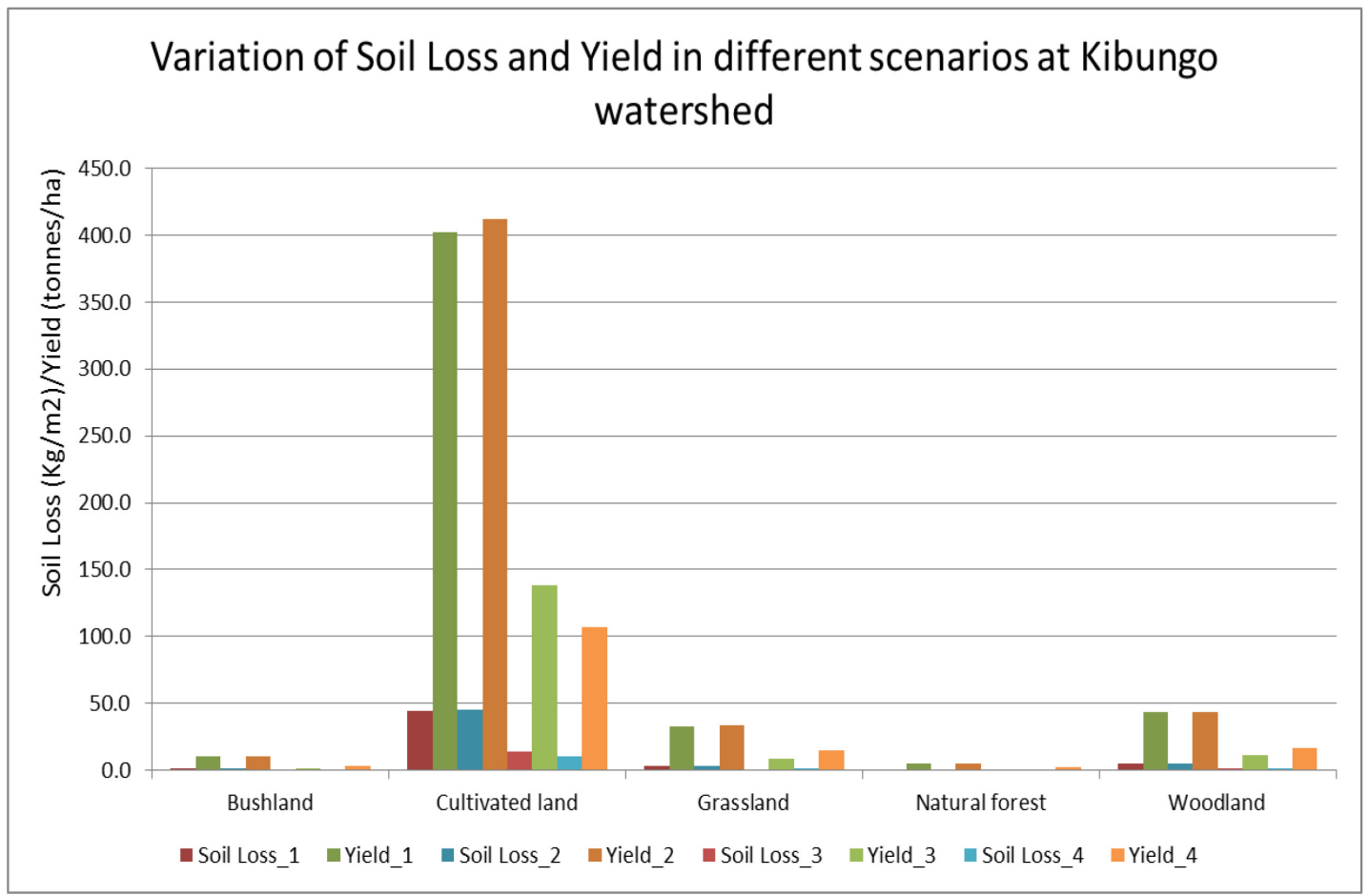

Figure 5.8. Variation of annual soil loss and yield with land cover at Kibungo watershed 


\section{Effect of Soil Type}

Major soil type of the Mfizigo Juu subwatershed is Humic Acrisols forming (34\%), Ferralic Cambisols (34\%) and Rhodic Ferrasols at (18\%). This type of soil showed high percentage of clay and organic matter which makes it easily to erode as indicated in Table 5.1. Ferralic Cambisols (41\%) and Humic Acrisols (32\%) which are mixture of sand-clay-loam in texture dominated in Mvuha sub-watershed. The results showed the eroded soil to contain high percent of silt ranging from $52.7 \%$ to $68.4 \%$ as indicated in Table 5.2. Simulated soil particles can be found in deposited soils loads or in river channels. The average annual total soil loss load in the Mfizigo Juu sub-watershed is 450.90 tonnes/ha/yr while the average annual simulated deposition rate is 2.75tonnes/ha/yr. Moreover, simulated results from Mvuha sub-watershed showed the annual average soil loss of 190.79 tonnes/ha/yr. Annual average soil deposition rate in this sub-watershed was 8.49tonnes/ha/yr. The major soil type at Msumbizi sub-watershed is Ferralic Cambisols (93\%) with sandy-clay texture but had less effect contribution as much as expected in soil loss and sediment yield. The annual total soil loss load in Msumbizi is 19.205 tonnes/ha/yr while the deposition rate is 1.09 tonnes/ha/yr.

WEPP simulation was also done in lower sub-watershed at Kibungo chini near Selembala ward area. The area has clay soil with eroded sediments of $30 \%$ and organic matter (50\%). Major soil type is Rhodic Ferralsols (57\%) and Eutric Fluvisols (29\%) that makes average annual soil loss to be 4.54 tonnes/ha/yr. The simulated annual deposition rate is 0.86 tonnes $/ \mathrm{ha} / \mathrm{yr}$. 
Table 5.2. Sediment Particle Information Leaving Channel at Kibungo watershed

\begin{tabular}{|r|r|r|r|r|r|r|}
\hline \multirow{2}{*}{ Class } & \multirow{2}{*}{$\begin{array}{c}\text { Diameter } \\
(\mathbf{m m})\end{array}$} & $\begin{array}{c}\text { Specific } \\
\text { Gravity } \\
(\mathbf{\%})\end{array}$ & $\begin{array}{c}\text { Sand } \\
\mathbf{( \% )}\end{array}$ & Silt (\%) & $\begin{array}{c}\text { Particle Composition Fraction } \\
\mathbf{( \% )}\end{array}$ & $\begin{array}{c}\text { O.M } \\
\mathbf{( \% )}\end{array}$ \\
\cline { 3 - 8 } & & 2.6 & 0 & 0 & 100 & 16.7 \\
\hline 1 & 0.002 & 2.65 & 0 & 100 & 0 & 0 \\
\hline 2 & 0.01 & 1.8 & 0 & 60 & 40 & 6.7 \\
\hline 3 & 0.04 & 1.6 & 48.4 & 35.2 & 16.5 & 2.7 \\
\hline 4 & 0.6 & 2.65 & 100 & 0 & 0 & 0 \\
\hline 5 & 0.2 & & & & & \\
\hline
\end{tabular}

The highest annual average soil loss was in Mfizigo Juu and Mvuha subwatersheds because of clay loamy soil characteristics with $0 \%$ of sand as indicated in Table 5.2. Estimated soil loss and sediment yield results from the model at different soil types seemed to be affected by Ferralic Cambisols (CMo) and Humic Acrisols(Acu) in steep slope areas of Mfizigo and Mvuha sub-watersheds. Also, results showed high impact of Eutric Leptosols (LPe) and Rhodic Ferrasols (FRr) in lowland areas of Msumbizi and Kibungo chini. Soil loss under scenario 1 and 2 in detail assessment which is steep slope area seems not to be affected much by changing type of soil as it affect runoff depth (Figure 5.9). However, Figure 5.10 shows the impact of soil type on both soil loss and runoff depth in low slope areas by comparing results in Rhodic Ferralsol (LPe) and Eutric Leptosols (FRr). According to simulated results with modification of inputs in different scenarios, soil type has impact for both soil loss and yield in areas with less management practices as shown in Figure 5.11 through Figure 5.13. In this case, cultivated land gives good results as compared to other land use/land cover categories.

According to Cochrane and Flanagan (1999), there is great variability in predicting sediment loss from the watersheds as result of not simulating erosion in 
channels. The presence of differences observed in deposition rate and soil load could be caused by different types of soils in hillslopes and channels that makes channel to be erodible or acts as sediments trap. Clay soils are rich in nutrients and minerals; they are comprised of tiny particles that cause problems with drainage and aeration. Clay soils are easily compacted and cracks during dry season, and this makes the soil to be loose. Organic matter in eroded sediments reflects the ability of stabilized soil to resist erosion caused by water. In the flowing water, larger particles are deposited as velocity drop. The highest deposition rate was observed in Mvuha sub-watershed while lower rate was in Kibungo chini. This can be contributed by different factors including falling velocity and specific gravity of sediments at point of detachment. The soils in these sub-watersheds belong to classes 1 and 2 which have high specific gravity 2.6 and 2.65.

Table 5.3. Distribution of Primary Particles and Organic Matter in Kibungo watershed eroded Sediment

\begin{tabular}{|l|r|r|r|r|}
\hline \multirow{2}{*}{ Type } & \multicolumn{4}{|c|}{ Fraction } \\
\cline { 2 - 5 } & \multicolumn{1}{|c|}{ Mfizigo Juu } & \multicolumn{1}{c|}{ Msumbizi } & \multicolumn{1}{c|}{ Mvuha } & \multicolumn{1}{c|}{ Kibungo Chini } \\
\hline Clay & 0.397 & 0.46 & 0.377 & 0.307 \\
\hline Silt & 0.603 & 0.527 & 0.623 & 0.684 \\
\hline Sand & 0 & 0.013 & 0 & 0.009 \\
\hline $\begin{array}{l}\text { Organic } \\
\text { Matter }\end{array}$ & 0.066 & 0.077 & 0.063 & 0.051 \\
\hline
\end{tabular}




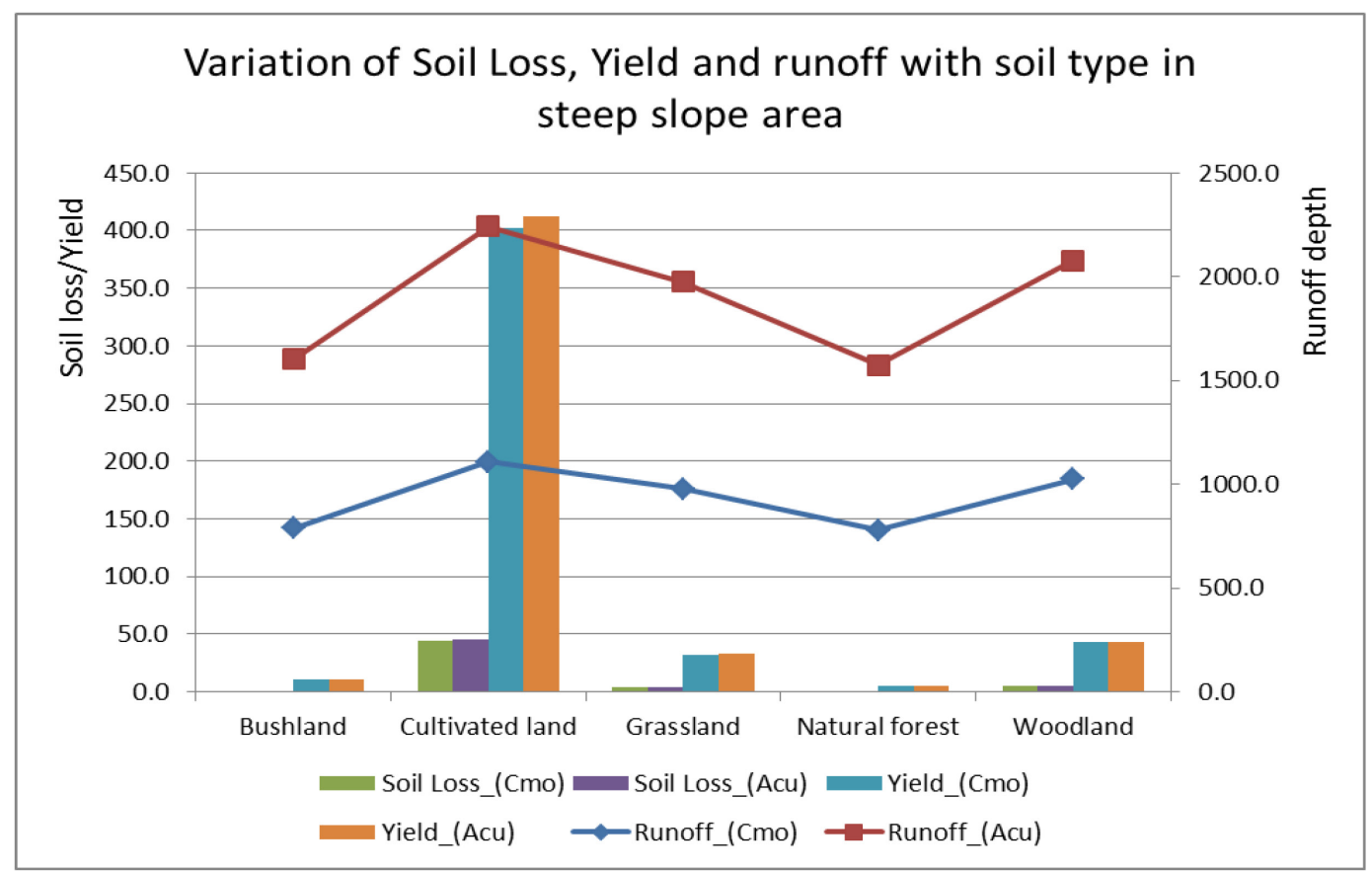

Figure 5.9. Variation of Soil Loss, Yield and Runoff with Soil type in steep slope areas as estimated by model

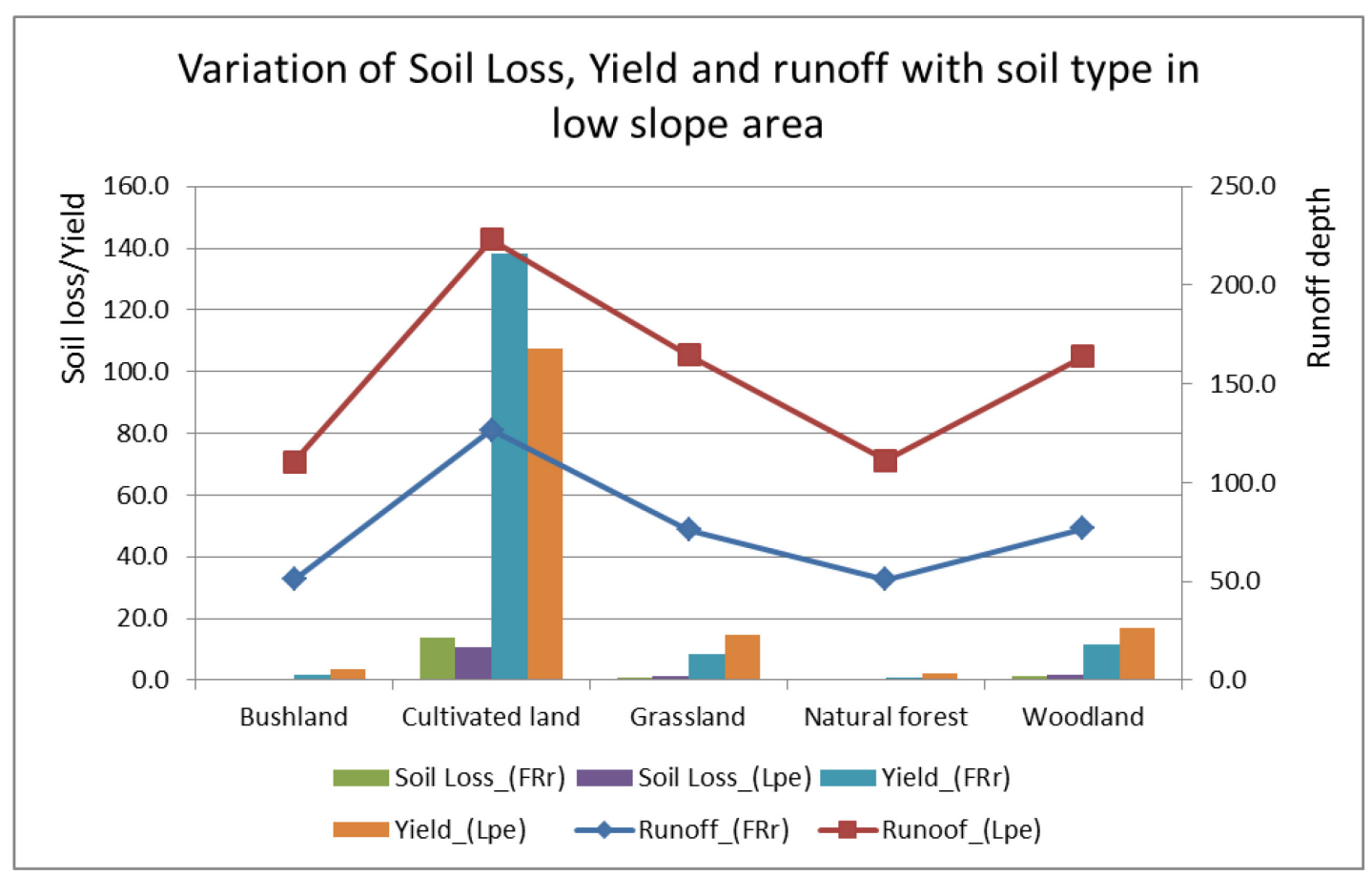

Figure 5.10. Variation of Soil Loss, Yield and Runoff with Soil type in low slope areas as estimated by model 


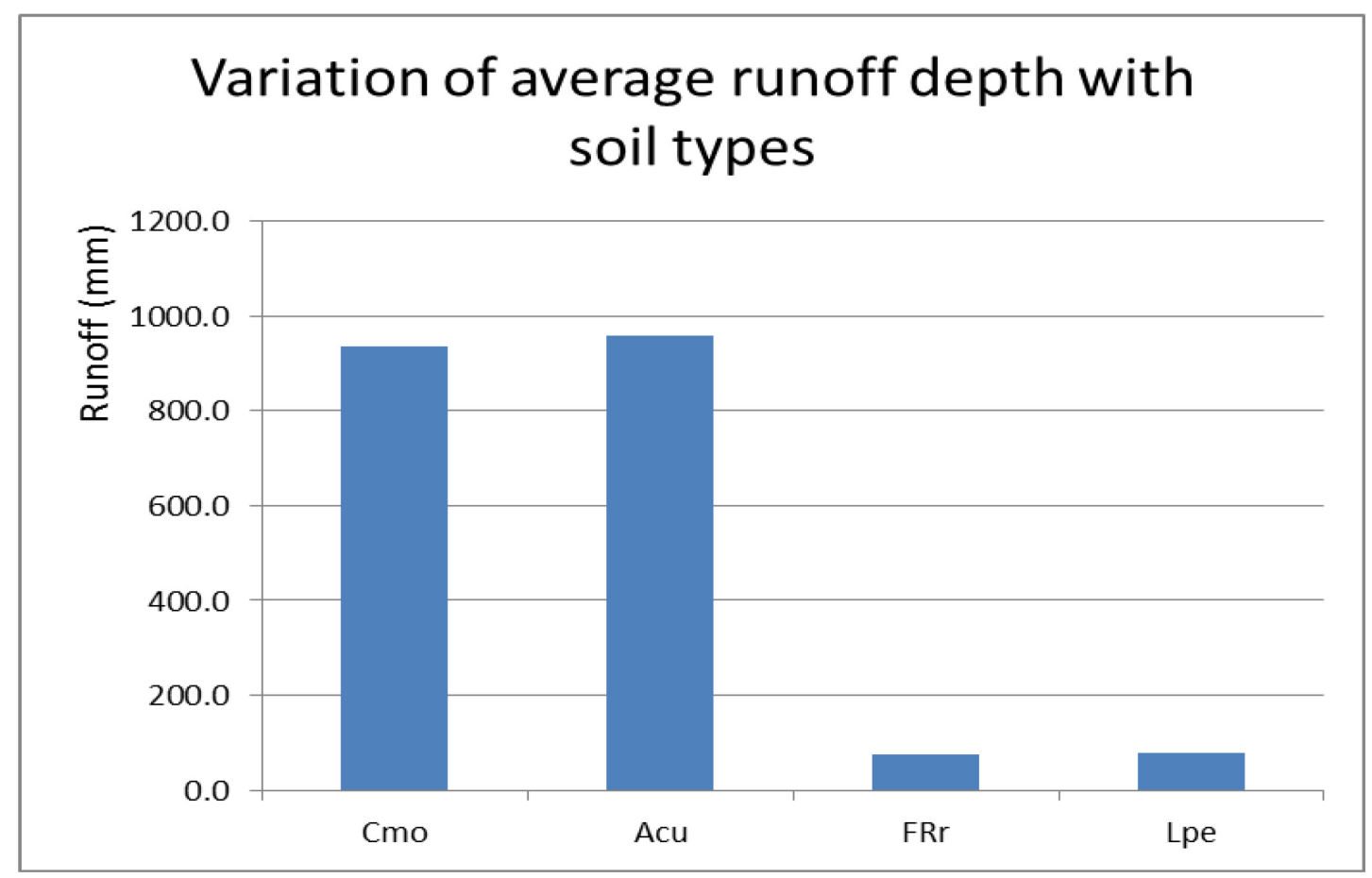

Figure 5.11. Variation of Runoff with Soil type as estimated by model

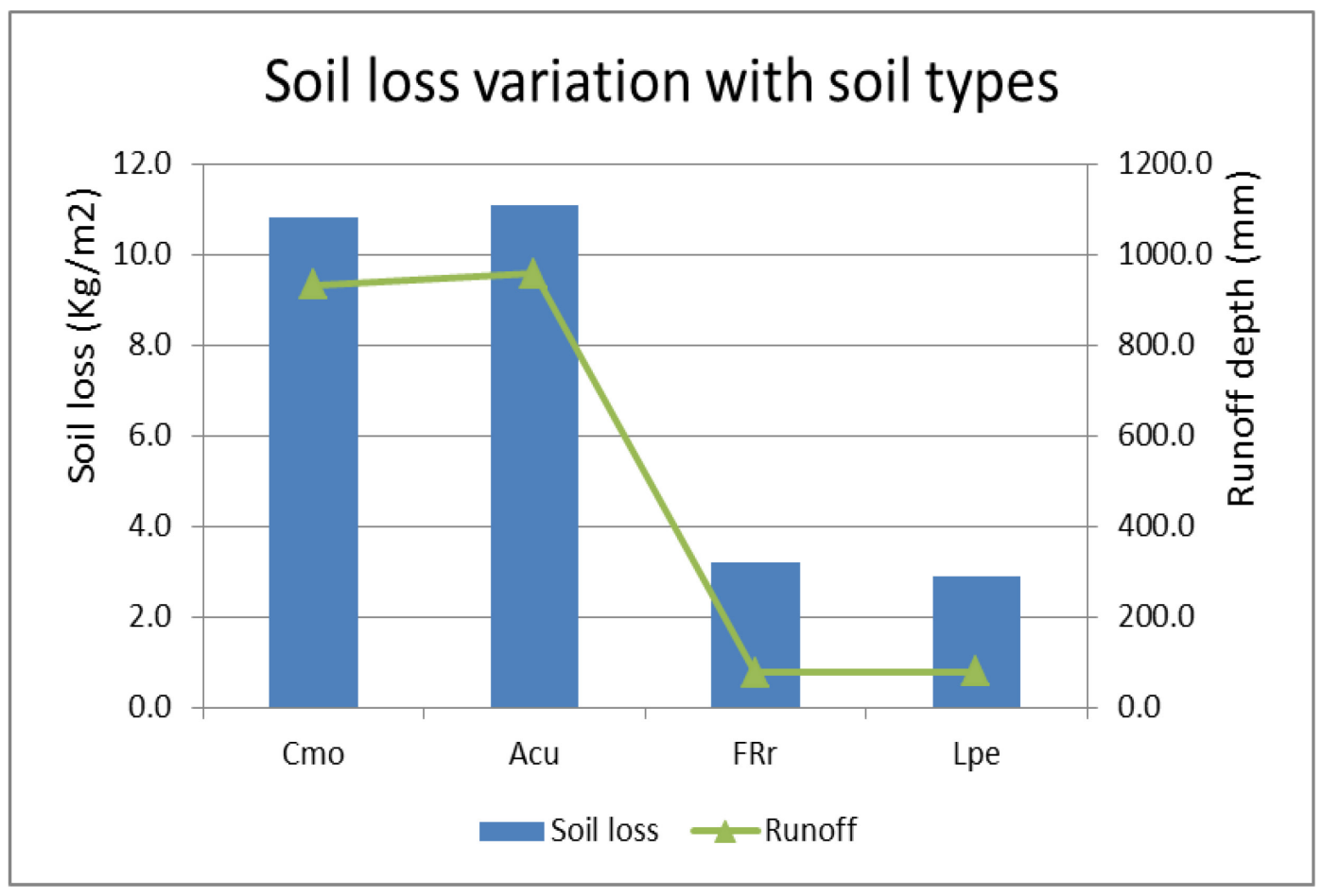

Figure 5.12. Variation of Soil Loss with Soil type as estimated by model 


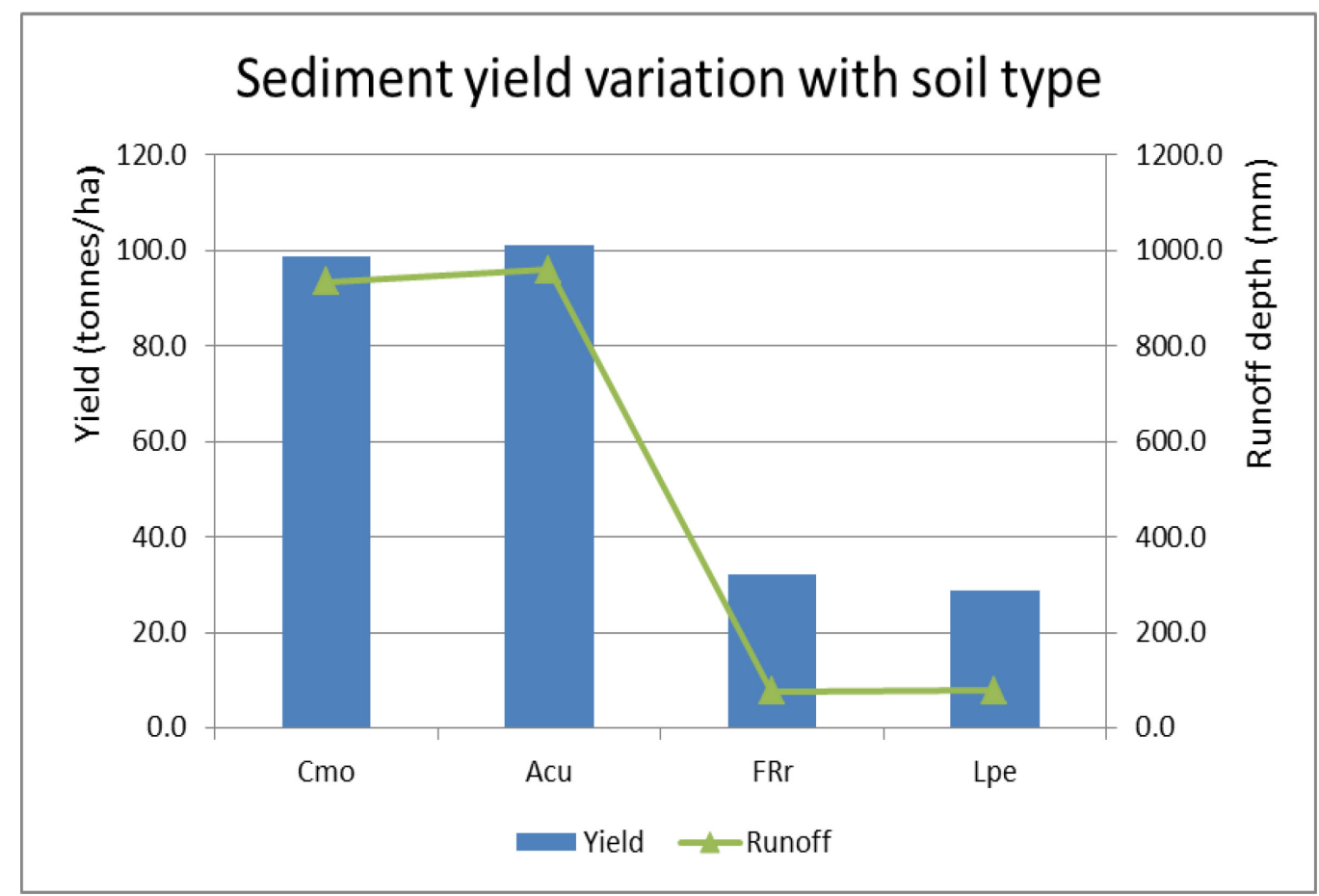

Figure 5.13. Variation of Soil Loss with Soil type as estimated by model

\subsubsection{Sediment yield}

GeoWEPP model generated sediment yield map which indicates the area with tolerable yield (i.e, from light to dark green) and not tolerable yield (i.e, from light to dark red). Results given from the model simulation are in a Tolerable maximum value (TValue) of 1tonne/ha/yr. Results were converted to 12 tonnes/ha/yr, the East Africa highlands soil loss rate tolerable limit as reported from previous studies (Kimaro et al., 2008 ) in order to get clear visualization of maps. Sediment yield was categorized in eight groups; four displayed in green color are below the tolerable soil losses. The other four categories are displayed in red color and are above the tolerable value which indicates areas with high level of yield as shown in (Figures 5.12 through 5.15). Since sediment 
yield is a function of contributing factors including topography, land use/land cover, runoff and land management practices, and the simulated results in four sub-watersheds prove good relation with regard to these factors.

The simulated average annual sediment yield at the Mfizigo Juu watershed outlet was $113,009,137.60$ tonnes/yr and sediment delivery ratio for the watershed was 0.30 . The contributing area was 81,113.82ha which includes 1023 hillslopoes and 411channels. Average annual sediment yield from Msimbizi sub-watershed was 183,430.00tonnes/yr and the predicted sediment delivery ratio for the watershed was 0.2 . Simulation created 272 hillslopes and 109 channels in 21,217.66 ha of contributing area. Mvuha and Kibungo chini are sub-watersheds at the downstream of Kibungo watershed. These areas showed 418,459,188tonnes/yr and 270,658.9tonnes/yr, respectively. Results showed 461 hillslopes and 185 channel in Mvuha, and also 78 hillslopes and 31 channels in Kibungo Chini. Sediment delivery ratio in Mvuha was 0.66 from 36,871.54ha contributing area while computed delivery ratio in Kibungo chini was 0.87 with a contributing area of 5,478ha. As shown in Figures 5.14 through 5.17, higher masses of soil losses from high rainfall and high elevation are expected in the zones with red color whereby the minimum losses are in the zone with green color. 


\section{Mfizigo Sediment Yield Map}

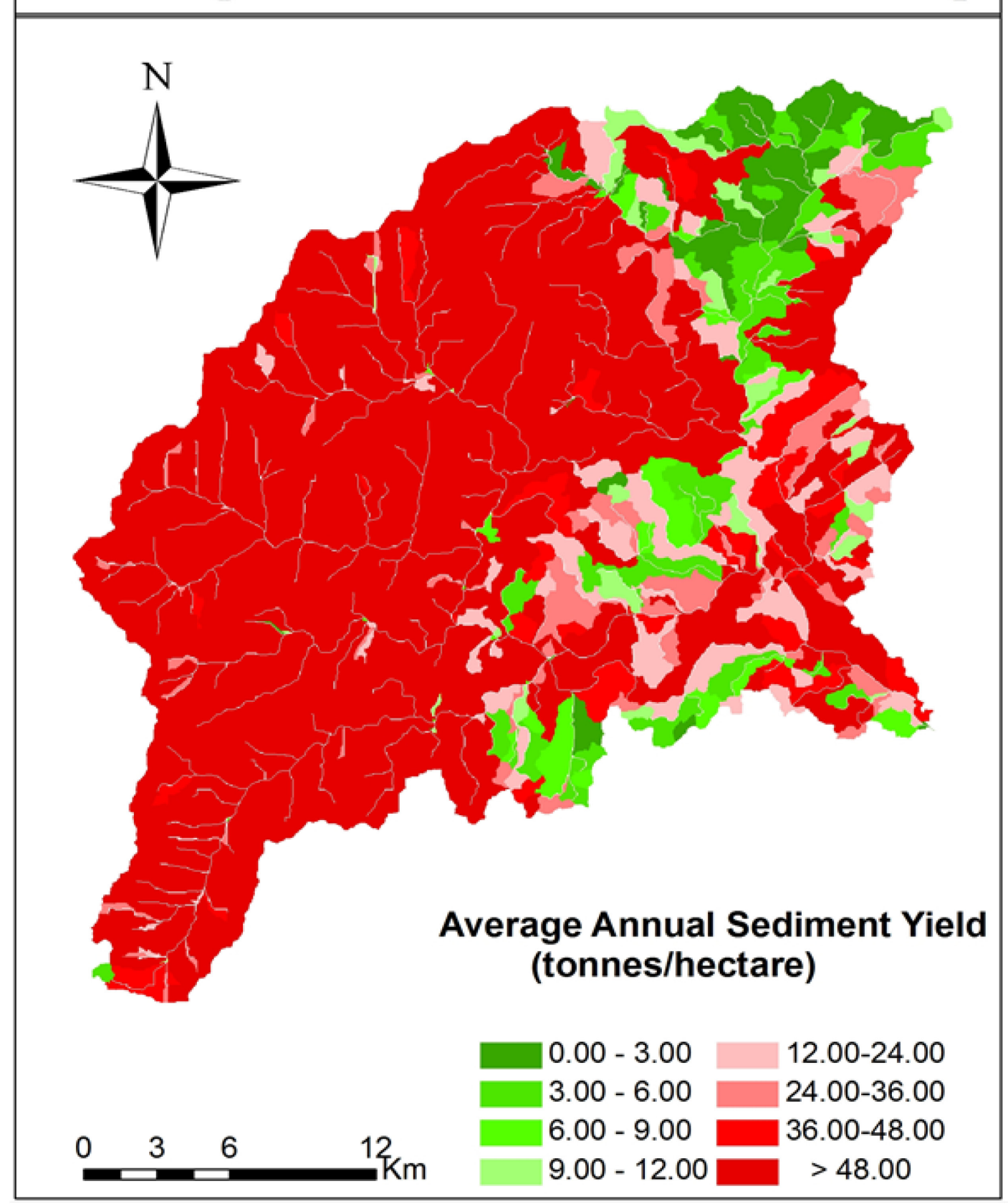

Figure 5.14. Map of average annual sediment yield for Mfizigo sub-watershed. 


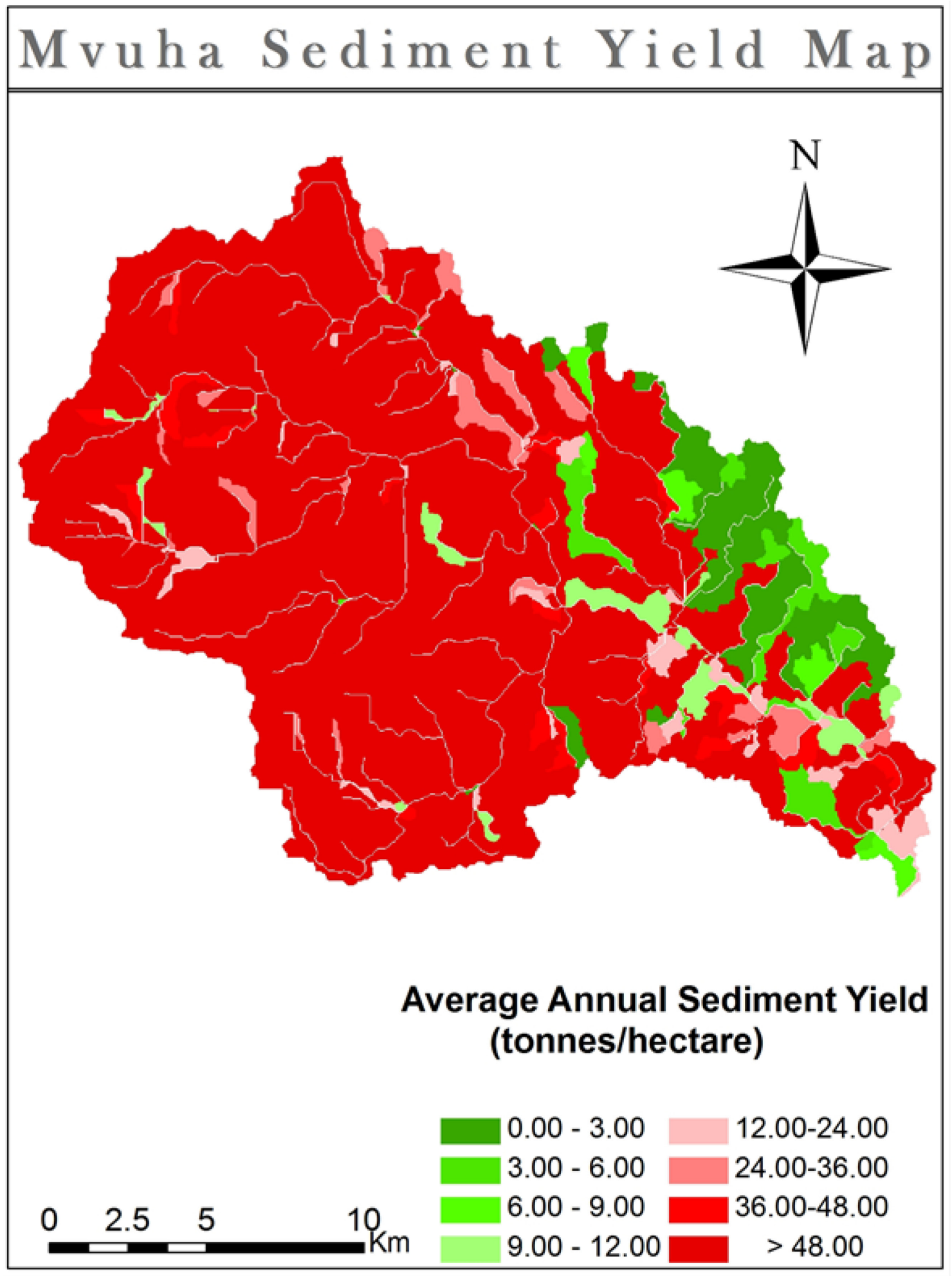

Figure 5.15. Map of average annual sediment yield for Mvuha sub-watershed. 


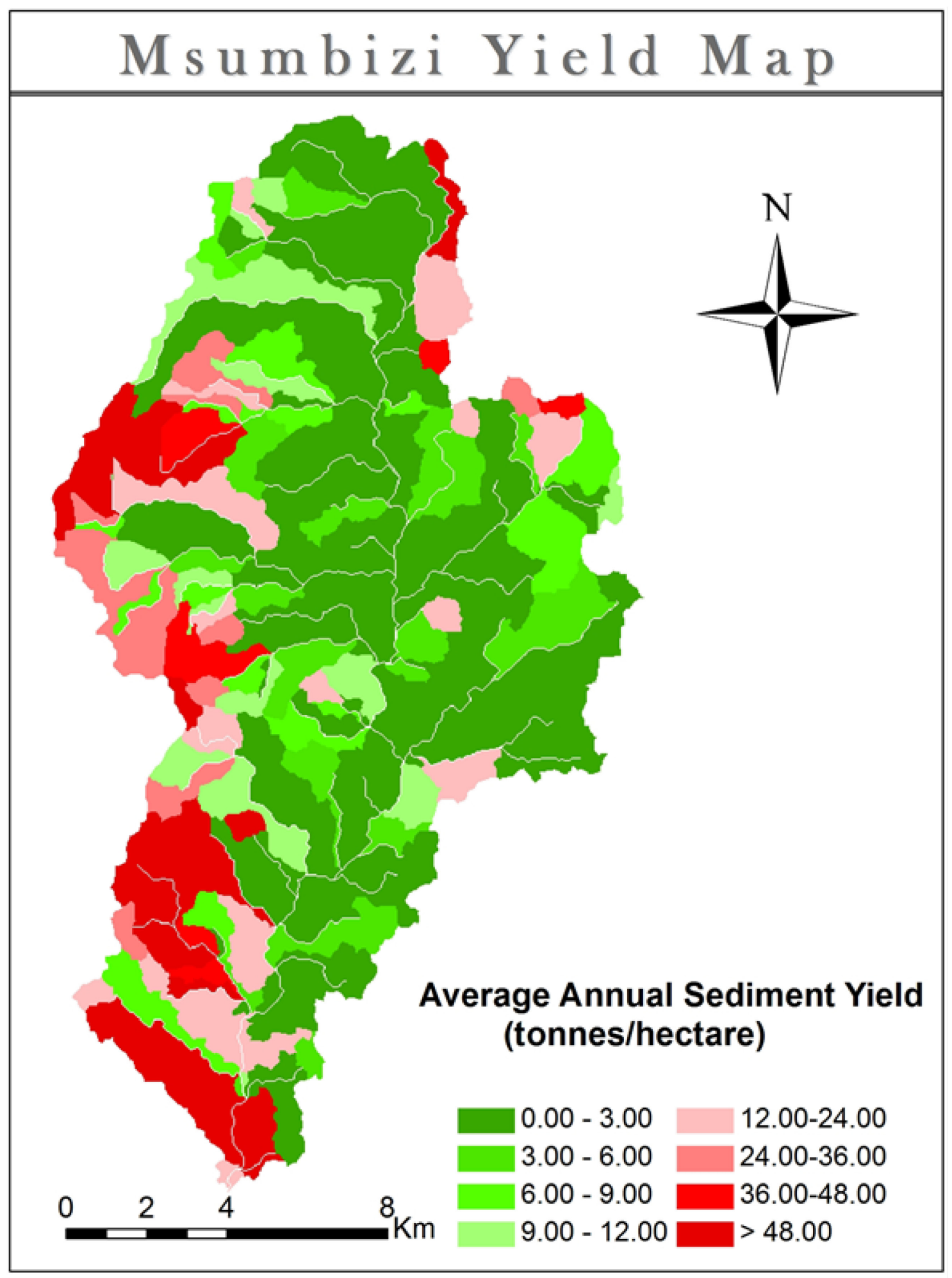

Figure 5.16. Map of average annual sediment yield for Msumbizi sub-watershed. 


\section{Kibungo chini Sediment Yield Map}

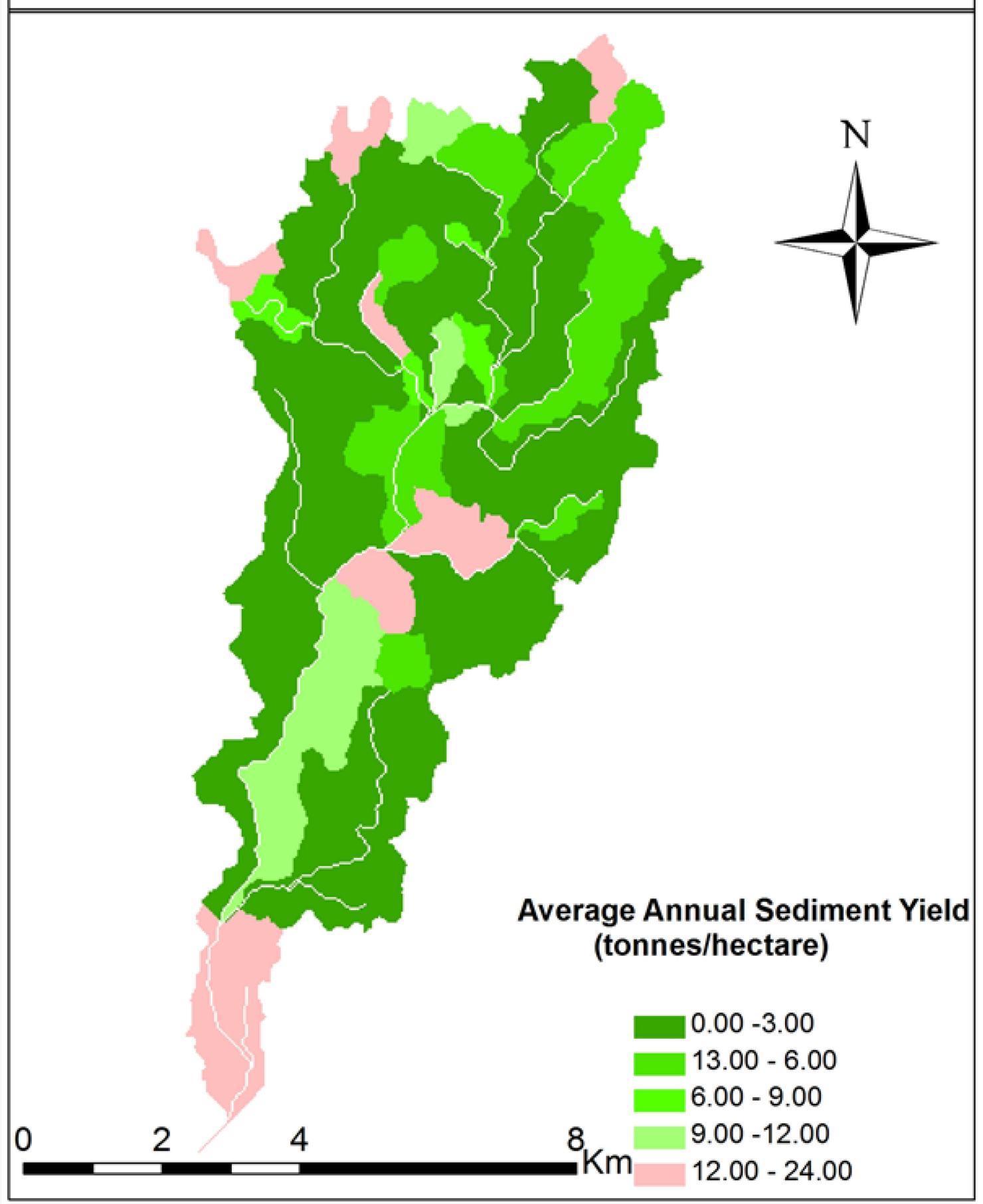

Figure 5.17. Map of average annual sediment yield for Kibungo Chini sub-watershed. 


\subsection{Field Results}

\subsubsection{Total Suspended Solids and Average Annual runoff}

During the field data collection campaign, the sediment load was observed to be higher at Mgeta at Duthumi (MD), Mvuha at Ngangama (MN) and Mvuha at Tulo (MT) as indicated in Figures 5-7. The levels observed at MD, MN and MT were $298.7 \mathrm{~kg} / \mathrm{s}$, $243.0 \mathrm{~kg} / \mathrm{s}$ and $351.8 \mathrm{~kg} / \mathrm{s}$, respectively. All these sampling locations are downstream of cultivated lands. MD in Mgeta River is located downstream of Mgeta, Singisa, Bwakila Juu, Bwakila Chini, Kolero and Kisaki wards. $\mathrm{MN}$ is located downstream of hillslope cultivated lands of Mtombozi, Kisemu, Kasnga and Mvuha wards. The MT is the location further downstream of $\mathrm{MN}$ at the same Mvuha River. $\mathrm{MM}$ is the starting location of Mgeta River at the mountain, which is not much degraded. Water can be clearly seen with less sediment.
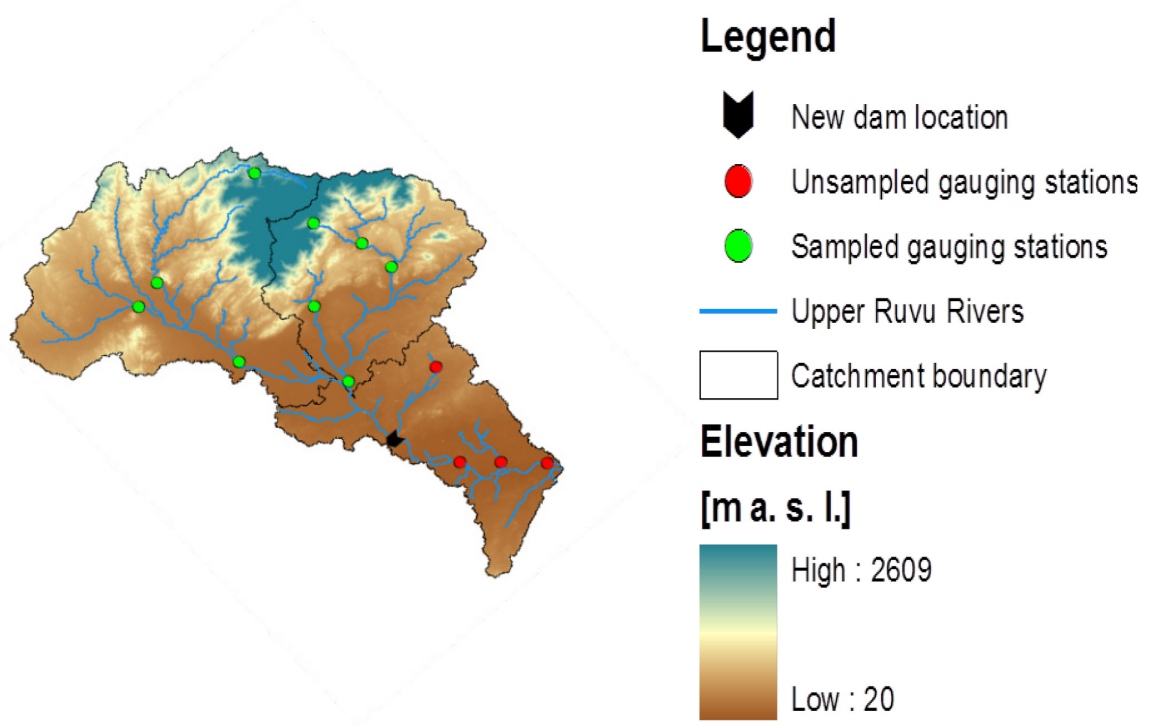

Figure 5.18. Selected spatial sediment sampling locations at upper Ruvu catchment 


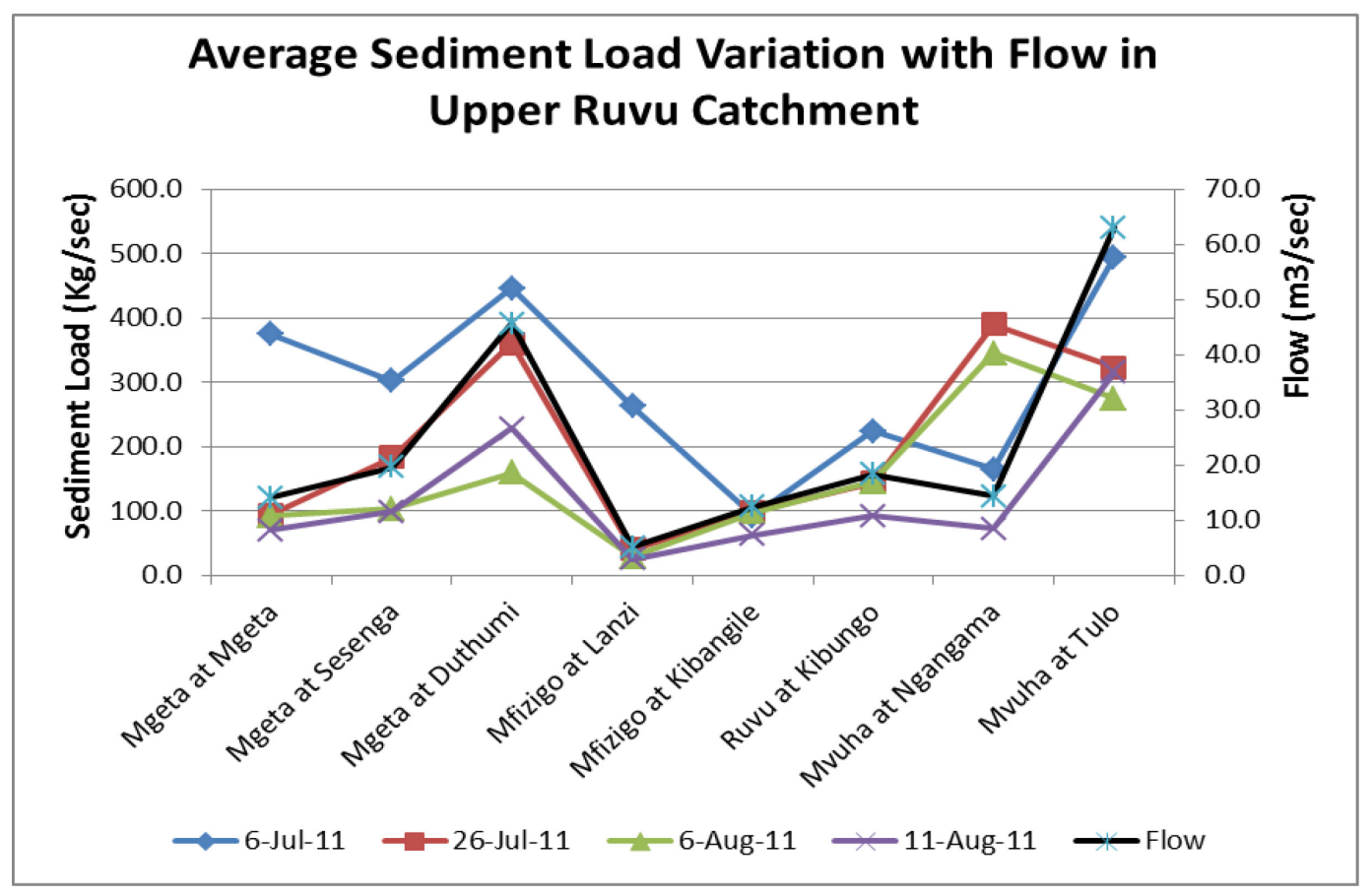

Figure 5.19. Sediments load and flows in the upper Ruvu catchment Rivers

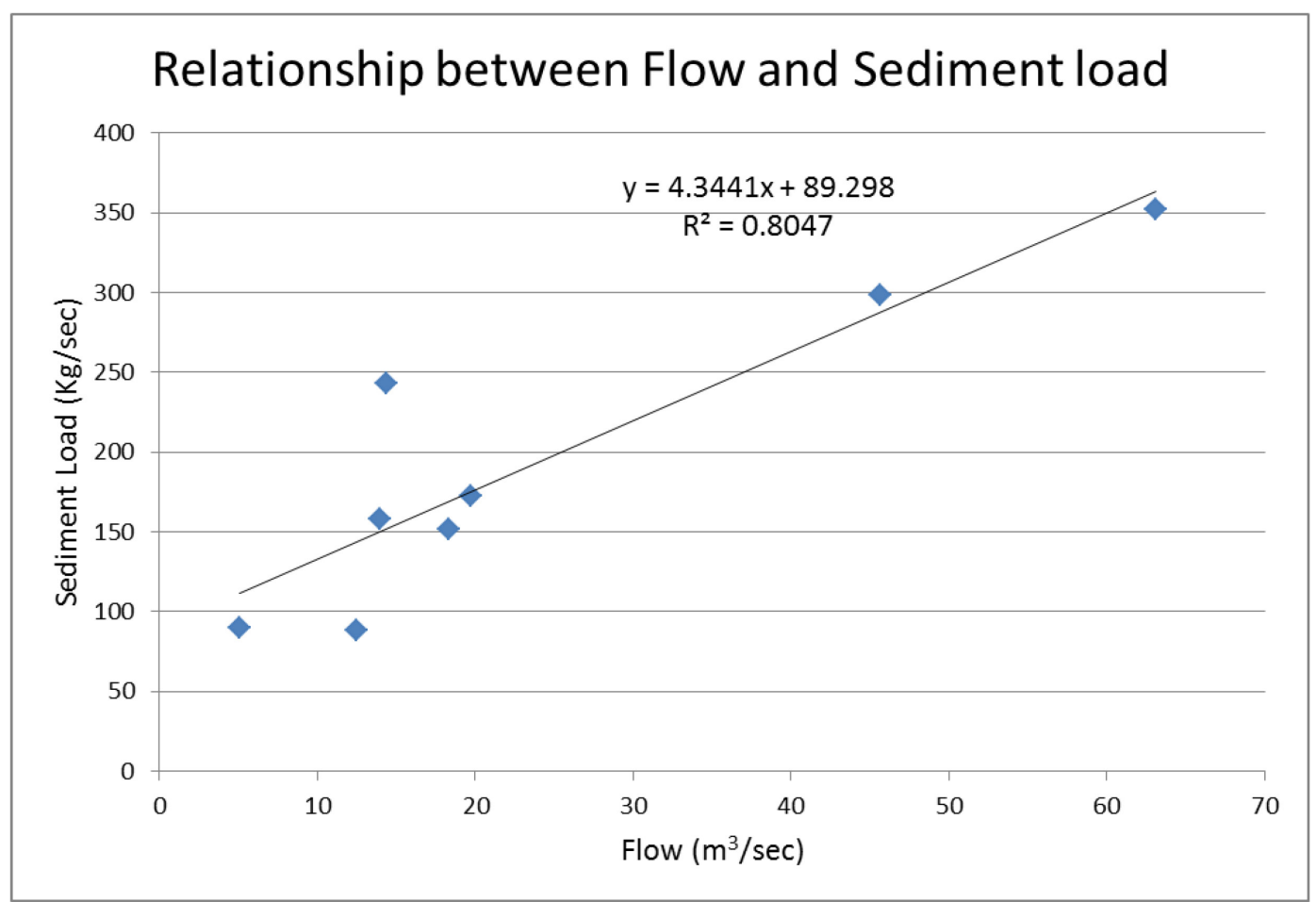

Figure 5.20. Sediments load and flows relationship in upper Ruvu catchment Rivers 
ML, MK and RK are downstream of Kibungo, Tawa, Kibogwa and Mfizigo and Ruvu Rivers. These rivers are passing through the forest reserve area while the cultivated upland is managed by agricultural management practices. Management practices in Kibungo sub-watershed include contour farming, strip cropping and mixed farming. Although sampling interval were weekly in four weeks, but the trends shows difference in results. The first week sampling shows high level of sediments in rivers because of some of final rains of rainy season in June and early July. Second through fourth samples were taken during July and early August which is within the dry season of the area. With no incoming runoff, streams has resulted unchanged levels of sediment. 


\subsection{CONCLUSION AND RECOMMENDATION}

\subsection{Conclusion}

The main objective of this study was to test the prediction capability of WEPP on tropical watersheds located in hillslope areas. The overall results indicated that WEPP model can assist watershed-related management institutions to quickly generate conservation zones by accepting predictions of sediment yield runoff outputs in spatially distributed format.

The results showed that hydrological outputs were quite well predicted. Average annual runoff depths predicted in all four sub-watersheds during the research period at different rainfall events varied from $0.46 \mathrm{~m}$ in lowlands within a high forest area (Kibungo chini) to $1.12 \mathrm{~m}$ in hillslope area, within open woodland and cultivated areas ( Mfizigo juu) sub-watershed. The highest total discharge at the watershed outlet was $3,462 \mathrm{~m}^{3} / \mathrm{s}$ on downstream sub-watershed that all streams join in the Kibungo chini sub watershed. The lowest total discharge at the watershed outlet was $135 \mathrm{~m}^{3} / \mathrm{s}$ at Mfizigo juu. Runoff also varied with soil type in all of the four watersheds. The maximum average annual runoff depths of $1.17 \mathrm{~m}$ estimated at areas with high percentage of Ferralic Cambisols and Humic Acrisols soils in Mfizigo juu sub-watershed. The minimum average annual runoff depth of $0.39 \mathrm{~m}$ was in areas with high percentage of Rhodic Ferralsols and Eutric Leptosols soil. Establishment of four physical scenarios setting at different conditions also predicted maximum average annual runoff depth to be $1.135 \mathrm{~m}$ at scenarios 1 and 2, while minimum average annual runoff depth was $0.051 \mathrm{~m}$ in areas with the same conditions of soil types. 
The maps locate only potential hotspots erosion areas with high sediments delivery which can help watershed and basin managers to implement necessary precautionary measures to minimize or prevent soil erosion. High hazard soil erosion spots appeared in high elevation areas of Tegetero, Kibogwa, Kibungo Juu, Tawa, Kinole and Mkuyuni wards in Mfizigo sub-watershed. Similarly, Mtombozi, Singisa, Kasanga and Kolero wards in Mvuha sub-watershed showed high vulnerability to soil loss. The watershed soil loss and sediment yield were correlated with runoff. The highest and lowest total average annual soil loss rates were estimated to be $45.09 \mathrm{~kg} / \mathrm{m}^{2}$ at Mfizigo juu watershed and at $0.45 \mathrm{~kg} / \mathrm{m}^{2}$ Kibungo chini watersheds, respectively. Although average total soil loss varied with runoff changes, the simulation showed some effect of soil type and slope in different land use/land covers within sub-watersheds. Model results show cultivated land contributes $81 \%$ of soil loss and $86 \%$ sediment yield in all four scenarios.

According to Walling (1994), sediment load represents a small percentage of the total land area eroded and converted to sediments but still is a good source of information for management of soil erosion and sedimentation within the basin. Better ability demonstrated by the WEPP model to predict soil erosion process in natural forest and bushland areas land use/land cover for the year period from 1990 to 2000. 


\subsection{Recommendation}

Although most studies conclude that WEPP model over predicts sediment yield and under estimates runoff but detail plot scale study in these four sub-watersheds is necessary to establish a long-term monitoring program and land use management practices. A detailed accurate prediction of sediment yield and runoff in Wami-Ruvu basin is crucial for planning and development of watershed based projects. The total suspended solids (TSS) results obtained during field study could not give good relationship with model output. This caused by the distance between the sampling locations and the watershed outlet for the WEPP simulation. Results from the field survey gave a very good visualization of sediment sources within the catchment. Current management practices in the catchment include contour farming, strip cropping, mulching and mixed farming. However, the present simulated model results could be in use for a further detailed study to validate using detailed inputs in different practices. 


\section{REFERENCES}

Adeogun B. K., Igboro S. B. and Ibrahim F. B. 2011. Estimate of bed load transport in Kubanni Watershed in Northern Nigeria using grain size distribution data. Water Resources and Environmental Engineering Vol. 3(5), pp. 102-108

Ascough, J.C., Baffaut, C., Nearing, M.A., Liu, B.Y. 1997. The WEPP watershed model: I. Hydrology and erosion. Transactions of the ASAE 40 (4): 921-933

Baigorria, G.A and Romero, C.C. 2007. Assessment of erosion hotspots in a watershed: Integrating the WEPP model and GIS in a case study in the Peruvian Andes. Environmental Modelling \& Software 22: 1175-1183

Beasley, D.B., Huggins, L.F. and Monke, E.J. 1980. ANSWERS: A model for Watershed Planning Transactions ASAE. 23(4): 938-944

Bhatia, Z., Buckley P. 1998. The Uluguru slopes planning project: Promoting Community involvement in biodiversity Conservation. East African Natural History. 87: 339-347.

Burgess, N.D., Butynski, T.M., Cordeiro, N.J., Doggart, N.H., Fjeldsa, J., K.M. Howell, Kilahama, F.B., Loaderk, S.P., Lovettl, J.C., Mbilinyia B., Menegonm, M.,. Moyern, D.C., Nashandaj, E.,Perking, A., Roverom, F., Stanleyo, W.T., Stuartp S.N., 2007. The biological importance of the Eastern Arc Mountains of Tanzania and Kenya. Biological Conservation 134: 209-231

Burgess, N.N., M. Nummelin, J. Fjeldså, K.M. Howell, K. Lukumbyzya, L. Mhando, P. Phillipson and Vanden Wege, J.P. (eds.) 1998a. Biodiversity and Conservation of the Eastern Arc Mountains in Tanzania and Kenya. Special Issue: Journal of the East African Natural History Society.87: 1-367.

Defersha M. 2010. Study of the Multi-Scale and Multi-Approach Investigation of Sediment Yield and Runoff Flux: The Mara River Basin, Kenya. MSc. Thesis at Florida International University, Department of Earth and Environment

De Roo, A.P.J., Hazelhoff, L. and Burrough, P.A. 1989. Soil Erosion modeling using ANSWERS and Geographical Systems. Earth Surface Processes and Landforms. 14: $517-532$

Dregne, H.E and Chou, N.T. 1994. Global desertification dimensions and costs. In: Degradation and Restoration of Arid Lands, ed. H.E. Dregne. Lubbock: Texas Technical University 
Elliot, W.J., Foltz, R.B. and Luce, C.H. 1995. Validation of Water Erosion Prediction Project (WEPP) Model for Low- Volume Forest Roads: Conference Proceedings. Volume I: In Sixth International Conference on Low-Volume Roads, Minneapolis, Minnesota. National Academy Press, Washington- DC

Elliot, W.J., G.R. Foster, A.V. Elliot. 1991. Soil Erosion: Processes, Impacts and Prediction, In Soil Management for Sustainability. Soil and Water Conservation Society, Ankeny, Iowa. p 25-34

Flanagan, D. C., Gilley, J. E., and Franti, T. G. 2007. Water Erosion Prediction Project (WEPP): Development history, model capabilities, and future enhancements. Trans. ASABE 50(5): 1603-1612

Foster, G.R and Lane., L.J. 1987. User requirements, USDA-water erosion prediction Project (WEPP) NSERL Report No. 1, National Soil Erosion Research Laboratory, West Lafayette, IN

Garde, R.J. and Raju, K.G.R. 2000. Mechanics of Sediment Transportation and Alluvial Stream Problems, New Age International (P) Ltd., New Delhi, India. pp 686

Hasan, M. K. and Alam, A. K. M. A. 2006. Land Degradation Situation in Bangladesh and Role of Agroforestry, Agriculture Rural Development, 4(1\&2): 19-25, ISSN $1810-1860$

Hillel, D.J. 1991. Out of the earth: Civilization and the life of the soil. The Free Press, New York.

J. de Vente, Poesen, J Verstraeten, G. Van Rompaey, A. Govers, G. (2008). Spatially distributed modelling of soil erosion and sediment yield at regional scales in Spain. Global and Planetary Change. (60) 393-415

Kaihura, F.B.S., I.K. Kullaya, M. Kilasara, J.B. Aune, B.R. Singh, R. Lal. 1999. Soil quality effects of accelerated erosion and management systems in three ecoregions of Tanzania/ Soil \& Tillage Research (53) 59 - 70

Kilahama, F.B.,Burgess, N.D., Lovettl, J.C.,Mhagama, S., 2004. Uluguru Biodiservisity Conservation and Sustainable Forest Management in Eastern Arc Mountains. Unpublished. Morogoro Tanzania

Kimaro, D. N., Poesen, J., Msanya, B. M. \& Deckers J. A. 2008. Magnitude of soil erosion on the northern slope of the Uluguru Mountsins, Tanzania. Interrill and rill erosion. Catena 75, 38-44, ISSN 0341-8162 
Knisel, W. G., Jr. 1980. CREAMS: A Field-scale Model for Chemicals, Runoff, and Erosion from Agricultural Management Systems. USDA-Conservation Research Report No. 26.

Kundzewicz, Z.W., L.J. Mata, N.W. Arnell, P. Döll, P. Kabat, B. Jiménez, K.A. Miller, T. Oki, Z. Sen and I.A. Shiklomanov, 2007: Freshwater resources and their management. Climate Change 2007: Impacts, Adaptation and Vulnerability. Contribution of Working Group II to the Fourth Assessment Report of the Intergovernmental Panel on Climate Change, M.L. Parry, O.F. Canziani, J.P. Palutikof, P.J. van der Linden and C.E. Hanson, Eds., Cambridge University Press, Cambridge, UK, 173-210

Lane, L. J. 1984. Surface Water Management: A User's Guide to Calculate a Water Balance Using the CREAMS Model. Los Alamos National Laboratory, Los Alamos, NM.

Lovett, J.C. \& S.K. Wasser (eds) 1993. Biogeography and Ecology of the Rain Forests of Eastern Africa. Cambridge University Press, Cambridge

Miller, S.N., Guertin, D.P., and Goodrich, D.C., 1996. Linking GIS and geomorphology field research at Walnut Gulch. Proceedings of the AWRA 32nd Annual Conference and Symposium: "GIS and Water Resources”, Sept. 22-26, 1996, Ft. Lauderdale, FL.

Miller, S.N., Semmens, D.J., Miller, R.C., Hernandez, M., Miller, W.P., Goodrich, D.C., Kepner, W.G., Ebert, D., 2002. GIS-based hydrologic modeling: The Automated Geospatial Watershed Assessment Tool. Proc. 2nd Federal Interagency Conf. on Hydrologic Modeling,July 29-Aug. 1, Las Vegas, NV

Minkowski, M., and Renschler, C. GeoWEPP for ArcGIS 9.x Full Version Manual. Retrieved from:

http://www.geog.buffalo.edu/ rensch/geowepp/arcgeowepp/GeoWEPP $\% 20$ for $\% 2$ 0ArcGIS\%209\%20Manual.pdf

Morgan, R.P.C. 1995. Soil Erosion and Conservation, 2nd Edition. Longman Group Unlimited. London, U.K. pp. 198

Ndomba, P.M. 2010. Modelling of Sedimentation Upstream of Nyumba ya Mungu Reservoir in Pangani River Basin. Nile Basin Water Science\& Engineering Journal, Vol.3, Issue2, 2010

Ndomba, P.M., Mtalo, F. \& Killingtveit, A. 2007. A Proposed Approach of Sediment Sources and Erosion Processes Identification at Large Catchments. Journal of Urban and Environmental Engineering, V.1, n.2: 79-86. ISSN 1982-3932 
Nearing, M.A., Foster, G.R., and Finkner, S.C. 1989. A Process-Based Soil Erosion Model for USDA - Water Erosion Prediction Project Technology: Trans. ASABE 32(5): 1587-1593

Ngana, J., Mahay, F., Cross, K., 2010a. Ruvu Basin: A Situational Analysis. IUCNESARO Publications Services Unit. Nairobi, Kenya

Ngana, J., Mahay, F., Cross, K., 2010b. Wami Basin: A Situational Analysis. IUCNESARO Publications Services Unit. Nairobi, Kenya.

Ngoye, E., and Machiwa, J.F. 2004. The influence of land-use patterns in the Ruvu river watershed on water quality in the river system. Physics and Chemistry of the Earth. 29:1161-1166

Nyhan, J. W., and L. J. Lane. 1982. Use of a State of the Art Model in Generic Designs of Shallow Land Repositories for Low-Level Wastes. In Waste Management '82 (R. G. Post and M. E. Wacks, Eds.), University of Arizona, Tucson

Nyssen, J., Poesen, J., Deckers, J. 2009. Land degradation and soil and water conservation in tropical highlands. Soil \& Tillage Research (103) 197-202

Poynton, J.C., Howell, K.M., Clarke, B.T. \& Lovett, J.C. 1998. A critically endangered new species of Nectophrynoides (Anura: Bufonidae) from the Udzungwa mountains, Tanzania. African Journal of Herpetology 47(2): 59-67.

Ongley., E. D.1996. Control of water pollution from agriculture: FAO irrigation and drainage paper 55, Food and Agriculture Organization of the United Nations: Rome

Pepper, D.A., G.W. Stone and P. Wang. 1999. Bottom boundary layer parameters and sediment transport on the Louisiana inner-shelf during cold front passages. Transactions of the Gulf Coast Association Geological Societies, 49: pp. 432-439

Pimentel, D., C. Harvey, P. Resosudarmo, K. Sinclair, D. Kurz, M. McNair, S. Crist, L. Shpritz, L. Fitton, R. Saffouri, and R. Blair. (1995). Environmental and economic costs of soil erosion and conservation benefits. Science. 267: 1117-1123.

Prosser, I.P., Rutherford, I.D., Olley, J.M., Young, W.J., Wallbrink, P. J., Moran, C.J. 2001. Large-scale patterns of erosion and sediment transport in river networks, with examples from Australia. Marine and Freshwater Research 52, 81-99

Rapp, A., L. Berry and P. Temple 1973. Studies of soil erosion and sedimentation in Tanzania. BRALUP Research Monograph Number 1, 1973. Dar es Salaam: Bureau of Resource Assessment and Land Use Planning, University of Dar es 
Salaam. Published in association with the Swedish Society of Anthropology and Geography, distributed internationally as Geografiska Annaler, 54A, 3-4, 1972.

Renard, K.G., G.R. Foster, G.A. Weesies, D.K. McCool, and D.C. Yoder coordinators. 1997. Predicting Soil Erosion by Water: A Guide to Conservation Planning with the Revised Universal Soil Loss Equation (RUSLE). U.S. Department of Agriculture, Agricultural Handbook

Scheele, D.L; Elliot, W.J.; Hall, D.E. 2001. Enhancements to the CLIGEN Weather Generator for Mountainous or Custom Applications. In: J.C. Ascough II and D.C. Flanagan, eds., Soil Erosion Research for the 21st Century, Proc. Int. Symp. (3-5 January 2001, Honolulu, HI, USA). St. Joseph, MI: ASAE. pp. 392-395

Sharma, N., T. Damhang, E. Gilgan-Hunt, D. Grey, V. Okaru, and D. Rothberg, (1996). African Water Resources: Challenges and Opportunities for Sustainable Development. World Bank Technical Paper No. 33, African Technical Department Series, The World Bank, Washington DC, USA

Temple, P.H. 1972. Soil and Water Conservation Policies in the Uluguru Mountains, Tanzania. Department of Geography, University of Dar es Salaam. Published in association with the Swedish Society of Anthropology and Geography, distributed internationally as Geografiska Annaler, 54A, 110-123.

URT (United Republic of Tanzania). 2011. Morogoro District Profile, Prime Minister's Office: Ministry of Regional Administration and Local Government: Morogoro, Tanzania

US Department of Agriculture (USDA). 2000. Summary Report: National Resources Inventory. Natural Resources Conservation Service, Washington, DC, and Statistical Laboratory, Iowa State University, Ames, Iowa. 89 p

Walling, D. E. 1999. Linking land use, erosion and sediment yields in river basins. Hydrobiologia, 410: 223-240

Walling, D.E. 1994. Measuring sediment yield from river basins. In: Lal, R. Soil Erosion Research Methods. 2nd ed. Soil and Water Conservation Society, Ankeny, IA, USA, pp. $39-80$

Wami/Ruvu Basin Office, 2010. Progress Report http://wamiruvubasin.com/Reports.html

Williams, J.R. and D.L. Tanaka. 1996. Economic evaluation of topsoil loss in spring wheat production in the northern Great Plains, USA. Soil and Till Res. 37: 95112 . 
Yanda, P. Z., Munishi, P. K. T. 2007. Hydrologic and Land Use/Cover Change Analysis for the Ruvu River (Uluguru) and Sigi River (East Usambara) Watershed.

Unpublished report submitted to WWF/CARE Dar es Salaam, Tanzania

Young, R.A., Onstad, C.A., Bosch, D.D., Anderson, W.P. 1989. AGNPS: a nonpointsource pollution model for evaluating agricultural watersheds. Soil and Water Conservation. 44 (2): 168-173

Young, W.J., Olley, J.M., Prosser, I.P., Warner, R.F. 2001. Relative changes in sediment supply and sediment transport capacity in a bedrock-controlled river. Water Resources Research 37, 3307-3320 


\section{APPENDICES}

\section{Appendix I: Mfizigo Juu sub-watershed model summary output}

\begin{tabular}{|c|c|c|c|c|c|c|c|c|c|}
\hline \multirow{2}{*}{$\begin{array}{c}\text { Land } \\
\text { Use/Cover } \\
\text { Description }\end{array}$} & \multirow{2}{*}{$\begin{array}{c}\text { Coverage } \\
\text { Area } \\
\left(\mathbf{m}^{2}\right)\end{array}$} & \multicolumn{2}{|c|}{ Runoff } & \multicolumn{2}{|c|}{ Soil Loss } & \multicolumn{2}{|c|}{ Sediment Deposition } & \multicolumn{2}{|c|}{ Sediment Yield } \\
\hline & & $\begin{array}{l}\text { Volume } \\
\left(\mathrm{m}^{3}\right)\end{array}$ & Depth (m) & Total (kg) & $\begin{array}{c}\text { Rate } \\
\left(\mathrm{kg} / \mathrm{m}^{2}\right)\end{array}$ & Total (kg) & $\begin{array}{c}\text { Rate } \\
\left(\mathrm{kg} / \mathrm{m}^{2}\right)\end{array}$ & Total (kg) & $\begin{array}{c}\text { Rate } \\
\left(\mathrm{kg} / \mathrm{m}^{2}\right)\end{array}$ \\
\hline $\begin{array}{l}\text { Fallow- } \\
\text { Tilled }\end{array}$ & 3996000 & 5929555.41 & 1.48387273 & 12864685.15 & 3.21939068 & 0 & 0 & 418004810.3 & 104.60581 \\
\hline $\begin{array}{l}\text { Tall Grass } \\
\text { Prairie }\end{array}$ & 125667900 & 150176103.1 & 1.19502357 & 4250761332 & 33.825355 & 69650784.64 & 0.554244836 & 4181111062 & 33.271114 \\
\hline $\begin{array}{l}\text { Short Grass } \\
\text { Prairie }\end{array}$ & 1071000 & 1455892.37 & 1.35937663 & 22291697.57 & 20.81391 & 165287.77 & 0.154330317 & 22126413.33 & 20.659583 \\
\hline Fire-LSEY & 331267500 & 419809380.4 & 1.26728212 & 10424103702 & 31.4673299 & 88794668.59 & 0.268045216 & 10335311703 & 31.199293 \\
\hline $\begin{array}{l}\text { Shrub- } \\
\text { Perennial }\end{array}$ & 114408000 & 115249811.8 & 1.00735798 & 189416851.3 & 1.65562593 & 18851499.6 & 0.164774313 & 170566067.9 & 1.4908579 \\
\hline Forest & 210238200 & 196099946.1 & 0.93275126 & 1769976713 & 8.41891109 & 45233535.52 & 0.215153742 & 1724746795 & 8.2037746 \\
\hline $\begin{array}{l}\text { Forest- } \\
\text { Perennial } \\
(5 Y R)\end{array}$ & 23417100 & 23554469.44 & 1.0058662 & 10859884.68 & 0.46375874 & 355275.68 & 0.015171634 & 10504627.88 & 0.4485879 \\
\hline
\end{tabular}

\begin{tabular}{|c|c|c|c|c|c|c|c|c|c|}
\hline \multirow{2}{*}{$\begin{array}{c}\text { Soil } \\
\text { Description }\end{array}$} & \multirow{2}{*}{$\begin{array}{l}\text { Coverage } \\
\text { Area }\left(\mathbf{m}^{2}\right)\end{array}$} & \multicolumn{2}{|c|}{ Runoff } & \multicolumn{2}{|c|}{ Soil Loss } & \multicolumn{2}{|c|}{ Sediment Deposition } & \multicolumn{2}{|c|}{ Sediment Yield } \\
\hline & & $\begin{array}{l}\text { Volume } \\
\left(\mathrm{m}^{3}\right)\end{array}$ & Depth (m) & Total (kg) & $\begin{array}{c}\text { Rate } \\
\left(\mathrm{kg} / \mathrm{m}^{2}\right)\end{array}$ & Total (kg) & $\begin{array}{c}\text { Rate } \\
\left(\mathrm{kg} / \mathrm{m}^{2}\right)\end{array}$ & Total (kg) & $\begin{array}{c}\text { Rate } \\
\left(\mathrm{kg} / \mathrm{m}^{2}\right)\end{array}$ \\
\hline $\begin{array}{l}\text { Shrub - Silt } \\
\text { Loam }\end{array}$ & 114103800 & 117570083.5 & 1.03037834 & 807851983.9 & 7.07997441 & 46088932.75 & 0.403921103 & 761765392.1 & 6.6760738 \\
\hline $\begin{array}{l}\text { Forest-Clay } \\
\text { Loam }\end{array}$ & 277991100 & 325708716 & 1.1716516 & 5595321626 & 20.1277006 & 104533750.3 & 0.376032723 & 5895929131 & 21.209057 \\
\hline $\begin{array}{l}\text { YF-Clay } \\
\text { Loam }\end{array}$ & 275565600 & 308348372.7 & 1.1189654 & 8640665243 & 31.3561099 & 30661844.55 & 0.111268767 & 8610004717 & 31.244846 \\
\hline $\begin{array}{l}\text { Forest-Silt } \\
\text { Loam }\end{array}$ & 142405200 & 160647986.3 & 1.12810478 & 1636436013 & 11.4914063 & 41766524.18 & 0.293293533 & 1594672238 & 11.198132 \\
\hline
\end{tabular}


Appendix II: Mvuha Juu sub-watershed model summary output

\begin{tabular}{|c|c|c|c|c|c|c|c|c|c|}
\hline \multirow{2}{*}{$\begin{array}{c}\text { Land } \\
\text { Use/Cover } \\
\text { Description }\end{array}$} & \multirow{2}{*}{$\begin{array}{l}\text { Coverage } \\
\text { Area }\left(\mathbf{m}^{2}\right)\end{array}$} & \multicolumn{2}{|c|}{ Runoff } & \multicolumn{2}{|c|}{ Soil Loss } & \multicolumn{2}{|c|}{ Sediment Deposition } & \multicolumn{2}{|c|}{ Sediment Yield } \\
\hline & & Volume $\left(\mathrm{m}^{3}\right)$ & Depth (m) & Total (kg) & $\begin{array}{c}\text { Rate } \\
\left(\mathrm{kg} / \mathrm{m}^{2}\right)\end{array}$ & Total (kg) & $\begin{array}{c}\text { Rate } \\
\left(\mathrm{kg} / \mathrm{m}^{2}\right)\end{array}$ & Total (kg) & Rate $\left(\mathrm{kg} / \mathrm{m}^{2}\right)$ \\
\hline Fallow-Tilled & 20893500 & 25976979.11 & 1.24330433 & 321426396.6 & 15.38403794 & 49018044.5 & 2.34609063 & 272408349 & 13.03794716 \\
\hline Tall Grass Prairie & 73935000 & 71911993.58 & 0.97263804 & 1409939083 & 19.06998151 & 79497044.3 & 1.07522884 & 1330442412 & 17.99475772 \\
\hline $\begin{array}{l}\text { Corn, soybean - } \\
\text { SCP }\end{array}$ & 8397000 & 9115830.43 & 1.08560562 & 45329343.66 & 5.398278392 & 13526588.7 & 1.6108835 & 31802806.96 & 3.787401091 \\
\hline Fire-LSEY & 186876900 & 179744545.2 & 0.96183394 & 4525065123 & 24.21414912 & 169222834 & 0.90553104 & 4355842829 & 23.30862097 \\
\hline Shrub-Perennial & 39645900 & 29013951.28 & 0.73182728 & 362543243.3 & 9.144533062 & 1023000.4 & 0.02580343 & 361520108.2 & 9.118726228 \\
\hline Forest & 38468700 & 26900677.53 & 0.69928741 & 370745319.6 & 9.637583791 & 1019021.55 & 0.02648963 & 369726268.2 & 9.611093387 \\
\hline
\end{tabular}

\begin{tabular}{|c|c|c|c|c|c|c|c|c|c|}
\hline \multirow[t]{2}{*}{ Soil Description } & \multirow{2}{*}{$\begin{array}{l}\text { Coverage } \\
\text { Area }\left(\mathbf{m}^{2}\right)\end{array}$} & \multicolumn{2}{|c|}{ Runoff } & \multicolumn{2}{|c|}{ Soil Loss } & \multicolumn{2}{|c|}{ Sediment Deposition } & \multicolumn{2}{|c|}{ Sediment Yield } \\
\hline & & $\begin{array}{l}\text { Volume } \\
\left(\mathrm{m}^{3}\right)\end{array}$ & Depth (m) & Total (kg) & $\begin{array}{c}\text { Rate } \\
\left(\mathrm{kg} / \mathrm{m}^{2}\right)\end{array}$ & Total (kg) & $\begin{array}{c}\text { Rate } \\
\left(\mathrm{kg} / \mathrm{m}^{2}\right)\end{array}$ & Total (kg) & Rate $\left(\mathrm{kg} / \mathrm{m}^{2}\right)$ \\
\hline LSF-Clay Loam & 14210100 & 15855583.04 & 1.11579672 & 82044870.74 & 5.773701152 & 0 & 0 & 0 & 0 \\
\hline Forest-Clay Loam & 152665200 & 163344196.9 & 1.06995043 & 1958885629 & 12.83125184 & 107193781 & 0.70214941 & 1851692242 & 12.12910501 \\
\hline YF-Sandy Loam & 73611900 & 58760536.99 & 0.7982478 & 2013570273 & 27.35386905 & 86277632.1 & 1.17206093 & 1927292948 & 26.18181229 \\
\hline YF-Clay Loam & 118432800 & 96438249.96 & 0.81428667 & 2715071420 & 22.92499561 & 89931044.2 & 0.75934238 & 2625140043 & 22.16565042 \\
\hline Forest-Silt Loam & 9297000 & 8265410.18 & 0.88904057 & 265476316.2 & 28.55505176 & 2269062.89 & 0.24406399 & 263207649.8 & 28.31103042 \\
\hline
\end{tabular}


Appendix III: Msumbizi sub-watershed model summary output

\begin{tabular}{|c|c|c|c|c|c|c|c|c|c|}
\hline \multirow{2}{*}{$\begin{array}{l}\text { Land Use/Cover } \\
\text { Description }\end{array}$} & \multirow{2}{*}{$\begin{array}{l}\text { Coverage } \\
\text { Area }\left(\mathbf{m}^{2}\right)\end{array}$} & \multicolumn{2}{|c|}{ Runoff } & \multicolumn{2}{|c|}{ Soil Loss } & \multicolumn{2}{|c|}{ Sediment Deposition } & \multicolumn{2}{|c|}{ Sediment Yield } \\
\hline & & $\begin{array}{l}\text { Volume } \\
\left(\mathrm{m}^{3}\right)\end{array}$ & Depth (m) & Total (kg) & $\begin{array}{c}\text { Rate } \\
\left(\mathrm{kg} / \mathrm{m}^{2}\right)\end{array}$ & Total (kg) & $\begin{array}{c}\text { Rate } \\
\left(\mathrm{kg} / \mathrm{m}^{2}\right)\end{array}$ & Total (kg) & $\begin{array}{c}\text { Rate } \\
\left(\mathrm{kg} / \mathrm{m}^{2}\right)\end{array}$ \\
\hline Fallow-Tilled & 2049300 & 2133460.14 & 1.04106775 & 23077236 & 11.2610335 & 80272.63 & 0.039170756 & 22996962.52 & 11.221862 \\
\hline Tall Grass Prairie & 50476500 & 35584856.19 & 0.70497868 & 45454119 & 0.9005006 & 7458990.07 & 0.147771539 & 37995274.76 & 0.752732 \\
\hline Fire-LSEY & 25162200 & 21618757.51 & 0.85917597 & 196878173 & 7.82436245 & 12020488.96 & 0.47772011 & 184857620.4 & 7.3466398 \\
\hline Shrub-Perennial & 1511100 & 797876.24 & 0.52801022 & 600465.42 & 0.39736974 & 297.43 & 0.00019683 & 600168.78 & 0.3971734 \\
\hline Forest & 33978600 & 14962196.54 & 0.44034176 & 109099962 & 3.21084335 & 2525232.53 & 0.074318322 & 106574754.5 & 3.1365258 \\
\hline $\begin{array}{l}\text { Forest-Perennial } \\
(5 \mathrm{YR})\end{array}$ & 98688600 & 45605481.55 & 0.46211499 & 32379820 & 0.32810092 & 1014994.99 & 0.010284825 & 31364902.48 & 0.3178169 \\
\hline
\end{tabular}

\begin{tabular}{|c|c|c|c|c|c|c|c|c|c|}
\hline \multirow[t]{2}{*}{ Soil Description } & \multirow{2}{*}{$\begin{array}{l}\text { Coverage } \\
\text { Area }\left(\mathrm{m}^{2}\right)\end{array}$} & \multicolumn{2}{|c|}{ Runoff } & \multicolumn{2}{|c|}{ Soil Loss } & \multicolumn{2}{|c|}{ Sediment Deposition } & \multicolumn{2}{|c|}{ Sediment Yield } \\
\hline & & $\begin{array}{l}\text { Volume } \\
\left(\mathrm{m}^{3}\right)\end{array}$ & Depth (m) & Total (kg) & $\begin{array}{c}\text { Rate } \\
\left(\mathrm{kg} / \mathrm{m}^{2}\right)\end{array}$ & Total (kg) & $\begin{array}{c}\text { Rate } \\
\left(\mathrm{kg} / \mathrm{m}^{2}\right)\end{array}$ & Total (kg) & $\begin{array}{c}\text { Rate } \\
\left(\mathrm{kg} / \mathrm{m}^{2}\right)\end{array}$ \\
\hline Shrub - Silt Loam & 547200 & 213731.37 & 0.39059095 & 6573189 & 12.0124067 & 7.76 & $1.41813 \mathrm{E}-05$ & 6573197.83 & 12.012423 \\
\hline Forest-Clay Loam & 200000700 & 114748337.6 & 0.57373968 & 397931300 & 1.98964953 & 23049223.55 & 0.115245714 & 374882239.9 & 1.8744046 \\
\hline Forest-Silt Loam & 11318400 & 5740559.25 & 0.50718823 & 2985286.3 & 0.26375515 & 51045.3 & 0.00450994 & 2934245.65 & 0.2592456 \\
\hline
\end{tabular}


Appendix IV: Kibungo chini sub-watershed model output

\begin{tabular}{|c|c|c|c|c|c|c|c|c|c|}
\hline \multirow{2}{*}{$\begin{array}{c}\text { Land } \\
\text { Use/Cover } \\
\text { Description }\end{array}$} & \multirow{2}{*}{$\begin{array}{l}\text { Coverage } \\
\text { Area }\left(\mathbf{m}^{2}\right)\end{array}$} & \multicolumn{2}{|c|}{ Runoff } & \multicolumn{2}{|c|}{ Soil Loss } & \multicolumn{2}{|c|}{ Sediment Deposition } & \multicolumn{2}{|c|}{ Sediment Yield } \\
\hline & & $\begin{array}{l}\text { Volume } \\
\left(\mathrm{m}^{3}\right)\end{array}$ & Depth (m) & Total (kg) & $\begin{array}{c}\text { Rate } \\
\left(\mathrm{kg} / \mathrm{m}^{2}\right)\end{array}$ & Total (kg) & $\begin{array}{c}\text { Rate } \\
\left(\mathrm{kg} / \mathrm{m}^{2}\right)\end{array}$ & Total (kg) & $\begin{array}{c}\text { Rate } \\
\left(\mathrm{kg} / \mathrm{m}^{2}\right)\end{array}$ \\
\hline $\begin{array}{l}\text { Fallow Tilled } \\
0.5 \% \text { Contours }\end{array}$ & 2605500 & 1578280.18 & 0.605749445 & 4369666.52 & 1.67709327 & 0 & 0 & 85486643.56 & 32.81007237 \\
\hline $\begin{array}{l}\text { Tall Grass } \\
\text { Prairie } \\
\end{array}$ & 792000 & 214444.14 & 0.270762803 & 433483.23 & 0.54732731 & 32815.61 & 0.041433851 & 400668 & 0.505893939 \\
\hline Fire-LSEY & 51292800 & 23285804.85 & 0.453978041 & 20058317.68 & 0.39105523 & 4681765.44 & 0.091275295 & 15376822.64 & 0.299785207 \\
\hline
\end{tabular}

\begin{tabular}{|c|c|c|c|c|c|c|c|c|c|}
\hline \multirow{2}{*}{$\begin{array}{c}\text { Soil } \\
\text { Description }\end{array}$} & \multirow{2}{*}{$\begin{array}{l}\text { Coverage } \\
\text { Area }\left(\mathbf{m}^{2}\right)\end{array}$} & \multicolumn{2}{|c|}{ Runoff } & \multicolumn{2}{|c|}{ Soil Loss } & \multicolumn{2}{|c|}{ Sediment Deposition } & \multicolumn{2}{|c|}{ Sediment Yield } \\
\hline & & $\begin{array}{l}\text { Volume } \\
\left(\mathrm{m}^{3}\right)\end{array}$ & Depth (m) & Total (kg) & $\begin{array}{c}\text { Rate } \\
\left(\mathrm{kg} / \mathrm{m}^{2}\right)\end{array}$ & Total $(\mathrm{kg})$ & $\begin{array}{c}\text { Rate } \\
\left(\mathrm{kg} / \mathrm{m}^{2}\right)\end{array}$ & Total $(\mathrm{kg})$ & $\begin{array}{c}\text { Rate } \\
\left(\mathrm{kg} / \mathrm{m}^{2}\right)\end{array}$ \\
\hline $\begin{array}{l}\text { Forest-Clay } \\
\text { Loam }\end{array}$ & 7605900 & 3653993.94 & 0.480415722 & 2000712.01 & 0.26304737 & 246757.55 & 0.032442913 & 1753957.99 & 0.230604924 \\
\hline $\begin{array}{l}\text { HSF-Clay } \\
\text { Loam }\end{array}$ & 15766200 & 7662729.27 & 0.486022584 & 11142954.55 & 0.70676222 & 3714613.16 & 0.235606117 & 88545322.73 & 5.616148643 \\
\hline $\begin{array}{l}\text { Forest-Silt } \\
\text { Loam }\end{array}$ & 31318200 & 13761805.96 & 0.439418803 & 11717800.87 & 0.37415308 & 753210.34 & 0.024050244 & 10964853.48 & 0.350111229 \\
\hline
\end{tabular}

\begin{tabular}{|l|l|}
\hline KEY & DESCRIPTION \\
\hline Land Use/Cover & \\
\hline Corn, soybean - SCP & $\begin{array}{l}\text { Corn, soybean - Spring Chisel } \\
\text { Plow }\end{array}$ \\
\hline Fire-LSEY & Fire - Low Severity Every Year \\
\hline
\end{tabular}

\begin{tabular}{|l|l|}
\hline KEY & DESCRIPTION \\
\hline Soil & \\
\hline LSF-Clay Loam & Low Severity Fire - Clay Loam \\
\hline YF-Sandy Loam & Young Forest-Sandy Loam \\
\hline YF-Clay Loam & Young Forest-Clay Loam \\
\hline HSF-Clay Loam & High Severity Fire-Clay Loam \\
\hline
\end{tabular}




\section{Appendix V: WEPP model output format}

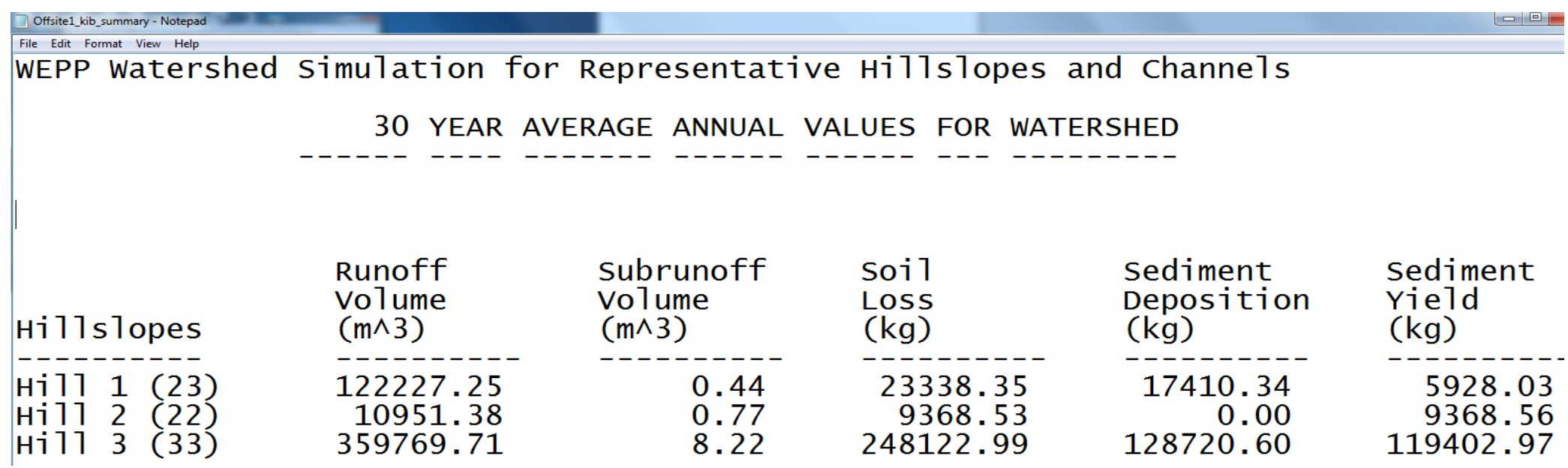

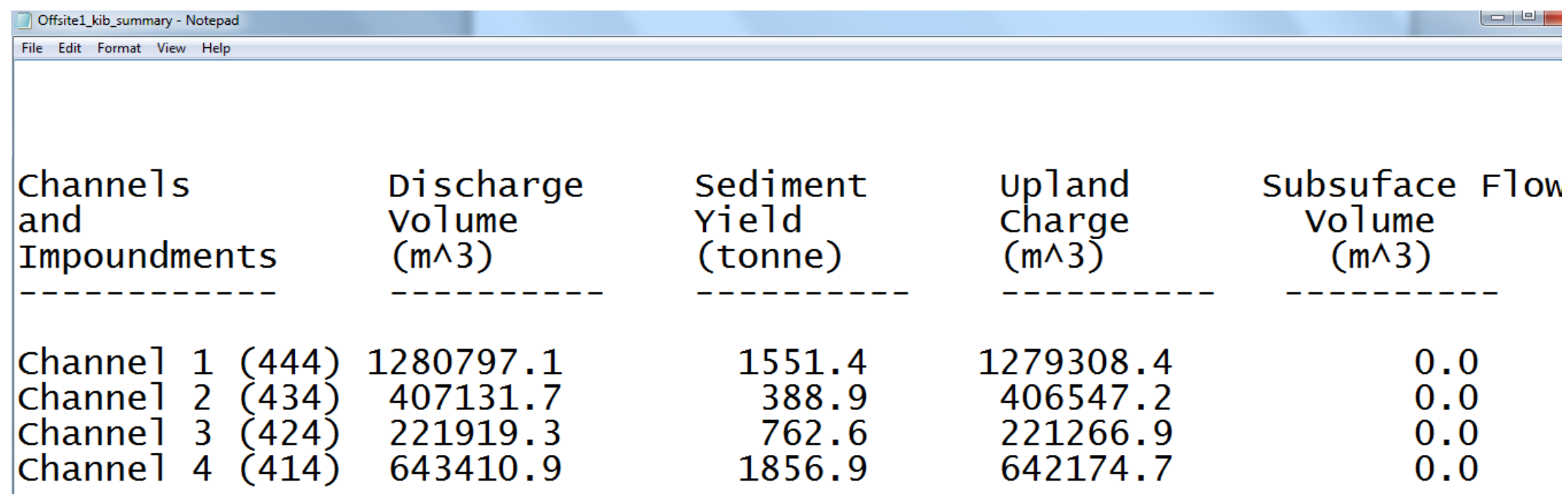

